\title{
DIVERSIFICAÇÃO COMO FORMA DE GERENCIAMENTO DE RISCO NA AGRICULTURA
}

\author{
SERGIO De ZeN \\ Engenheiro Agrônomo \\ Orientador: Prof. Dr. GERALDO SANT'ANA DE CAMARGO BARROS \\ Tese apresentada à Escola \\ Superior de Agricultura "Luiz de \\ Queiroz", Universidade de São \\ Paulo, para obtenção do título de \\ Doutor em Ciências, Área de \\ Concentração: Economia Aplicada
}

PIRACICABA

Estado de São Paulo - Brasil

Fevereiro - 2002 


\section{Dados Internacionais de Catalogação na Publicação (CIP) DIVISĀO DE BIBLIOTECA E DOCUMENTAÇÃO - ESALQ/USP}

\section{De Zen, Sérgio}

Diversificação como forma de gerenciamento de risco na agricultura / Sérgio De Zen.

- Piracicaba, 2002.

$107 \mathrm{p}$.

Tese (doutorado) - Escola Superior de Agricultura buiz de Queiroz, 2002.

Bibliografia.

1. Administração de risco 2. Economia agrícola 3. Produtor rural 4. Renda agricola I. Titulo

CDD 338.1 
Aos meus pais,

Ugo e Brígida,

Ofereço.

À minha esposa,

Maria José,

dedico. 


\section{AGRADECIMENTOS}

Aỏ Centro de Estudos Avançados em Economia Aplicada pela oportunidade, formação pessoal e profissional, pelos dados e apoio financeiro que possibilitaram este doutoramento. Esta casa é um exemplo de colaboração entre companheiros, pois é possível sentir que as pessoas crescem em conjunto e as suas vitórias significam a realização de um grupo.

Ao Departamento de Economia, Sociologia e Administração da Escola Superior de Agricultura Luiz de Queiroz pela formação acadêmica.

Aos amigos e colegas, em especial a Maria Aparecida S. B. Motta, Margarete Boteon, Ana Paula Silva, Augusto Gameiro, Paulo Martins, Ricardo Lopes, Alexandre Nunes e Silvia Miranda que ao longo de todo o período deram apoio e incentivo voluntários.

Ao meu orientador, Professor Geraldo Sant'Ana de Camargo Barros, que foi muito além do seu papel de orientador. Trata-se de um exemplo de caráter e retidão na orientação para a vida e na condução de pesquisas.

Ao professor Fernando Curi Peres pela paciência de indicar caminhos e passar conhecimento de forma desinteressada e competente, sem os quais não teria chegado ao fim deste trabalho. 
À professora Mirian Rumenos Piedade Bacchi pelo exemplo de trabalho e apoio. Além disto, é um referencial de equilíbrio e competência para todas as pessoas que tenham vontade de semear o bem. A retidão de caráter, atestada ao longo de seis anos na condição de colega e aluno, faz-me orgulhoso por ter recebido suas valiosas contribuições a este trabalho e à vida.

Aos professores Joaquim Bento de Souza Filho e José Vicente Caixeta Filho pelas orientações objetivas.

Agradeço aos colegas do CEPEA que contribuíram nos momentos em que estava ausente, em aula e viagens de coleta de dados. Ao amigo Valter Galan que foi um companheiro essencial no trabalho de coleta de dados nos locais mais distantes do Mato Grosso. Aos colegas Leandro Ponchio e Tiago Barata pelo companheirismo no Rio Grande do Sul, nos levantamento e tabulação de dados. À professora Heloisa Lee Burnquist pelo apoio em projetos que permitiram a realização de pesquisas no Rio Grande do Sul.

Agradeço aos meus pais, Ugo e Brígida, que me deram tudo nesta vida. Agradeço à minha esposa Maria José que teve paciência e equilíbrio nas situações difíceis, enfim, foi a companheira de todos os momentos. Agradeço a Deus por ter concluído este trabalho. 


\section{SUMÁRIO}

Página

LISTA DE FIGURAS …......................................................................... viii

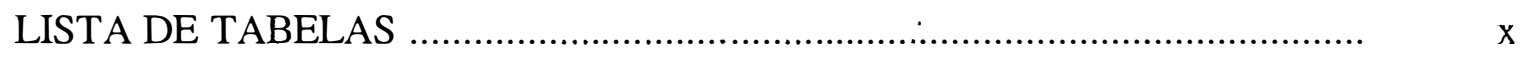

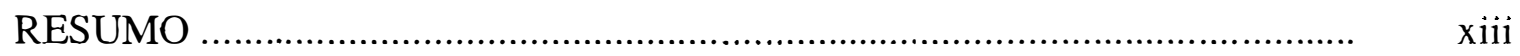

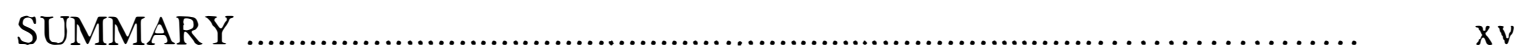

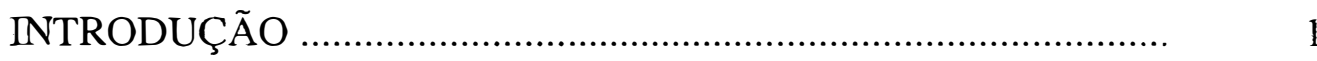

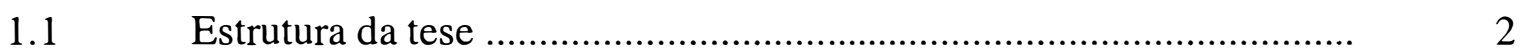

$1.2 \quad$ Políticas públicas para o setor agrícola.................................................

1.2.1 Esgotamento do Sistema de Crédito Oficial e alternativas públicas de

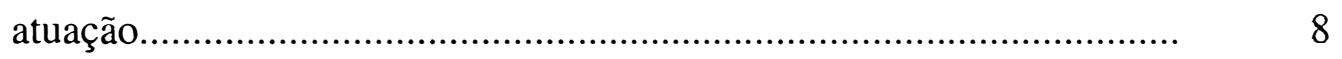

1.2.2 Alternativas Estatais de Crédito e Gerenciamento de Riscos de

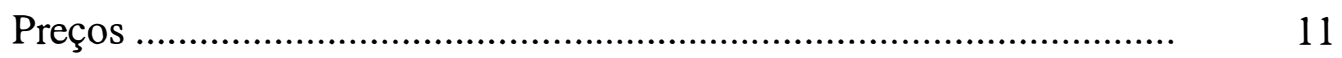

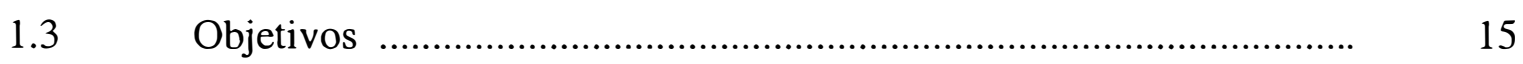

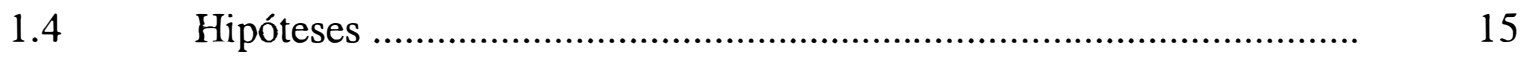

2 REVISÃO DE LITERATURA _.................................................... 16

$3 \quad$ Fontes de Dados.............................................................................. 21

3.1 Painel Agrícola ............................................................................ 22

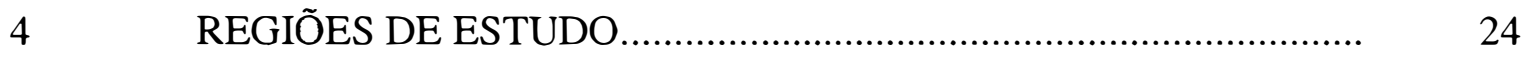

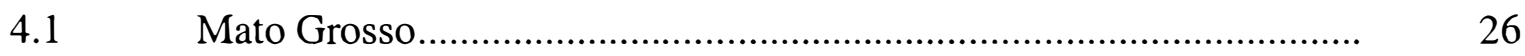

4.1.1 Mato Grosso no Cenário Nacional...................................................... 29

4.1.2 Descrição regional ........................................................................ 30

4.1.3 Propriedades Típicas ..................................................................... 34

4.1.4 Fluxo de Caixa da Propriedade.......................................................... 39 


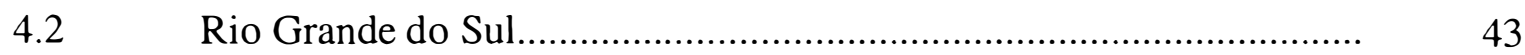

4.2.1 Região de Carazinho - RS................................................................ 45

4.2.2 Propriedades Típicas...................................................................... 46

4.2.3 Fluxo de Caixa da Propriedade.......................................................... 48

$5 \quad$ METODOLOGIA _................................................................... 51

5.1 Descrição do Modelo ........................................................................ 51

5.2 Modelos de Otimização em Condições de Risco ................................. 52

$6 \quad$ RESULTADOS E DISCUSSÃO ……......................................... 59

6.1 Relações entre a receita bruta das diversas culturas ............................ 59

6.2 Mato Grosso .................................................................................. 60

6.2.1 Desvios absolutos da receita bruta: medida linear de risco ................. 64

6.2.2 Modelos com a inclusão de risco......................................................... 68

6.3 Rio Grande do Sul................................................................. 72

6.3.1 Desvios absolutos da receita bruta: medida linear de riscos ............... 75

6.3.2 Limitações do modelo ................................................................... 79

6.3.3 Modelo Quadrático .................................................................... 80

6.4 Resultados do Mato Grosso …………........................................... 80

6.5 Resultados do Rio Grande do Sul................................................. 85

6.6 Fronteiras Eficientes................................................................. 90

6.7 Taxa de Aversão ao Risco.............................................................. 93

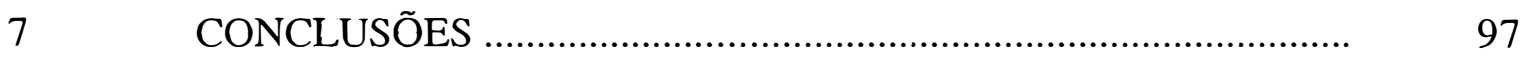

REFERÊNCIAS BIBLIOGRÁFICAS …...................................................... 105 


\section{LISTA DE FIGURAS}

Página

Regiões de produção do estado do Mato Grosso

Gastos de uma propriedade com os principais produtos

produzidos.

Receitas de uma propriedade por produto, em reais junho/2000. 40

4

Saldo (em reais) de uma propriedade em Tangará da Serra

incluindo todas as atividades; julho/2000.

Saldos da propriedade por cultura

Fluxo das despesas por cultura - Carazinho/RS

Fluxos das receitas por cultura - Carazinho/RS.

Fluxo dos saldos por cultura - Carazinho/RS

Segmentação de mercado.

Retorno e desvio absoluto no Mato Grosso - MOTAD.

90

Retorno e desvio absoluto no Rio Grande do Sul - MOTAD....

90

Fronteira eficiente no Rio Grande do Sul - modelo E-V. 
15 Inclinação das tangentes dos pontos dos portfólios de produção. 94

16 Fronteira eficiente - Mato Grosso - Modelo E-V...................... 94

17 Fronteira eficiente - Rio Grande do Sul - Modelo E-V............... 95 


\section{LISTAS DE TABELAS}

Página

1 Fontes de recursos de produtores e cooperativas, em

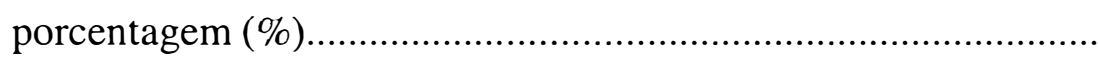

2 Recursos das operações de crédito para a agricultura, por ano, em mil reais

CPR`s avalizadas pelo Banco do Brasil, 1994/98.

Proporção das três principais culturas no Valor Bruto da

Produção.

5 Principais culturas produzidas no Mato Grosso, por ano, em toneladas.

Rendimento médio dos principais produtos agrícolas, por estado, em quilogramas por hectare, e sua respectiva classificação no total do Brasil.

Principais culturas produzidas no Mato Grosso e respectivas classificações no ranking nacional.

Distribuição das culturas e a atividade pecuária nas principais regiões do estado do Mato Grosso 
10 Grupos de área total e sua utilização na Região 1 (Primavera do Leste/MT)

11 Grupos de área total e sua utilização na Região 2

(Rondonópolis/MT).

12 Grupos de área total e sua utilização na Região 3 (Lucas do Rio Verde e Sorriso/MT.

13 Grupos de área total e sua utilização na Região 4 (Parecis/MT)..

14 Propriedade típica em Sorriso/MT, em hectares.

15 Propriedade típica de Tangará da Serra/MT, em hectares

17 Investimentos (Máquinas, implementos, benfeitorias e outros)

de uma propriedade típica do Mato Grosso

18 Produção e participação do Rio Grande do Sul no total produzido em 98/99.

19 Produção por estrato de área (ha), noroeste do RS, 1996.

20 Modelo de propriedade típica em Carazinhos área em hectares..

21 Retorno líquido das atividades no Mato Grosso, safra 99/2000...

22 Fluxo de caixa da propriedade típica do Mato Grosso, safra $99 / 2000$

Resultados do modelo de maximização da renda no Mato

Grosso.

Produtividade média por hectare - Mato Grosso

25 Fluxo comercial da produção de uma propriedade típica do Mato Grosso. 
27 Desvios absolutos da receita bruta - Mato Grosso....................... 68

28 Resultados do MOTAD aplicado no Mato Grosso...................... 70

29 Retorno por atividade............................................................

30 Fluxo de caixa de um hectare numa propriedade em

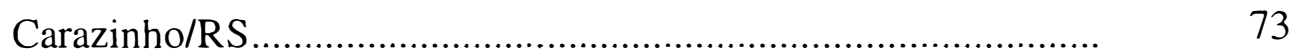

31 Resultados do modelo de maximização.......................................

32 . Fluxo comercial de uma propriedade em Carazinho/RS .............. 75

33 Desvios de receita bruta no Rio Grande do Sul........................... 76

34 Resultados do MOTAD aplicado no Rio Grande do Sul............... 77

35 Modelo quadrático aplicado no Mato Grosso............................... 82

$36 \quad$ Modelo quadrático aplicado no Rio Grande do Sul.................... 87 


\title{
DIVERSIFICAÇÃO COMO FORMA DE GERENCIAMENTO
}

\author{
DE RISCO NA AGRICULTURA
}

Autor: SERGIO DE ZEN

Orientador: Prof. GERALDO SANT'ANA DE CAMARGO BARROS

\section{RESUMO}

Este estudo teve como finalidade mostrar a importância da diversificação no processo de gerenciamento dos riscos da renda. Para tanto, foram escolhidas duas regiões de agricultura intensiva, mas com estruturas fundiárias diferentes. O Mato Grosso representa uma região de grandes propriedades e o Rio Grande do Sul, de pequenas. Nas duas regiões, as principais opções de atividades são culturas anuais e pecuária de corte. Os dados e os modelos adotados nas duas regiões permitiram que fossem feitas comparações dos dois tipos de agricultores perante uma situação de risco. Para contextualizar o cenário em que se encontram os produtores alvos deste trabalho, é feita uma breve análise das transformações da política agrícola brasileira nas últimas décadas. O Estado deixou de ser um agente fornecedor de crédito subsidiado e patemalista. No processo de comercialização, o poder público modificou a sua atuação, reduzindo seu papel de sustentação de preços, deixando mais espaço para a formação de preços nos mercados agropecuários. Também grande parte dos financiamentos passaram 
a ser fornecidos a taxas de mercado, substancialmente maiores que as taxas oficiais. $\mathrm{O}$ trabalho é desenvolvido a partir de três hipóteses: a) os produtores rurais das regiões estudadas diversificam suas atividades utilizando técnicas modernas; b) a diversificação tem sido eficaz na redução dos riscos dos produtores; c) os produtores tendem a se aproximar na fronteira possível de eficiência embora difiram em as taxas de aversão ao risco. Através dos modelos matemáticos, objetiva-se ratificar ou refutar essas hipóteses. Os dados relativos à receita líquida do produtor foram levantados em campo, através de painéis nas regiões de produção, e os dados históricos foram coletados de fontes secundárias como IBGE, Emater do MT e RS, FGV e Cepea/Esalq/USP. Na análise dos dados foram empregados os modelos linear e quadrático. O modelo linear - MOTAD utiliza os desvios absolutos como forma de medida de risco; já o modelo quadrático Modelo E-V- utiliza a matriz de variância e covariância como medida de risco. Os desvios foram estimados subtraindo as séries históricas da receita bruta de cada cultura dos respectivos valores estimados por regressão linear simples. Os resultados dos modelos de minimização de risco permitiram a construção da fronteira eficiente para os dois tipos de propriedades. Na fronteira de eficiência econômica, foi observado o ponto correspondente à propriedade típica da região estudada. A inclinação da fronteira nesse ponto fornece a taxa de aversão ao risco do agricultor. Os resultados permitiram verificar que em todos os níveis de receita esperada a diversificação reduz os riscos dos produtores, sendo que as taxas de aversão aos riscos dos produtores gaúchos são mais elevadas que as do mato-grossense. 


\section{DIVERSIFICATION OF ACTIVITIES \\ FOR AGRICULTURAL RISK MANAGEMENT}

Author: SERGIO DE ZEN

Adviser: Prof. GERALDO SANT'ANA DE CAMARGO BARROS

\section{SUMMARY}

The objective of this study was the importance of diversification to the process of agricultural risk management. For this purpose, two areas with intensive agricultural activities and different agrarian structures were chosen. Mato Grosso is a region with large farms while Rio Grande do Sul with small ones. In both areas, the main agricultural activities are annual crops and livecattle. The data and models adopted allowed comparisons to be made of two types of farmers before a situation of risk. In order to contextualize the scenario where the target producers of this work are situated, a brief analysis of the changes occurred in the Brazilian agricultural policies over the last decades was made. The Public Sector is no longer the paternallistic provider of subsided credit. In the commecialization process, the government has also changed its role, no longer controling prices. Most of the price formation process is left to market forces. The work was developed from three hypotheses: a) farmers of the areas studied diversify their activities, using modem techniques; b) the diversification has efficiently reduced farmers' risks; and c) farmers tend to get close to the economic efficiency frontier, though at different degrees of risk-aversion. The data related to farmers' net revenue 
were collected in the field, by means of panels; the historical data were collected from secondary sources, such as IBGE, Emater from Mato Grosso and Rio Grande do Sul, Conab, FVG and Cepea/Esalq/USP. The linear and quadratic models were used in the analysis. The linear model - MOTAD - uses the absolute deviations as its risk evaluation device. The quadratic model - E-V Model - uses the variance and covariance matrix as its risk evaluation device. The deviations were estimated by comparing time series of gross revenue with its estimated value from simple linear regression analysis. The results of the risk minimization models allowed the construction of an efficiency frontier line for both kinds of properties. Along the economical efficiency frontier, the poin corresponding to the typical farm was identified, thus allowing to estimate the typical farmer's risk aversion rate. The results showed us that diversification reduces farmers' risks at all levels of the revenue and that the risk aversion rate of farmers from Rio Grande do Sul is higher than that of farmers from Mato Grosso. 


\section{INTRODUÇÃO}

Os produtores rurais, em geral, ao administrar suas propriedades enfrentam problemas para obter rentabilidade de suas atividades dentro de limites aceitáveis de risco. Mecanismos tradicionais de gerenciamento de risco, entre os quais aparece a diversificação de atividades, muitas vezes, comprometem a rentabilidade do empreendimento à medida que restringem a plena exploração das vantagens comparativas relacionadas aos recursos disponíveis. Esta situação tem sido apontada como uma das responsáveis pelo atraso em termos de desenvolvimento de regiões agropecuárias, já que inibe o uso de tecnologias, tolhe o crescimento da renda, da poupança e, em conseqüência, do investimento no setor.

Diante deste quadro, o setor público de vários países tem assumido o papel de promotor do desenvolvimento agropecuário, gerando estabilidade e colaborando no gerenciamento do risco dessas atividades. No Brasil, no período compreendido entre a década de 60 e final dos anos 80, houve uma política agrícola ativa implementada com esse objetivo por parte do Estado. As bases dessa política sustentavam-se no crédito farto e subsidiado e na sustentação de preços com a intervenção do Estado no processo de comercialização. Por esse motivo, muitos produtores relegaram a segundo plano a preocupação com práticas administrativas voltadas para o gerenciamento de riscos.

Essas políticas, porém, sofreram restrições crescentes ao longo da década de 90 . O Estado deixou de atuar de forma ativa na política agrícola, tanto no fornecimento de crédito quanto na comercialização. Dessa forma, o produtor passou a se deparar com 
uma realidade distinta, com as normas de mercado ditando o comportamento das taxas de juros e dos preços dos produtos agrícolas.

A atividade rural deixou de ser protegida por políticas do governo e passa a viver em maior grau a realidade dos riscos de mercado, além do tradicional risco de produção. Dessa forma, a renda da propriedade rural ficou ainda mais exposta à variação dos preços e da produtividade.

O produtor passou, então, a buscar alternativas para se adaptar a essa nova realidade. Dentre elas, a diversificação de atividades salta como forma de gerenciar as oscilações da renda da propriedade. O que tem sido observado é um processo de diversificação de uma agropecuária baseada em tecnologia moderna e empresarial, ou seja, o principio do desenvolvimento lógico observado na agropecuária tradicional, agora, ressurge num contexto dinâmico de elevada tecnologia. É esta conjuntura

Nesta pesquisa, as atenções concentram-se justamente nesta conjuntura, que será norteada pelos seguintes pontos a serem investigados: (a) de que forma se processa a diversificação num contexto de agricultura moderna?; (b) essa diversificação é eficaz em termos de redução de riscos?; e (c) os produtores têm implementado esta administração de risco via diversificação de foram eficiente? A abordagem empregada é a aplicação de modelagem matemática com dados obtidos a partir de painéis com grupos de produtores representativos do Mato Grosso e do Rio Grande do Sul.

\subsection{Estrutura da tese}

A tese está dividida em sete capítulos: Introdução, onde é contextualizada a história da política agrícola brasileira, e apresentados os Objetivos e Hipóteses do estudo; Revisão da Literatura relacionada ao trabalho; Fontes dos Dados; as Regiões de 
Estudo; na seqüência, em Metodologia, são desenvolvidos os modelos matemáticos; apresentam-se os Resultados no capítulo seguinte e, por fim, são tecidas as conclusões.

A partir dos estudos da política agrícola brasileira, identifica-se que ocorreu uma série de transformações nos últimos anos, as quais acarretaram significativas modificações nas unidades de produção, que se tornaram mais expostas às leis de livre mercado. Com isto, os desafios dos empresários rurais também se apresentam diferentes, já que os riscos da atividade agrícola cresceram.

Para retratar esse período histórico de transição, o primeiro capítulo faz uma análise do processo de evolução da política agrícola do Brasil ao longo dos últimos 35 anos. A finalidade é traçar uma pequena revisão das políticas adotadas no país - a sua importância e seu desmonte diante dos programas que estão se sucedendo - e ainda das alternativas públicas e privadas, ou seja, dos novos instrumentos disponíveis à administração da propriedade rural.

Posteriormente, são definidos os objetivos e as hipóteses do estudo, buscando esclarecer os principais focos a serem abordados ao longo do trabalho.

$\mathrm{Na}$ segunda fase é apresentado um estudo das propriedades rurais em diferentes regiões do país que possibilita o conhecimento das estruturas de produção e do conjunto de produtos que compõem o portfólio de produção dessas propriedades rurais. A análise dos resultados deste estudo tem por objetivo avaliar a eficiência da diversificação dessas propriedades no sentido de obter uma estabilidade da renda dessas unidades.

No terceiro capítulo, são definidos os dados que serão utilizados nos modelos, as informações primárias e os métodos de coleta. Os dados primários são obtidos através de um instrumental próprio, definido nesta fase. No mesmo capítulo, é aprofundado o estudo das regiões-alvo da pesquisa através de levantamentos de campo combinados com dados secundários do IBGE, (Fundação Instituto Brasileiro de Geografia e Estatística), Emater/MT e RS, Cepea (Centro de Estudos Avançados em Economia 
Aplicada - Esalq/USP), FGV (Fundação Getúlio Vargas) e Conab (Companhia Nacional de Abastecimento).

O resultado dessa etapa é a definição das propriedades típicas das regiões em estudo. Nesta etapa é avaliada a importância do conjunto de atividades utilizado em cada uma das regiões para o gerenciamento dos riscos, e como esses conjuntos de atividades poderiam evoluir no sentido de melhorar a administração dos riscos. Além do conjunto de atividades, será necessário o conhecimento do comportamento dos preços dos produtos envolvidos nos modelos.

Com base no conjunto de informações, são elaborados os modelos, de acordo com a abordagem metodológica pré-definida. Nesta etapa, são criados, então, dois modelos: o linear, cuja medida de risco são os desvios absolutos, e o quadrático, que tem como principal característica a utilização de uma matriz de variância e covariância. Por fim, os dados são analisados de maneira a comparar os modelos e as regiões, considerando-se as deficiências dos modelos e as características de cada uma das regiões.

Na seqüência, são discutidos os resultados do trabalho e suas implicações dentro das atividades agrícolas das duas regiões, e, finalmente, as conclusões do trabalho.

\subsection{Políticas públicas para o setor agrícola}

A intervenção do Estado na formulação de políticas de apoio à agricultura data do início do século, com medidas de incentivo à cultura do café. Estas políticas tinham o objetivo de oferecer proteção à renda dos produtores de café via eliminação de estoque ou através de políticas cambiais favoráveis. O processo de industrialização do país 
trouxe a necessidade de maior oferta de alimentos para a crescente população urbana, mas a política desenvolvimentista ofereceu poucas medidas no sentido de dirigir o processo de modernização da agricultura, que ficou relegado a um segundo plano. A intervenção efetiva e o processo de direcionamento de modernização da agricultura brasileira saíram do papel com a política intervencionista para a agricultura, que marcou o regime pós- 1964 .

Nesse sentido, alguns fatores contribuíram de maneira marcante, dentre os quais podem ser destacados a ocupação do cerrado de maneira contínua, o investimento em pesquisa e a ação efetiva de uma política de crédito e de garantia de preços. Neste trabalho, serão apenas tratados os pontos relativos ao histórico dessa política agrícola e ao seu desmonte.

A produção agrícola do Brasil, no período compreendido entre a década de 60 e o final da década de 80 , foi amparada por políticas públicas de intensa ação sobre o processo produtivo. Essas políticas tinham por finalidade básica fomentar a adoção de inovações tecnológicas, incentivar a diversificação da produção nacional e a expansão das fronteiras agrícolas. Para tanto, era oferecida ao produtor a oportunidade de acesso a modernos insumos de produção que possibilitaram um aumento de produtividade. No entanto, esse aumento de produtividade implicou num aumento de investimento.

A atuação do Estado pode ser dividida em duas frentes de ação: uma voltada ao processo produtivo, com o enfoque para o crédito ao investimento e ao custeio; e a outra, à comercialização, representada por uma política de preços mínimos que teve a finalidade de reduzir as oscilações dos preços e, dessa forma, diminuir os riscos de variações desfavoráveis de rentabilidade.

O crédito de custeio foi um mecanismo que modificou as relações comerciais entre os produtores rurais e seus fornecedores. Os produtores anteriormente utilizavam pequenos volumes de crédito, em condições de mercado, oferecidos por fornecedores; depois passaram a contar com crédito abundante e subsidiado pelo Estado. 
A política de garantia de preços, ou política de preços mínimos, foi um conjunto de medidas que garantia ao produtor, mesmo em momentos de excesso de produção, a manutenção do seu poder de compra, minimizando, em muitas ocasiões, os efeitos do comportamento inesperado dos preços, fugindo das regras de mercado dentro de uma economia capitalista. Isto significa que os preços de equilíbrio determinados pela oferta e demandas não seriam atingidos. Os produtores rurais não teriam que se preocupar com a oscilação dos preços como uma forma de choque que deprime a sua renda.

A implementação dessas políticas se deu tanto pela aquisição do produto por parte do governo como pelo crédito subsidiado oferecido aos produtores para que esses pudessem manter sua produção estocada, ofertando-a somente em momentos em que as condições de mercado fossem mais favoráveis.

As políticas de garantia de preço acabaram moldando o mercado pelo seu pesado grau de intervenção. A produção não se ajustava via preços, mas dependia também da capacidade do governo em adquirir o produto. Nas regiões de fronteira agrícola, onde as condições de transporte e os canais de comercialização não estavam desenvolvidos, a atuação do governo foi preponderante para viabilizar a abertura de novas áreas.

As políticas desenvolvidas pelo governo, principalmente no âmbito do governo federal, independente das qualidades ou dos defeitos que apresentassem, mostraram-se, ao longo do tempo, de elevado custo e de difícil manutenção para os cofres públicos. Os desequilíbrios nas contas públicas, cada vez mais, representavam um fator de preocupação para os governos, dificultando esse tipo de política agrícola. Diante desses fatos, no final da década de 80 , o governo iniciou um processo de redução dos subsídios e do volume de recursos colocado à disposição do setor. Esse processo se acelerou ao longo dos anos 90.

O resultado da então oferta excessiva de crédito público foi uma agricultura desenvolvida em termos tecnológicos, mas dependente em termos financeiros. Desde o início das medidas restritivas de apoio financeiro à agricultura, o produtor passou a necessitar de outros meios de financiamento do custeio, uma vez que não mais pode 
contar com o crédito subsidiado. Os preços também passam a oscilar de acordo com as condições de mercado, pois o governo deixou claro que não dispunha de condições para fazer as aquisições necessárias para manutenção dos preços. Além disso, houve um outro fato agravante para o produtor: trata-se da necessidade de se adequar aos padrões de preços internacionais, dado o processo de abertura e integração econômica do país.

É neste contexto que são estudados os novos instrumentos que os produtores têm para financiar a sua produção e gerenciar os riscos da atividade. As alternativas de financiamento para custeio passam obrigatoriamente por mecanismos de mercado, ou seja, os custos do financiamento estão atrelados às taxas de juros de mercado e aos riscos da atividade. Nessas condições, o dinheiro tanto pode vir de agentes financeiros como de fornecedores de insumos ou dos compradores da produção.

A proteção relativa às oscilações de preços deve ficar por conta da utilização das operações a futuro em bolsa e a termo, tanto no mercado interno como internacional. Os recursos que movimentam esses mercados são de origem privada, sem a participação do setor público. O mercado funciona de maneira que os riscos dos produtores são divididos com pessoas que dispõem de capital e buscam alternativas de investimento.

Os mercados futuros e a termo de produtos agrícolas praticamente começaram a operar significativamente no Brasil no início da década de 90 , mas ainda estão num processo inicial. Pode-se dizer que o mercado futuro é um instrumento ainda pouco comum para os vários agentes que atuam nos segmentos agrícolas. Já os mercados a termo têm aumentado de forma generalizada, seja de maneira formal registradas pelo Banco Central através de CPR's, seja, principalmente, por meio de acordos informais entre produtores e empresas de insumos e agroindústrias. Nos EUA, a utilização do mercado futuro e de opções marcou intensamente a estabilização dos preços e, combinada com outras estratégias dentro da propriedade, têm se mostrado eficientes no gerenciamento dos riscos da atividade agrícola. 


\subsubsection{Esgotamento do sistema de crédito e alternativas públicas de atuação}

A política agrícola nacional passou por um processo de esgotamento no final dos anos 80 , quando o governo brasileiro, movido por crises internacionais e por um colapso das políticas monetária e fiscal, foi forçado a alterar a política de crédito rural.

A prioridade do governo passou a ser o controle da inflação e o Estado é forçado a reconsiderar os seus gastos no sentido de controlá-los e tomar as finanças do país passíveis de serem administradas. 


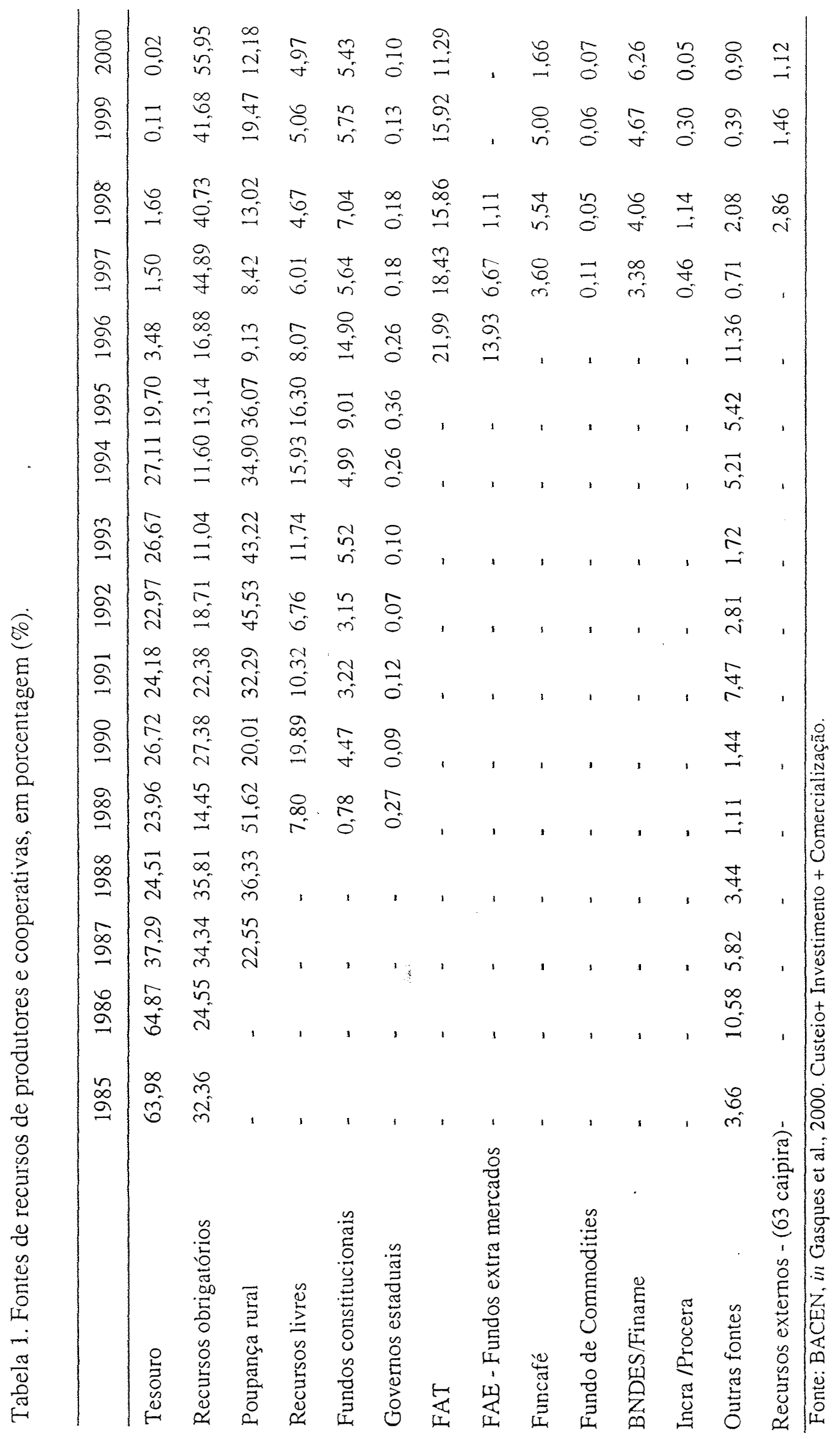


As fontes de recursos alteraram-se substancialmente ao longo da última década, como pode ser visto na Tabela 1 . O Tesouro Nacional perde importância como fonte de recursos para o crédito rural e outras vias ganham destaque. De acordo com Araújo (1999), o FAT (Fundo de Amparo ao Trabalhador) cresce em importância como fonte de recursos, e a captação externa também aumenta. As exigibilidades bancárias também ganham espaço, pois com a estabilização das taxas de inflação, o volume de depósitos à vista cresceu. Essas novas fontes de recursos diferem das formas anteriores pela inclusão de um pesado "spread" sob o título de taxa de risco.

Neste quadro, fica claro que a atuação do governo na política de crédito rural perde força, resultando em um volume total de financiamento reduzido para aproximadamente uma terça parte do montante oferecido há 10 anos.

O volume de crédito advindo do Tesouro tem reduzido, mas também a forma de aplicação desse dinheiro tem sido modificada. O governo deixa de oferecer o crédito integral e passa a fazer uma operação de equacionamento dos recursos, cobrindo a diferença entre o valor da taxa de juros de mercado e a taxa de juros do crédito oficial. Na Tabela 2, é possível verificar que, do montante de recursos aplicado em custeio, a equalização passa a responder por aproximadamente $100 \%$. Nos créditos direcionados à comercialização, a equalização também aumenta a participação.

Tabela 2. Recursos das operações de crédito para a agricultura, por ano, em mil reais.

\begin{tabular}{llll}
\hline & 1997 & 1998 & 1999 \\
\hline Custeio Agropecuário & 230.243 & 288.015 & 158.484 \\
Empréstimo & 694 & - & - \\
Equalização & 229.550 & 288.015 & 158.484 \\
Comercialização & 2.287 .914 & 1.006 .244 & 757.107 \\
EGF & 415.286 & 223.964 & 9.797 \\
Empréstimo & 175.089 & 267.389 & - \\
Equalização & 240.197 & 23.367 & 9.797
\end{tabular}


Tabela 2. Recursos das operações de crédito para a agricultura, por ano, em mil reais

\begin{tabular}{llll}
\hline & 1997 & 1998 & 1999 \\
\hline AGF & 1.872 .628 & 715.488 & 747.310 \\
Empréstimo & 947.250 & 494.858 & 520.305 \\
Equalização & 925.378 & 220.630 & 227.005 \\
Total & 2.518 .159 & 1.294 .259 & 915.591 \\
Empréstimo & 1.123 .033 & 762.247 & 520.305 \\
Equalização & 1.395 .125 & 532.012 & 395.286 \\
\hline
\end{tabular}

Fonte: Ministério da Fazenda - Secretaria do Tesouro, in Gasques 2000.

Essa nova modalidade segue a linha de redução da atuação do governo como agente dentro do mercado, reforçando seu papel de maneira a complementar e moderar as leis de mercado.

O agricultor, nessa nova realidade, está exposto aos riscos do mercado, tanto na oferta como nos custos do dinheiro. As quebras de safra e/ou as oscilações desfavoráveis de preços têm de ser bancadas totalmente por os recursos próprios. Uma queda de produtividade e/ou uma oscilação desfavorável dos preços representam fontes de riscos para a renda do produtor.

\subsubsection{Alternativas estatais de crédito e de gerenciamento de riscos de preços}

Os instrumentos do governo têm sido substituídos por alternativas privadas no gerenciamento dos riscos de preços, como, por exemplo, os mercados futuros de commodities e a venda a termo pelos produtores diretamente para as empresas de insumo e processamento.

A ação do governo também foi alterada de forma significativa buscando a minimização dos gastos e mais eficiência na aplicação dos recursos. Dentre as novas 
modalidades, merecem destaque a CPR (Cédula do Produto Rural), como forma de antecipar os recursos, e o PEP (Prêmio de Escoamento de Produto), como instrumento para manter os preços mínimos, e as Opções, como forma de implementar a comercialização.

As CPR's representam instrumento importante e de grande potencial tanto para assegurar preços antecipados como também para adiantamento de recursos para custeio e comercialização ao produtor. Seu regime de operação baseado no clearing, através da Central de Custódia e Liquidação Financeira de Títulos - CETIP, e no aval de instituição financeira que empresta à CPR os atributos necessários para sua ampla utilização no Brasil. Entretanto, devido a questões relativas a custo de aval, elevadas taxas de juro e falta de padronização dos produtos agropecuários, sua utilização até o momento ainda é bastante reduzida, conforme indicam os dados da Tabela 3.

Tabela 3. CPR`s avalizadas pelo Banco do Brasil, 1994/98.

\begin{tabular}{ll}
\hline Safra & Valor (R \$ milhões) \\
\hline $1994 / 95$ & 31,9 \\
$1995 / 96$ & 65,5 \\
$1996 / 97$ & 66,2 \\
$1997 / 98$ & 20,4 \\
\hline
\end{tabular}

Fonte: Banco do Brasil.

Deve ser destacada também a implementação, pelo governo, na safra de 1997, de um programa de Contratos de Opções de Venda para garantia de preços de milho. Este programa, segundo Barros (1998), apesar do nome semelhante e de basear-se no programa homônimo dos Estados Unidos, guarda grandes diferenças em relação a este último: (a) em primeiro lugar, não se trata de um programa piloto, como foi o americano, posto que está disponível em grandes extensões do território nacional; (b) trata-se de programa de opções envolvendo apenas o mercado físico, ao passo que o programa americano envolvia opções sobre contratos futuros; (c ) as vendas das opções 
são iniciativas do governo e não necessariamente do mercado, como se dá nos EUA (Barros, 1998).

Na safra 98/99, o programa de opções, iniciado na safra 1996/97, ganhou destaque como instrumento de manutenção dos preços do algodão, sendo que este produto foi muito afetado pela desvalorização cambial, uma vez que cerca de $50 \%$ dos seus custos estavam atrelados ao dólar.

O programa de opções, em sua concepção, atende à diretriz de afastar o governo das operações de manuseio das mercadorias e transfere ao produtor a iniciativa de operar no mercado. Cria um tipo de mercado que poderá se desenvolver à medida que o produtor se familiariza com o novo instrumento, podendo evoluir para o ponto em que o setor privado entre diretamente como emissor de opções.

O governo poderá colocar as facilidades de leilões eletrônicos à disposição de empresas que queiram lançar suas próprias opções. O grande receio fica por conta da falta de agilidade do governo para tomar providências necessárias em tempo oportuno, definindo, por exemplo, as regiões e os volumes a serem oferecidos em leilões sucessivos. Fica ainda a dúvida quanto à disponibilidade de recursos em tempo hábil como tem acontecido nos programas tradicionais - para comprar a produção dos produtores que queiram exercer suas opções.

Na safra de 1997/98, foram transacionados contratos de opção de milho correspondentes a mais de um milhão de toneladas, o que demonstra a aceitação bastante satisfatória do instrumento já em lançamento.

O Prêmio de Escoamento de Produto - PEP tem se mostrado o instrumento que oferece maior agilidade e de menor custo para o governo. Por envolver leilões públicos em que os interessados adquirem o produto diretamente do produtor/cooperativa mediante pagamento de um prêmio dado pela diferença entre o preço de referência ou preço mínimo e o preço de mercado, o PEP possibilita grande economia de recursos por parte do governo. Em 1997, foram negociadas mais de um milhão de toneladas de trigo e 
também mais de um milhão de toneladas de milho. Somente em termos de recursos financeiros, foram economizados cerca de $60 \%$ do que seria despendido em operações do tipo AGF com milho.

O PEP foi largamente utilizado na safra 97/98 como forma de garantir o preço mínimo para o produtor de algodão. Esta subvenção foi ofertada pelo governo aos produtores como forma de compensar os baixos preços do algodão em pluma no mercado nacional. Isso levou a um incremento da demanda pelo prêmio, sendo o valor máximo fixado pelo governo. O valor de negociação determinado conforme as leis de mercado. Portanto, em alguns períodos, o prêmio entrava em patamares de $\mathrm{R} \$ 1,50 / @ \mathrm{a}$ $\mathrm{R} \$ 2,00 / @$ e em outros chegava a R\$2,96/@.

Os estados contemplados com o PEP na safra 97/98 foram os seguintes: Paraná, São Paulo, Goiás, Mato Grosso do Sul, Minas Gerais, Bahia e Mato Grosso. A maior oferta de algodão foi do estado do Mato Grosso, com 92.500 toneladas, seguido pelo Paraná (71.000 t.) e depois Goiás (52.500 t.). Foi verificada neste período uma melhor qualidade do algodão mato-grossense, o que veio a ocasionar uma maior procura pelo produto daquele estado. O Mato Grosso acabou vendendo 77,13\% de sua oferta, seguido pelo Paraná com 49,55\% e depois por Minas Gerais com 40,68\%. O estado de Goiás ficou em quinto lugar em porcentagem vendida, de acordo com a oferta no leilão de PEP, devido aos problemas de qualidade da fibra ocasionados pelas pragas e condições climáticas nesse estado.

O gasto do governo com o PEP de algodão na safra 97/98 foi de R $\$ 30.276 .486$. Isto significa que o governo utilizou esse volume de dinheiro para manter os preços no nível estipulado pelo preço mínimo, mas evitou manter o produto em estoque.

A atuação do governo e das empresas privadas no momento de formular planos de ação para atuar junto aos produtores rurais dependem da taxa de aversão ao risco que os produtores possuem. Essa taxa mostra o comportamento que os agricultores têm frente aos riscos. 


\subsection{Objetivos}

O objetivo deste trabalho é estudar o comportamento dos produtores frente aos riscos, tendo como principal enfoque o gerenciamento dos riscos de renda por parte dos produtores através da diversificação das atividades. A análise será feita nos estados do Mato Grosso e do Rio Grande do Sul, utilizando dados de microrregiões do Censo Agrícola de 1996 e de painéis realizados nas regiões, que permitem a concepção de modelos de propriedades típicas.

Com base nos resultados, será possível estudar o portfólio de produção para os estados do Mato Grosso e do Rio Grande do Sul, estimando as taxas de aversão a riscos dos produtores desses estados.

Em síntese, este trabalho busca responder as seguintes questões: (a) como a diversificação está sendo utilizada pelos produtores das duas regiões de estudo?; (b) qual a eficácia dessa estratégia na redução dos riscos de oscilações da renda dos produtores?; (c) o produtor está sendo eficiente no processo de diversificação da renda?

\section{$1.4 \quad$ Hipóteses}

1) Os produtores rurais das regiões estudadas diversificam suas atividades utilizando técnicas modernas.

2) A diversificação tem sido eficaz na redução dos riscos dos produtores.

3) Os produtores tendem a se aproximar da fronteira possível de eficiência embora difiram em taxas de aversão ao risco. 


\section{REVISÃO DE LITERATURA}

O desenvolvimento de técnicas de gerenciamento dos riscos torna-se mais necessário à medida que ocorre um distanciamento do Estado da política agrícola, pois os produtores passam a se defrontar com as realidades do mercado. Neste sentido, o trabalho inicia com a revisão de alguns trabalhos recentes sobre a política agrícola nacional. Na seqüência, analisa os trabalhos da literatura nacional e internacional sobre a diversificação de atividades como forma de redução dos riscos, e, por fim, analisa os modelos disponíveis para o estudo.

Gasques et al. (2000) fazem uma avaliação da evolução das fontes de financiamento da agricultura brasileira e dos modelos adotados em outros países. $\mathrm{O}$ trabalho sugere que o modelo atual está firmado no compromisso do governo em retirarse do quadro de grande financiador da agricultura nacional. O produtor, por sua vez, deve buscar novos instrumentos de crédito privado. O Estado, porém, ainda aparece como grande financiador para o investimento, através do BNDES. Isto, de certa forma, abre espaço para os investimentos necessários para a aquisição de novos implemento para a diversificação de atividades.

Barros (1998) mostra que o agricultor tem nas mãos novos instrumentos tanto privados quanto estatais que modificam as relações comerciais e reduzem a dependência dos agricultores atuais em relação a instrumentos do passado.

Estes trabalhos situam a atual política agrícola nacional face à ação política econômica vigente. O Estado brasileiro propõe-se a uma política monetária e fiscal austeras, com metas inflacionárias que pressupõem equilíbrio das contas públicas. 
Harwood et al. (1999) procuram definir e estudar as maneiras que o agricultor tem para tratar os riscos dentro do processo de produção agrícola. As modificações da política agrícola norte-americana a partir da Farm Act de 1996 tornaram necessárias medidas mais efetivas de proteção da renda dos produtores. Dentre as medidas disponíveis, está a diversificação das atividades nas propriedades.

No mesmo sentido de análise, Carter (1999), em um estudo descritivo, trabalha com pequenas unidades produtoras na Inglaterra que necessitam passar por um processo de diversificação de atividades dentro e fora da propriedade para a manutenção da renda.

O trabalho de Barrett et al. (1993) faz uma relação entre o tamanho da propriedade, a produtividade e o risco de renda dos produtores. Neste caso, é estimado um modelo onde a variância dos retornos está condicionada à produtividade e ao tamanho da propriedade.

Black et al. (2000) tentam estimar um modelo de regressão simples onde a variabilidade da renda, medida pelo coeficiente de variação, é explicada por fatores característicos da propriedade como tamanho, tipo de terra, propriedade da terra, clima e grau de diversificação, bem como por fatores relacionados ao agricultor, como grau de instrução e idade. Neste modelo, o grau de diversificação tem relevância desde que a região possua aptidão para diferentes atividades agrícolas.

Coble \& Barry (1999) tratam o uso da diversificação como mais uma forma de gerenciamento do risco de renda dos produtores rurais dentro de um conjunto de linhas de estudos sobre a administração da propriedade. Neste caso, a diversificação é condicionada ao desenvolvimento genético de um maior número de variedades que ofereçam mais opções ao produtor. Neste trabalho, a opção adotada depende do processo de formação do preço do produto, pois este pode oferecer maior ou menor exposição ao risco. O trabalho indica o uso de contratos de comercialização para eliminar os riscos de flutuação de preços. 
Coble et al. (1996), estudando o modelo de seguro agrícola vigente nos EUA com dados de painel, utilizam o grau de diversificação das atividades agrícolas como uma das variáveis explicativas para a demanda de seguro. Este enfoque mostra que, dentro dos modelos alternativos de política pública americana, a diversificação das atividades é um fator relevante. O fato de uma grande parcela das propriedades estar situada em regiões onde a diversificação de atividades é pouco viável é um fator relevante para o modelo a ser adotado.

A análise das atividades de uma unidade agrícola, utilizando o MOTAD, é encontrada em trabalhos que avaliam os riscos de uma propriedade agrícola. Walbeurger \& Klein (2000) utilizam o modelo para analisar os impactos climáticos mundiais sobre a produção de grãos e oleaginosas na região de Alberta, Austrália. O modelo analisa as relações entre as atividades que podem minimizar a variabilidade da renda do produtor, sendo presentes as opções de produzir trigo, milho, canola, forragem e cevada.

Rudel \& McCamley (2000) propõem modificações no MOTAD original relativas aos desvios considerados. Os autores trabalham apenas com os desvios negativos absolutos. A vantagem, nesse caso, é que apenas os desvios indesejáveis são considerados, mas, ao mesmo tempo, as combinações entre atividade de comportamento diferente não são consideradas.

Nydene et al. (1999) analisam várias estratégias alternativas para o gerenciamento do risco de renda de uma propriedade agrícola. O modelo utilizado para medir o risco é o da média-variância $(\mathrm{E}-\mathrm{V})$. Esses autores propõem várias alternativas de gerenciamento de riscos, incluindo mercado futuro, opções e diversificação, de forma separada e combinada. Os resultados dos custos da utilização de cada um desses métodos com o seguro tradicional mostram que, no contexto da agricultura americana, a combinação de estratégias de opções com mercado futuro é a melhor para gerenciamento do risco. A diversificação das atividades tem como fator limitante a falta de culturas viáveis. 
No trabalho citado, os autores desenvolvem um modelo de simulação de vários cenários para uma propriedade de 1.000 acres. O processo envolveu mais de 800 interações e os resultados são analisados usando o critério de média-variância. No contexto brasileiro, alguns pontos são importantes de serem ressaltados: inexistência de mercado futuro e de op̧̧ões desenvolvidos para os principais produtos comuns às propriedades nacionais; os agricultores dispõem de poucas alternativas de contratos de comercialização, mas, por outro lado, o clima de algumas regiões do país possibilita uma enorme quantidade de produtos para a diversificação de culturas.

Azevedo Filho \& Peres (1982) descrevem um modelo para a análise da estrutura de produção de uma propriedade rural dentro de um ambiente de risco. Este trabalho é uma aproximação do modelo inicialmente proposto por Markowitz (1952), e modificado por Hazell (1971), no qual é utilizado o modelo de média-variância como forma de medida de risco. Com base nos resultados desses modelos, os tomadores de decisão têm instrumentos para avaliar níveis ótimos de produção, tanto em termos de rentabilidade como de variabilidade da rentabilidade.

Silva \& Stulp (2000) discutem a otimização de sistemas agrícolas sob condições de risco. O estudo procura um modelo matemático que permita a distinção entre a tendência das séries e as variações aleatórias. Nesse sentido, são comparadas as seguintes metodologias: minimização das variâncias (MV), minimização dos desvios absolutos (MDVA) e otimização dos desvios interanuais (ODI). O modelo ODI apresenta uma tendência de privilegiar as atividades com tendências positivas, enquanto os demais não são capazes de distinguir as séries com tendências positivas. A explicação complementar para as tendências das séries é considerada de suma importância para a obtenção dos resultados integrais do modelo. Nestes modelos, fica evidente a necessidade de se incorporarem as tendências de longo prazo que a renda agrícola possui.

Dias (1996) trata da inclusão do risco dentro do modelo de planejamento de uma propriedade rural. Os modelos consideram diversas formas de distribuição dos dados, 
sendo que o prévio conhecimento destas é de suma importância para a obtenção de resultados mais consistentes. Assumir a distribuição normal dos dados não é indicado, pois isso pode implicar em distorções dos resultados.

Peres (1976) estudou a demanda por crédito incorporando o risco no modelo E$\mathrm{V}$, em um ambiente de inflação. O trabalho foi conduzido na região de Ribeirão Preto/SP, onde havia um processo de modificação das estruturas de produção, com produtores modernos convivendo com outros atrasados. Neste estudo, o autor utiliza os modelos quadráticos como uma forma de avaliar as características dos produtores em relação ao crédito rural ofertado. Deste trabalho, o ponto relevante ao desenvolvimento do presente estudo diz respeito à metodologia utilizada, que de certa forma, segue as mesmas premissas e incorpora as facilidades de processamento dos dados devido à evolução dos programas e computadores.

Dentre os trabalhos disponíveis, existe uma clara tendência a considerar que a redução dos riscos da atividade agrícola passa por um processo de diversificação das atividades dentro das propriedades. No entanto, faltam estudos neste sentido no Brasil, sendo esta lacuna parcialmente justificável pela falta de dados e pela complexidade da agricultura nacional. A regionalização do estudo é uma necessidade, pois a gama de diversidade de sistemas de produção seguindo as também variadas condições climáticas, culturais e da estrutura fundiária são marcantes. 


\section{FONTES DE DADOS}

Este trabalho utiliza dados de duas origens. A primeira delas são instituições como IBGE (Fundação Instituto Brasileiro de Geografia e Estatística), Emater/MT e RS, Cepea (Centro de Estudos Avançados em Economia Aplicada - Esalq/USP), FGV (Fundação Getúlio Vargas) e Conab que fornecem dados secundários. Os demais dados são apurados de fonte primária, cujos levantamentos foram feitos através de painéis com agricultores, seguindo os moldes descritos por Deblitz (1998).

O conjunto de informações secundárias que permite a caracterização inicial das propriedades-foco deste estudo são oriundas do senso agrícola do IBGE de 1996.A evolução de produtividade tem como origem os dados da Pesquisa Agrícola Municipal do IBGE. Estes dados fornecem embasamento para a caracterização da região escolhida para o trabalho.

Os dados de preços têm como fontes as séries registradas pelo Cepea/Esalq/USP e pela Emater/MT. Esses dados são estruturados de maneira a compor séries de preços médios mensais regionais dos últimos 10 anos. Os dados regionais obtidos referem-se aos últimos cinco anos. O período restante é obtido com base nos diferenciais médios desses preços em relação aos do estado de São Paulo. Dessa forma, os preços do período compreendido entre 1990 e 1995 são uma "proxy" dos preços regionais. Os preços médios mensais são transformados em dados médios anuais ponderando-se pelo volume de comercialização no período de negociação da safra. 
Os dados regionais, no nível de propriedade, foram levantados em painéis com técnicos e fornecem as informações para a construção de uma propriedade típica da região. Os dados são referentes aos tipos de culturas existentes, aos implementos e ao fluxo comercial da propriedade.

No estado do Mato Grosso, essas informações foram levantadas no período de julho e agosto de 2000, em três painéis nas regiões de Sorriso, Rondonópolis e Tangará da Serra. Os grupos eram formados por técnicos regionais, ou seja, possuidores de amplo conhecimento das propriedades da região. Estas características dos painéis realizados são uma adaptação do conceito inicial de painel.

Os dados primários do Rio Grande do Sul foram coletados na região de Carazinho também através de painel. Os dados secundários têm as fontes oficiais do Emater/RS e IBGE. Também foram utilizados dados de produtividade elaborados pelos produtores da região.

\subsection{Painel agrícola}

O painel agrícola é uma forma de coleta de dados descrita em Deblitz (1998). De acordo com esse trabalho, o grupo de pessoas que compõem o painel é o seguinte: um ou mais pesquisadores, um técnico da região e um grupo de 5 a 7 agricultores, no caso de estudos de propriedades; ou um grupo de igual tamanho de agentes setoriais, quando o estudo é dirigido à determinada cadeia agroindustrial.

Os pesquisadores têm a função de definir os temas centrais a serem tratados e, para tanto, devem ter um prévio conhecimento dos objetivos do estudo. Numa primeira etapa do processo, esses profissionais devem fazer, com base em dados secundários, um estudo antecipado da região ou setor. 
Uma segunda etapa do processo consiste na escolha de um técnico regional que deve fornecer as informações sobre as especificidades regionais e indicar os produtores que representarão a unidade típica.

A terceira etapa consiste na realização do painel propriamente dito, reunindo os pesquisadores, o técnico e o grupo de produtores. Nesta etapa, os dados secundários e as informações fornecidas pelo técnico são debatidos e questionados, buscando-se o consenso do grupo.

$\mathrm{Na}$ quarta etapa da pesquisa são feitas a tabulação e a análise detalhada dos resultados obtidos, que deverão ser levados ao conhecimento dos produtores que participaram do painel, visando a manter uma estreita relação entre estes e o Centro de Pesquisa.

No caso específico dos painéis desenvolvidos para esse trabalho, o grupo foi um pouco distinto, sendo constituído por agentes técnicos de uma empresa com atuação no fornecimento dos seguintes serviços e produtos: assessoria técnica, venda de insumos e aquisição dos produtos. As informações coletadas nesse grupo proporcionaram a definição de uma propriedade típica para a região central do Mato Grosso. O mesmo procedimento foi feito em Carazinho/RS. 


\section{REGIÕES DE ESTUDO}

O Brasil é o país com a maior área agricultável do planeta e isto credencia como um dos maiores fornecedores de alimentos para a humanidade, com grande capacidade de crescimento dessa oferta, seja ela pela expansão de área, ou pelos ganhos de produtividade. O país tem condições climáticas para produzir culturas comerciais em praticamente todas as unidades da Federação. No entanto, algumas regiões apresentam melhores condições de competitividade por características edafoclimáticas e/ou fundiárias, para determinadas culturas. Desta forma, os estados possuem capacidades distintas de diversificação das atividades produtivas devido a características regionais. A decisão de diversificar as atividades dentro de uma propriedade deve levar em conta a capacidade de produção de outras regiões que podem produzir com vantagens comparativas.

As propriedades rurais brasileiras, principalmente nas áreas de ocupação recente, estão mais voltadas para um sistema de produção empresarial baseado em regras de mercado. O Estado, como foi descrito, deixou de intervir no sentido de alterar o comportamento do mercado e as flutuações de preços e de produtividade afetam de maneira direta a renda da empresa agrícola. A solução para enfrentar essas incertezas é buscar alternativas dentro do sistema produtivo, mas sem comprometer em demasia o nível de rendimento. Uma opção é a diversificação das atividades dentro da propriedade. A Tabela 4, a seguir, apresenta os dados dos principais estados produtores agrícolas brasileiros. É possível verificar que os estados da região Centro-Oeste do país têm uma menor diversificação de suas atividades. No Mato Grosso do Sul e no Mato Grosso, as 
três principais atividades agrícolas respondem por mais de $70 \%$ do valor bruto da produção. As culturas que concentram esses valores no Mato Grosso são soja, commais de $60 \%$ do total, arroz e algodão. Isso é mais um indicativo de que a atividade agrícola nesse estado é concentrada em alguns poucos produtos.

Tabela 4. Proporção das três principais culturas no Valor Bruto da Produção.

\begin{tabular}{ll}
\hline Estado & Concentração \\
\hline São Paulo & $56,06 \%$ \\
Rio Grande do Sul & $58,52 \%$ \\
Paraná & $58,67 \%$ \\
Minas Gerais & $60,50 \%$ \\
Mato Grosso do Sul & $79,53 \%$ \\
Mato Grosso & $78,36 \%$ \\
Goiás & $66,44 \%$ \\
\hline
\end{tabular}

Fonte: IBGE - Produção Agrícola Municipal, 1996.

As diversificações das atividades no nível regional estão condicionadas a fatores locais, aos perfis dos agricultores e às opções de atividades disponíveis na área. No entanto, o produtor não pode tomar a sua decisão desconsiderando as relações que existem entre a produção local e as demais regiões produtoras. As dimensões continentais do Brasil possibilitam que a disponibilidade de um produto se mantenha estável mesmo com a frustração de safra de uma região, pois esse fato pode ser compensado pela ocorrência de produtividade excepcional em outra região. Portanto, o conhecimento das principais regiões concorrentes dos produtos básicos é relevante para a concepção de modelos de diversificação.

Nesta etapa do trabalho será feita, com base em dados do IBGE e Conab, bem como em levantamentos de dados primários, uma descrição de algumas das principais regiốes produtoras do país com a finalidade de situar o Mato Grosso em relação às 
demais regiões do país, a partir das culturas comerciais relevantes para o estado. $\mathrm{Na}$ sequiência, o mesmo é feito para o Rio Grande do Sul.

\subsection{Mato Grosso}

O estado do Mato Grosso ganha destaque na produção agrícola nacional a partir do início da década de 90. Este estado, de acordo com os dados do IBGE, em 1980 tinha apenas relevância na produção de arroz. No entanto, é importante ressaltar que essa cultura é utilizada com a finalidade de auxiliar na abertura do cerrado. $\mathrm{O}$ arroz produzido é de sequeiro, com variedades pouco aceitas no mercado nacional, o que significa que boa parte desse produto pode ter como destino os estoques do governo federal.

As demais culturas tinham pequeno destaque, sendo que no início da década de 80 a soja em escala comercial estava em fase inicial de implantação e o milho era uma cultura já presente no estado, mas apenas para atender à demanda local. O algodão somente viria a ganhar espaço na segunda metade da década de 90.

A pecuária extensiva também era uma atividade que já estava presente em larga escala no estado, sendo usada em conjunto com o arroz para a abertura do cerrado.

Tabela 5. Principais culturas produzidas no Mato Grosso, por ano, em toneladas.

\begin{tabular}{lllll}
\hline Ano & Algodão & Arroz & Milho & Soja \\
\hline 1980 & 4.914 & 1.175 .041 & 142.572 & 117.173 \\
1985 & 21.837 & 521.776 & 410.500 & 1.656 .039 \\
1990 & 57.634 & 420.722 & 618.973 & 3.064 .715 \\
1991 & 73.458 & 465.826 & 669.683 & 2.738 .410 \\
1992 & 67.862 & 850.743 & 763.907 & 3.642 .743
\end{tabular}


Tabela 5. Principais culturas produzidas no Mato Grosso, por ano, em toneladas.

\begin{tabular}{lllll}
\hline Ano & Algodão & Arroz & Milho & Soja \\
\hline 1993 & 85.641 & 587.590 & 908.186 & 4.118 .726 \\
1994 & 91.828 & 812.439 & 1.163 .551 & 5.319 .793 \\
1995 & 87.458 & 762.327 & 1.226 .157 & 5.491 .426 \\
1996 & 73.553 & 722.293 & 1.513 .630 & 5.032 .921 \\
1997 & 78.376 & 694.904 & 1.520 .695 & 6.063 .402 \\
1998 & 270.415 & 774.735 & 1.000 .908 & 7.159 .751 \\
\hline
\end{tabular}

Fonte: IBGE.

Nos anos 90, para efeito de caracterização agrícola, o estado pode ser dividido em quatro regiões produtivas: "Baixada Cuiabana", "Araguaia - Xingu", "Extremo Norte" e "Chapadão Central". Destas, as duas primeiras são caracterizadas pela produção extensiva de pecuária de corte. O Extremo Norte ou "Nortão" , como popularmente é denominada, é a região onde predomina a floresta Amazônica. A área típica de agricultura e de atividade pecuária é o "Chapadão Central", portanto, o principal foco deste estudo.

A região tem como característica principal um elevado grau de tecnologia, tanto nas técnicas produtivas (plantio direto), quanto na administração (acompanhamento de custo, fluxo de caixa etc). Os números da Conab atestam essa característica com o crescimento acentuado da produtividade dos principais produtos da região: arroz 19\%, soja 7\% e algodão 9,5\% (médias das safras 98/99 e 99/00). Além disso, as produtividades do algodão e da soja se destacam das dos demais estados. A Tabela 6 mostra o rendimento médio da produção para os principais produtos em vários estados brasileiros. 
Tabela 6. Rendimento médio dos principais produtos agrícolas, por estado, em quilogramas por hectare, e sua respectiva classificação no total do Brasil.

\begin{tabular}{lllllllll}
\hline Estado & Algodão & Clas. & Arroz & Clas. & Milho & Clas. & Soja & Clas. \\
MT & 2.545 & 1 & 2.132 & 5 & 2.308 & 7 & 2.734 & 1 \\
GO & 1.395 & 6 & 1.637 & 7 & 3.810 & 1 & 2.465 & 3 \\
MS & 1.896 & 2 & 3.410 & 2 & 3.508 & 3 & 2.091 & 5 \\
MG & 1.481 & 5 & 1.840 & 6 & 2.936 & 5 & 2.268 & 4 \\
PR & 1.507 & 4 & 2.138 & 4 & 3.558 & 2 & 2.558 & 2 \\
RS & - & - & 4.317 & 1 & 2.960 & 6 & 2.037 & 6 \\
SP & 1.570 & 3 & 2.183 & 3 & 3.323 & 4 & 1.949 & 7 \\
Brasil & 1.420 & - & 2.519 & - & 2.796 & - & 2.353 & - \\
\hline
\end{tabular}

Fonte: IBGE, 1996.

Essa elevada produtividade e o crescimento contínuo da área plantada podem ser atribuídos a algumas características estruturais básicas das propriedades, dos investimentos em pesquisa e do clima. As características das propriedades permitem traçar um perfil dessas unidades, obtendo informações sobre quando e como os produtores compram e vendem, além da forma como financiam o processo produtivo.

Os incentivos governamentais têm se mostrado grandes em culturas como o algodão, arroz e milho, mas tal intervenção é praticamente nula para a soja. No caso da atividade pecuária, o incentivo do governo via BNDES se dá pelo financiamento de novos frigoríficos ou reestruturação dos antigos . No caso do algodão, os volumes de crédito de custeio são pequenos, sendo que as maiores intervenções ocorrem na comercialização do produto, através de dois programas do governo federal: o Prêmio de Escoamento de Produto - PEP e o Programa de Opções do Governo Federal. Além desses programas federais, os produtores contam com a renúncia fiscal por parte do governo estadual, que devolve aos produtores $75 \%$ do ICMS recolhido sobre o algodão.

A comercialização no Mato Grosso não é feita através de cooperativas. A produção da soja, por exemplo, é comercializada diretamente com as grandes indústrias de grãos, que atuam de diversas maneiras: desde o adiantamento para o custeio de 
insumos até a compra pura. No entanto, é importante ressaltar que este produto é balizado pela intemalização das cotações da Bolsa de Chicago, o que permite que o produtor possa fazer a venda antecipada.

A pecuária de corte segue os mesmos padrões comerciais de outras regiões do país, ou seja, tem um difícil relacionamento entre produtores e indústria no que tange ao recolhimento de impostos, ao rendimento de carcaça e aos riscos de recebimento. Nas propriedades, a importância da pecuária está na capacidade de representar uma expressiva reserva de valor. Destaca-se que a comercialização dos animais ocorre praticamente durante todo o ano.

\subsubsection{Mato Grosso no cenário nacional}

Este estado é o maior produtor nacional de soja e algodão, tendo também as maiores taxas de produtividade. No caso de ambos produtos, a eficiência do sistema de produção faz com que os custos de frete não inviabilizem essas atividades. Já para o arroz e o milho, o sistema produtivo não é capaz de cobrir os custos de transporte. $\mathrm{O}$ milho tem a produção voltada para o mercado interno, cobrindo inclusive casos extremos de preços do produto, quando ocorre falta em outras regiões. 
Tabela 7. Principais culturas produzidas no Mato Grosso e respectivas classificações no ranking nacional.

\begin{tabular}{lll}
\hline Produtos & Produção (mil t) & Ranking no Brasil \\
\hline Soja & $4.072,6$ & 1 \\
Algodão & 335,8 & 1 \\
Boi - Abate ( t ) & $457.876,0$ & 4 \\
Arroz & 1890,8 & 2 \\
Milho safra & 726,9 & 8 \\
Milho safrinha & 769,0 & 5 \\
\hline
\end{tabular}

Fonte: Conab, safra 1999/2000; IBGE, 1996.

\subsubsection{Descrição regional}

O estado pode ser dividido em quatro regiões de produção, conforme Figura 1:

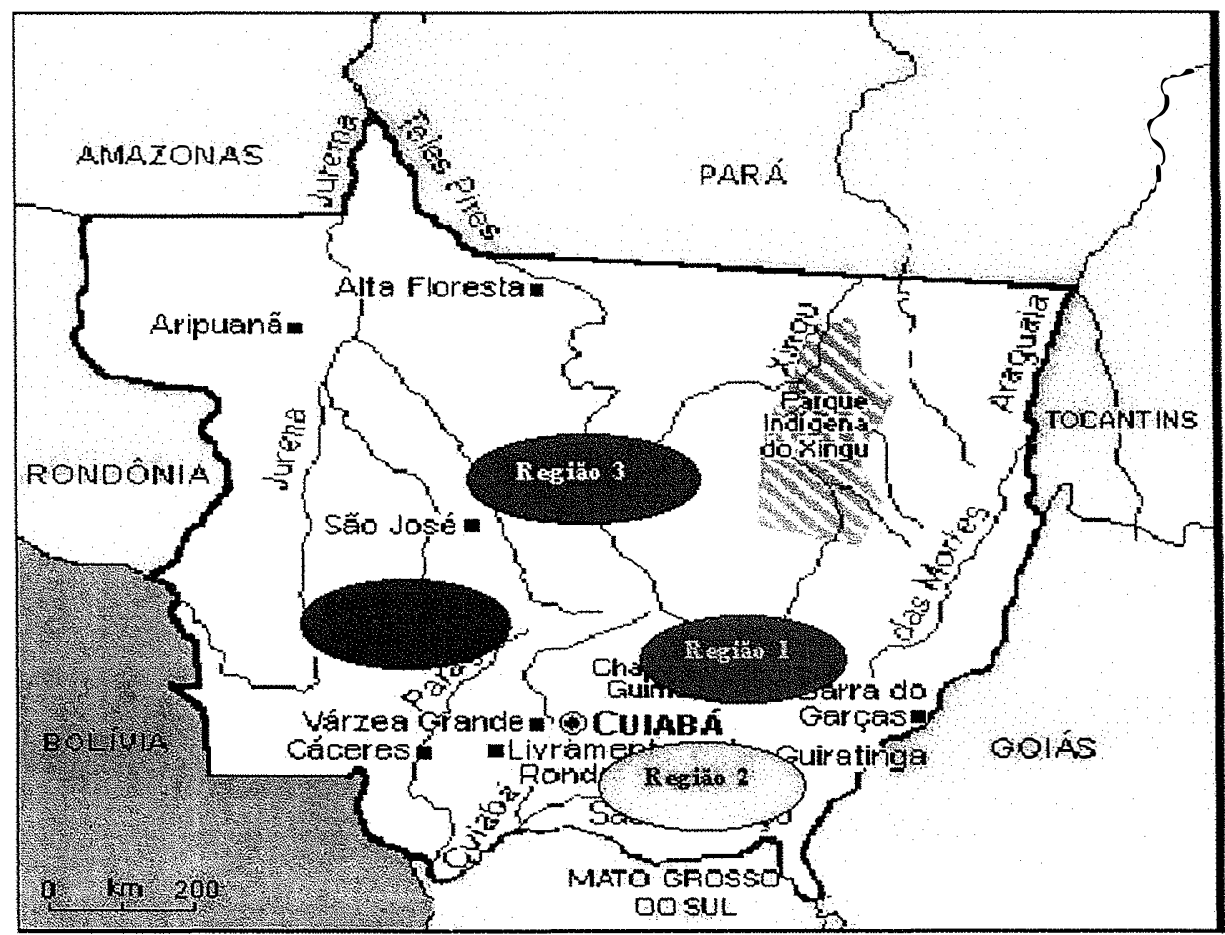

Figura 1- Regiões de produção do estado do Mato Grosso.

Fonte: Resultados da Pesquisa. 
- Região 1: Primavera do Leste, Novo São Joaquim, Campo Verde;

- Região 2: Rondonópolis, Itiquira.

Tratam-se das regiões mais importantes de produção do estado. No geral, merecem destaque três pontos destas regiões: ocupação mais antiga, menores custos de transporte e melhores formas de acesso. Esta área do estado é separada por uma serra que a divide em duas regiões: ao sul, Rondonópolis e Itiquira e ao norte, Primavera do Leste, Novo São Joaquim e Campo Verde. As duas regiões seguem padrões semelhantes, ou seja, as produções de soja, algodão e boi dividem a maior parte das áreas. O sistema de plantio direto é predominante e as condições climáticas são bastante estáveis. O relevo é plano e o rendimento de máquina elevado.

- Região 3: Sorriso, Sinop, Lucas do Rio Verde, Nova Mutum.

Estes municípios ocupam a região central do estado, começando em Diamantino e chegando a Sinop. Parte de uma serra ao sul que se inicia com campos planos de cerrado e segue pela região de transição até chegar na floresta Amazônica. A ocupação é relativamente recente e existem restrições ambientais, com grandes áreas de reserva legal. As dificuldades de escoamento da produção elevam os custos de frete, pois a região é ligada ao restante do país por uma rodovia federal, que une Cuiabá/MT a Santarém/PA. As alternativas de transporte na região ainda são pequenas. A topografia é plana, facilitando a mecanização da atividade agrícola. A excelente distribuição das chuvas também tem sido uma característica marcante.

- Região 4: Sapezal, Campo Novo dos Parecis, Campos de Júlio e Tangará da Serra. 
A região é caracterizada por agregar o maior campo aberto de produção do país, onde o crescimento da produção tem sido muito intenso. A ampliação das áreas de produção ocorre no mesmo ritmo do aumento da produtividade. A região começa a utilizar novas rotas de escoamento da produção, através do terminal intermodal de Itacoatiara, que utiliza os rios Madeira e Amazonas. Isso tem reduzido os custos de escoamento da soja, mas os demais produtos da região ainda dependem do escoamento rodoviário, que é muito problemático.

Tabela 8. Crescimento da área (variação percentual) na década de 90.

\begin{tabular}{lclll}
\hline Região & Soja & Milho & Algodão & Arroz \\
\hline Regiões 1 e 2 & & & & \\
Primavera do Leste - MT & $12 \%$ & $308 \%$ & $2136 \%$ & $-39 \%$ \\
Rondonópolis - MT & $17 \%$ & $67 \%$ & $517 \%$ & $-34 \%$ \\
$\begin{array}{l}\text { Região 3 } \\
\text { Alto Teles Pires - MT }\end{array}$ & $102 \%$ & $746 \%$ & $5062 \%$ & $388 \%$ \\
Sinop - MT & $69 \%$ & $93 \%$ & $-47 \%$ & $47 \%$ \\
Região 4 & & & & \\
Tangará da Serra - MT & $36 \%$ & $-27 \%$ & $-57 \%$ & $-69 \%$ \\
Parecis - MT & $150 \%$ & $34 \%$ & $572 \%$ & $-18 \%$ \\
\hline
\end{tabular}

Fonte: IBGE, 1996.

Tabela 9. Distribuição das culturas e a atividade pecuária nas principais regiões do estado do Mato Grosso.

\begin{tabular}{lcllll}
\hline Região & Soja & Milho & Algodão & Arroz & Bovinos \\
\hline Regiões 1 e 2 & & & & & \\
Primavera do Leste - MT & $10 \%$ & $13 \%$ & $17 \%$ & $2 \%$ & $1 \%$ \\
Rondonópolis - MT & $11 \%$ & $10 \%$ & $25 \%$ & $2 \%$ & $7 \%$ \\
Região 3 & & & & & \\
Alto Teles Pires - MT & $24 \%$ & $19 \%$ & $6 \%$ & $23 \%$ & $3 \%$ \\
Sinop - MT & $1 \%$ & $2 \%$ & $1 \%$ & $5 \%$ & $3 \%$
\end{tabular}


Tabela 9. Distribuição das culturas e a atividade pecuária nas principais regiões do estado do Mato Grosso.

\begin{tabular}{llllll}
\hline Região & Soja & Milho & Algodão & Arroz & Bovinos \\
\hline Região 4 & & & & & \\
Tangará da Serra - MT & $1 \%$ & $3 \%$ & $1 \%$ & $1 \%$ & $4 \%$ \\
Campos N. Parecis - MT & $31 \%$ & $10 \%$ & $13 \%$ & $14 \%$ & $2 \%$ \\
Estado do Mato Grosso & $100 \%$ & $100 \%$ & $100 \%$ & $100 \%$ & $100 \%$ \\
\hline
\end{tabular}

Fonte: IBGE, 1996.

O arroz é utilizado para a abertura de novas áreas, logo após a retirada da vegetação do cerrado. Depois da abertura, a cultura mais comum nas propriedades passa a ser a soja, que tem uma série de facilidades que favorecem o seu cultivo, dentre as quais merecem destaque: os pacotes tecnológicos, que permitem os maiores níveis de produtividade média do país, e o sistema comercial, que proporciona o cultivo com capital de terceiros. Além disso, o clima extremamente previsível também favorece essa cultura, que tem apresentado o menor desvio em relação à produtividade média ao longo dos últimos 10 anos.

A cultura do milho é feita principalmente na época da safrinha, ou seja, após a colheita da soja é feito o plantio do milho, que aproveita os resíduos deixados no solo pela cultura anterior. O milho somente é viável sob essas condições: com baixos custos de plantio e com a colheita fora de época - se comparada a outras regiões. O milho convencional, mesmo com altos níveis de rendimento por área, torna-se inviável devido aos custos de transporte.

O algodão foi introduzido na região como uma cultura economicamente viável no início da década de 90 , quando variedades importadas dos EUA foram plantadas na região de Tangará da Serra, mais especificamente na Fazenda Itamaraty do Norte. As variedades passaram por um intenso processo de adaptação, o que melhorou o rendimento da pluma por área. 
O processo de desenvolvimento da cultura, no entanto, mostrou-se seletivo devido aos elevados custos do maquinário e da produção. Entretanto, à medida que a atividade complementou de forma significativa o portfólio de produção das fazendas, tal processo de desenvolvimento tornou-se irreversível. A cultura apresenta um elevado retorno por área, sendo que em algumas safras a receita líquida chegou a ser 10 vezes maior que a da soja. O grande problema do algodão está nos elevados riscos de produção, pois além dos riscos climáticos - que têm sido pequenos no histórico dos últimos anos -, existem os riscos causados pela infestação de pragas, a qual é controlada por pesados gastos com produtos químicos.

A pecuária extensiva é a atividade mais antiga do estado. Apesar deste aspecto tradicional, esta atividade tem ganho espaço nos últimos anos. No passado, o fator predominante da atividade pecuária era o baixo nível tecnológico e o uso de grandes extensões de terra. Na moderna pecuária, duas formas de trato cultural têm sido comuns: o uso de pastagens cultivadas em áreas de descanso de culturas anuais e a aplicação de técnicas que minimizam os efeitos dos meses de seca.

O uso da terra implica na correção do solo, tanto no que se refere à sua acidez quanto à sua fertilidade. Uma outra forma de correção do solo se dá através do uso de técnicas que possibilitam o aproveitamento das características climáticas da região (temperaturas médias elevadas e dias longos) para a produção de matéria seca, com a utilização de sistemas de irrigação nas pastagens.

\subsubsection{Propriedades típicas}

A propriedade típica do Mato Grosso situa-se num intervalo de 1.000 a 10.000 hectares. As propriedades menores são mais comuns nas regiões de ocupação antiga, como nas proximidades de Rondonópolis e Primavera do Leste. Nas áreas de ocupação 
mais recente, como Sorriso e Sapezal, as propriedades possuem áreas maiores. A vantagem das grandes propriedades está no poder de barganha, tanto na compra dos insumos quanto na venda dos produtos. Em geral, as propriedades mato-grossenses têm uma estrutura de produção concentrada nos seguintes produtos: soja, milho, algodão e pecuária de corte. Em menor escala, aparece a cultura do arroz, conforme atestam as tabelas de 10 a 13 .

Tabela 10. Grupos de área total e sua utilização na Região 1 (Primavera do Leste/MT).

\begin{tabular}{llllll}
\hline Grupos de área (ha) & Algodão & Arroz & Milho & Soja & Pastagem \\
\hline Menos de 10 & $0 \%$ & $0 \%$ & $1 \%$ & $1 \%$ & $0 \%$ \\
10 a menos de 100 & $0 \%$ & $0 \%$ & $0 \%$ & $0 \%$ & $2 \%$ \\
100 a menos de 1.000 & $0 \%$ & $31 \%$ & $30 \%$ & $25 \%$ & $19 \%$ \\
1.000 e mais & - & - & - & - & $56 \%$ \\
1.000 a menos de 10.000 & $17 \%$ & $58 \%$ & $63 \%$ & $67 \%$ & - \\
10.000 e mais & $83 \%$ & $11 \%$ & $6 \%$ & $7 \%$ & - \\
Sem declaração & $0 \%$ & $0 \%$ & $0 \%$ & $0 \%$ & $0 \%$ \\
\hline
\end{tabular}

Fonte: IBGE, 1996.

Tabela 11. Grupos de área total e sua utilização na Região 2 (Rondonópolis/MT).

\begin{tabular}{llllll}
\hline Grupos de área (ha) & Algodão & Arroz & Milho & Soja & Pastagem \\
\hline Menos de 10 & $2 \%$ & $1 \%$ & $0 \%$ & $0 \%$ & $1 \%$ \\
10 a menos de 100 & $11 \%$ & $4 \%$ & $2 \%$ & $0 \%$ & $9 \%$ \\
100 a menos de 1.000 & $29 \%$ & $20 \%$ & $19 \%$ & $20 \%$ & $38 \%$ \\
1.000 e mais & - & - & - & - & $52 \%$ \\
1.000 a menos de 10.000 & $58 \%$ & $20 \%$ & $66 \%$ & $68 \%$ & - \\
10.000 e mais & $0 \%$ & $55 \%$ & $12 \%$ & $12 \%$ & - \\
Sem declaração & $0 \%$ & $0 \%$ & $0 \%$ & $0 \%$ & $1 \%$ \\
\hline
\end{tabular}

Fonte: IBGE,1996. 
Tabela 12. Grupos de área total e sua utilização na Região 3 (Lucas do Rio Verde e Sorriso/MT).

\begin{tabular}{llllll}
\hline Grupo de área (ha) & Algodão & Arroz & Milho & Soja & Pastagem \\
\hline Menos de 10 & $0 \%$ & $0 \%$ & $0 \%$ & $0 \%$ & $0 \%$ \\
10 a menos de 100 & $4 \%$ & $5 \%$ & $2 \%$ & $0 \%$ & $4 \%$ \\
100 a menos de 1.000 & $0 \%$ & $34 \%$ & $47 \%$ & $37 \%$ & $42 \%$ \\
1.000 e mais & - & - & - & - & $40 \%$ \\
1.000 a menos de 10.000 & $96 \%$ & $56 \%$ & $46 \%$ & $60 \%$ & - \\
10.000 e mais & $0 \%$ & $5 \%$ & $6 \%$ & $3 \%$ & - \\
Sem declaração & $0 \%$ & $0 \%$ & $0 \%$ & $0 \%$ & $14 \%$ \\
\hline
\end{tabular}

Fonte: IBGE, 1996.

Tabela 13. Grupos de área total e sua utilização na Região 4 (Parecis/MT).

\begin{tabular}{llllll}
\hline Grupo de área (ha) & Algodão & Arroz & Milho & Soja & Pastagem \\
\hline Menos de 10 & $0 \%$ & $0 \%$ & $0 \%$ & $0 \%$ & $1 \%$ \\
10 a menos de 100 & $0 \%$ & $2 \%$ & $2 \%$ & $0 \%$ & $4 \%$ \\
100 a menos de 1.000 & $0 \%$ & $6 \%$ & $5 \%$ & $8 \%$ & $15 \%$ \\
1.000 e mais & - & - & - & - & $62 \%$ \\
1.000 a menos de 10.000 & $0 \%$ & $81 \%$ & $68 \%$ & $70 \%$ & - \\
10.000 e mais & $100 \%$ & $11 \%$ & $24 \%$ & $22 \%$ & - \\
Sem declaração & $0 \%$ & $0 \%$ & $0 \%$ & $0 \%$ & $1 \%$ \\
\hline
\end{tabular}

Fonte: IBGE, 1996.

Os dados do IBGE mostram que as unidades de produção no Mato Grosso possuem áreas agrícolas maiores que nos demais estados do país. As características de topografia, solo e forma de manejo contribuem para o melhor desempenho em áreas maiores. O IBGE revela também que a produção de algodão é mais comum nas propriedades maiores. Isso pode ser justificado pelo fato de que é uma cultura que demanda de grandes investimentos, o que inviabiliza pequenos plantios. 
As informações disponíveis no IBGE, não permitem que se construa uma propriedade típica para o estado. Para suprir tal deficiência, foram realizados painéis que subsidiam a construção do modelo típico de propriedade da região.

A seguir estão apresentados os dados das propriedades definidas em três painéis realizados no estado: Sorriso, Tangará da Serra e Rondonópolis.

Tabela 14. Propriedade típica em Sorriso/MT, em hectares.

\begin{tabular}{ll}
\hline Uso & Área (ha) \\
\hline Área agrícola & 1200 \\
Algodão & 400 \\
Arroz & 0 \\
Milho plantio convencional & 0 \\
Milho plantio direto & 0 \\
Milho safrinha & 500 \\
Soja plantio convencional & 100 \\
Soja plantio direto & 700 \\
Pecuária & 1000 \\
\hline
\end{tabular}

Fonte: Resultados da pesquisa.

Tabela 15. Propriedade típica de Tangará da Serra/MT, em hectares.

\begin{tabular}{ll}
\hline Uso & Área (ha) \\
\hline Área agrícola & 2000 \\
Algodão & 400 \\
Arroz & 0 \\
Milho plantio convencional & 0 \\
Milho plantio direto & 0 \\
Milho safrinha & 150 \\
Soja plantio convencional & 300 \\
Soja plantio direto & 1050 \\
Pecuária & 1000 \\
\hline
\end{tabular}

Fonte: Resultados da pesquisa. 
Tabela 16. Propriedade típica de Rondonópolis/MT, em hectares.

\begin{tabular}{ll}
\hline Uso & Área (ha) \\
\hline Área agrícola & 1500 \\
Algodão & 400 \\
Arroz & 0 \\
Milho plantio convencional & 0 \\
Milho plantio direto & 0 \\
Milho safrinha & 200 \\
Soja plantio convencional & 0 \\
Soja plantio direto & 1100 \\
Pecuária & 1000 \\
\hline
\end{tabular}

Fonte: Resultados da pesquisa.

As três regiões têm estruturas relativamente semelhantes, ou seja, a maior parte das receitas é proveniente das culturas de soja, algodão e milho. Também é comum a existência de uma produção pecuária, que pode estar na mesma propriedade ou em outra. No entanto, é importante destacar que a receita dessa atividade faz parte da receita total do produtor.

A propriedade típica a ser analisada é a da região de Tangará da Serra, ou seja, é uma propriedade que tem uma área agrícola de 2.000 hectares, sendo que possuem uma área de 400 hectares de algodão e 1.350 hectares de soja. Desta forma, a cultura de algodão ocupa uma área equivalente a $30 \%$ da soja. Essa proporção está dentro do recomendado pelos técnicos independentes que prestam assistência na região, os quais recomendam uma composição de até $35 \%$ da área com algodão. 


\subsubsection{Fluxos de caixa}

A seguir é feita, com base nos dados dos painéis, uma análise dos fluxos financeiros da propriedade, uma vez que a definição das atividades da propriedade leva em conta a estrutura financeira dos desembolsos do produtor.

A Figura 2 apresenta a estrutura dos pagamentos da propriedade por atividade. O mês de abril tem um grande desembolso com a cultura da soja. Isto ocorre por ser o mês do vencimento dos financiamentos dos insumos. No final do ano, em outubro e novembro, também ocorrem desembolsos com a cultura da soja, são os pagamentos das atividades de plantio, cultivo e manutenção da cultura.

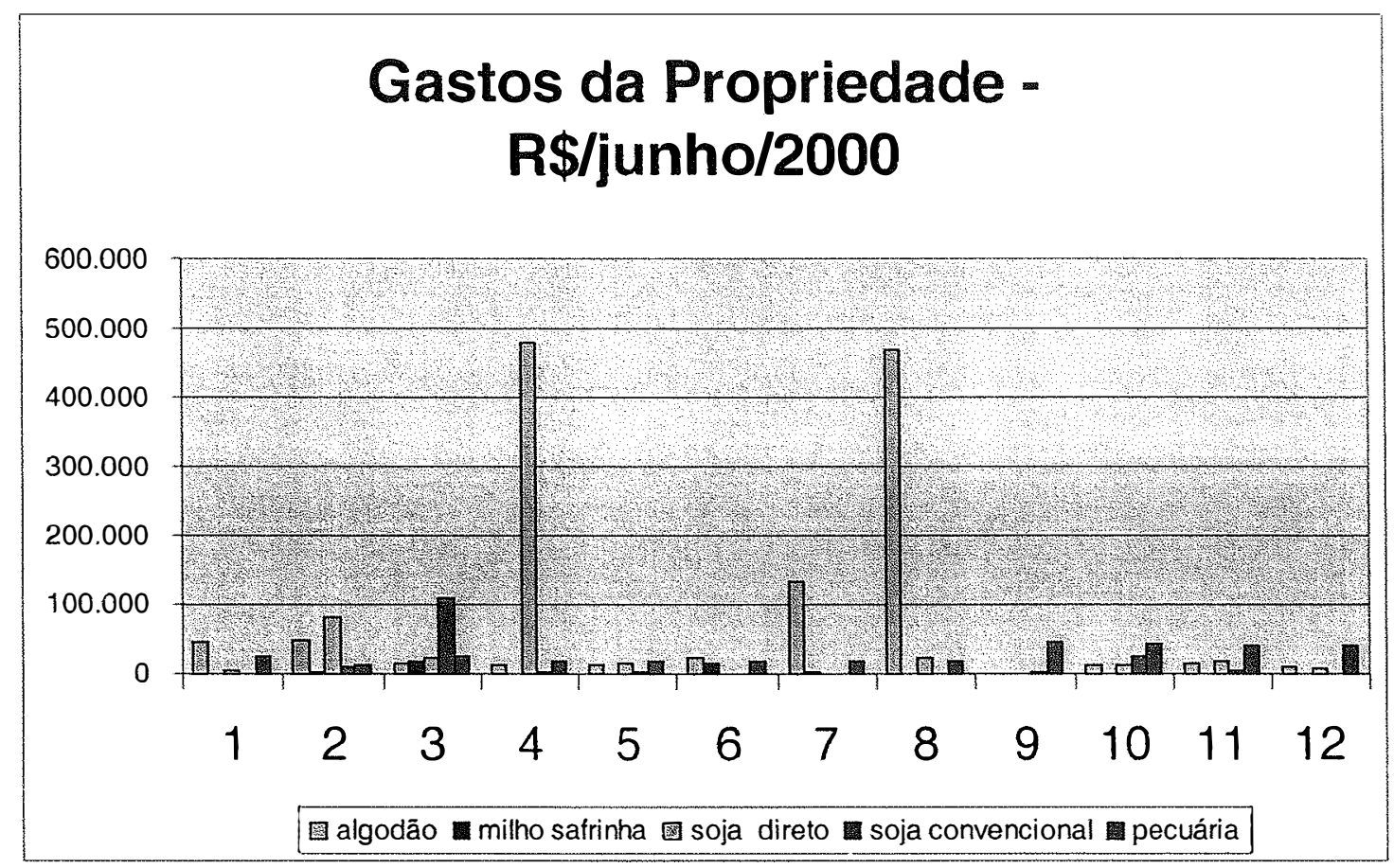

Figura 2 - Gastos de uma propriedade com os principais produtos produzidos. Fonte: Resultados da pesquisa.

O algodão tem uma forte concentração dos gastos de seus insumos nos meses de julho e agosto, e dos tratos culturais nos meses de outubro a fevereiro. 
As outras atividades, milho e pecuária de corte, não têm grandes gastos mensais. A pecuária tem desembolsos mensais quase constantes. Sendo que, no segundo semestre, as atividades ecuárias incluem a reforma de pastagem e nesta época os gastos sofrem uma pequena elevação.

A Figura 3 apresenta os dados das receitas da propriedade por produto. No geral, a propriedade típica apresenta uma maior concentração das receitas no segundo semestre.

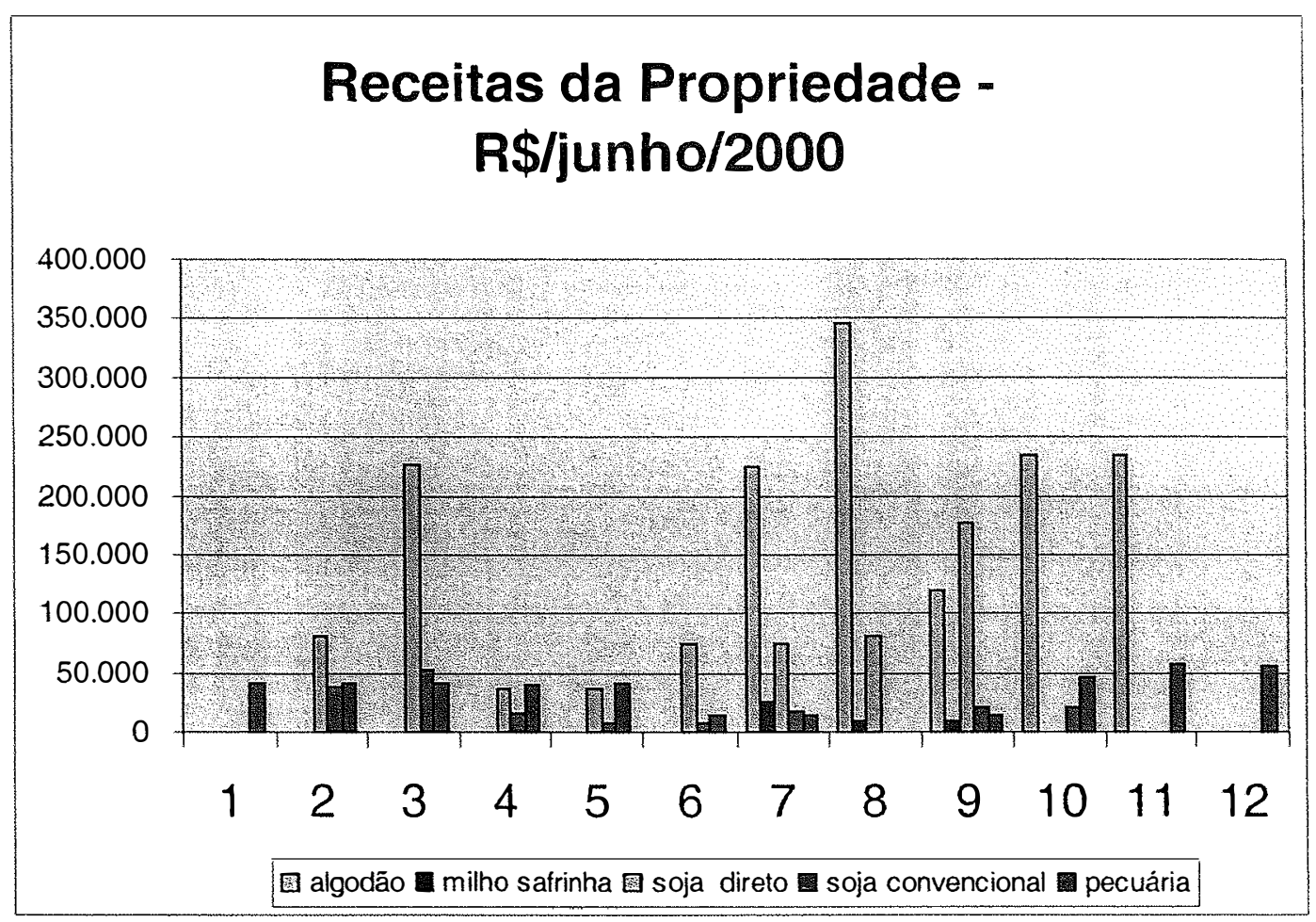

Figura 3 - Receitas de uma propriedade por produto, em reais; junho/2000. Fonte: Resultados da pesquisa.

O algodão é o produto que gera o maior volume de movimentação financeira. A comercialização deste produto tem o início em julho e o encerramento ocorre em novembro. A soja inicia a safra e também a comercialização em fevereiro, sendo que o volume comercializado aumenta em março com a finalidade de fazer caixa para o 
pagamento dos insumos. O restante da produção tem a venda parcelada nos meses seguintes, sendo que até setembro toda a produção já está comercializada. A comercialização do produto é mais espaçada pelo fato de possuir grande liquidez.

A comercialização do algodão concentra-se no segundo semestre, logo após a colheita, período em que este produto gera grandes receitas (entre julho e novembro). Já o milho gera receitas nos meses de julho e agosto, sendo, esta cultura, utilizada principalmente como uma forma de cobertura da terra.

A pecuária é tratada como uma atividade separada do restante da fazenda. Seus custos são pequenos e as receitas seguem a disponibilidade de pastagens. De novembro a maio a comercialização de animais é maior que no restante do ano, coincidindo com a disponibilidade de alimento.

\section{Saldos da propriedade - todas as atividades - R\$ jun/2000}

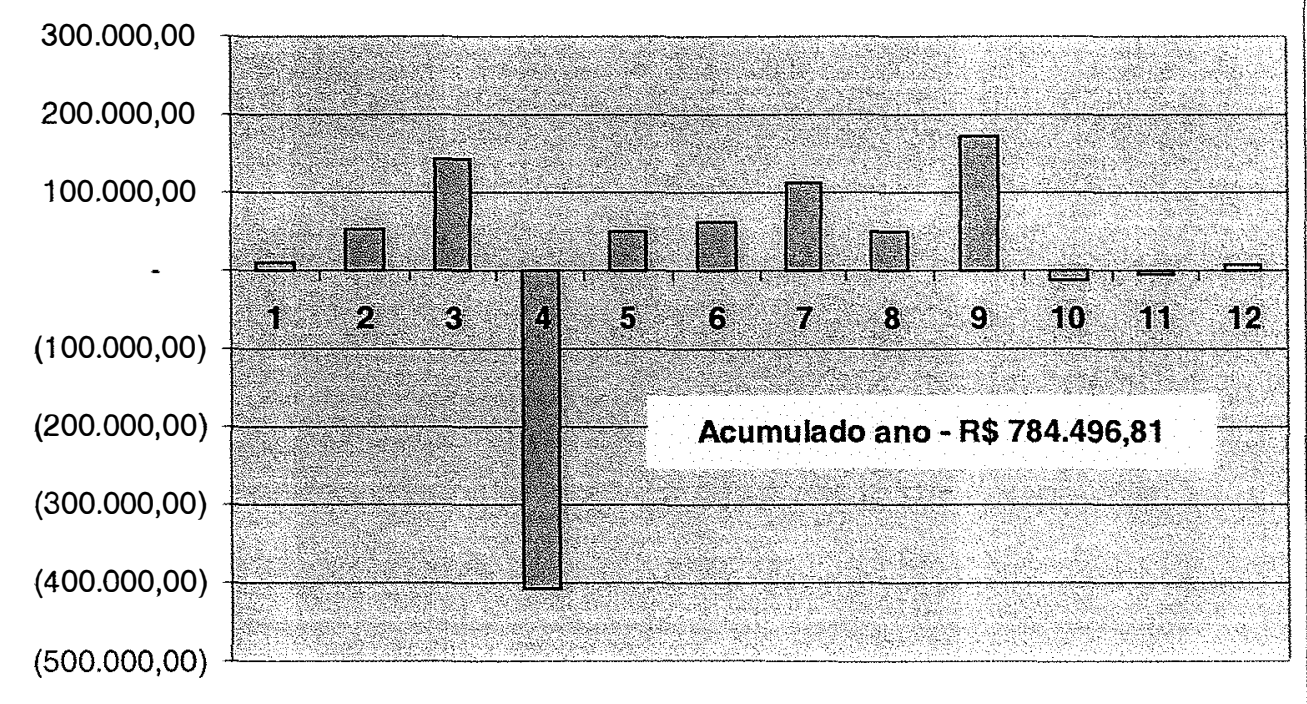

Figura 4 - Saldos (em reais) de uma propriedade em Tangará da Serra incluindo todas as atividades; julho/2000.

Fonte: Resultados da pesquisa. 
$\mathrm{Na}$ Tabela 17 está apresentado o inventário de equipamentos e benfeitorias necessários para as atividades agrícolas de uma propriedade típica do Mato Grosso. Neste quadro não estão considerados os valores das instalações necessárias às atividades ligadas à pecuária.

Tabela 17. Investimentos (máquinas, implementos, benfeitorias e outros) de uma propriedade típica do Mato Grosso.

\begin{tabular}{llll}
\hline Item & Quantidade & Valor inicial & Total \\
\hline Trator traçado & 2 & $70.000,00$ & $140.000,00$ \\
Trator pequeno & 2 & $28.000,00$ & $56.000,00$ \\
Plantadeira & 2 & $25.000,00$ & $50.000,00$ \\
Colheitadeira TC 59 & 2 & $159.000,00$ & $318.000,00$ \\
Pulverizador Vortex & 2 & $38.000,00$ & $76.000,00$ \\
Plantadeira convencional & 1 & $15.000,00$ & $15.000,00$ \\
Caminhão & 1 & $50.000,00$ & $50.000,00$ \\
"Pick up" & 1 & $40.000,00$ & $40.000,00$ \\
Grade aradora & 1 & $18.000,00$ & $18.000,00$ \\
Grade niveladora & 1 & $12.000,00$ & $12.000,00$ \\
Tanque de água & 1 & $5.000,00$ & $5.000,00$ \\
Calcareadeira & 1 & $8.000,00$ & $8.000,00$ \\
Vicon & 1 & $5.000,00$ & $5.000,00$ \\
Galpão & 1 & $20.000,00$ & $20.000,00$ \\
Poço artesiano & 1 & $10.000,00$ & $10.000,00$ \\
Tanque de óleo & 1 & $1.500,00$ & $1.500,00$ \\
Casas & 2 & $10.000,00$ & $20.000,00$ \\
Roçadeira & 1 & $3.000,00$ & $3.000,00$ \\
Energia & 1 & $6.000,00$ & $6.000,00$ \\
Determinador de umidade & 1 & $2.500,00$ & $2.500,00$ \\
Estrada & 20 & 300,00 & $6.000,00$ \\
Oficina & 1 & $15.000,00$ & $15.000,00$ \\
Caixa-d'água & 1 & $3.000,00$ & $3.000,00$ \\
Telefone & $1.500,00$ & $1.500,00$ \\
& & &
\end{tabular}


Tabela 17. Investimentos (máquinas, implementos, benfeitorias e outros) de uma propriedade típica do Mato Grosso.

\begin{tabular}{llll}
\hline Item & Quantidade & Valor inicial & Total \\
\hline Plataforma de milho & 1 & $15.000,00$ & $15.000,00$ \\
$\begin{array}{l}\text { Outros } \\
\text { Total de benfeitorias e }\end{array}$ & 1 & $20.000,00$ & $20.000,00$ \\
equipamentos & & & $916.500,00$ \\
\hline
\end{tabular}

Fonte: CEPEA - ESALQ/USP, 2000.

O valor total dos investimentos nessa propriedade corresponde a aproximadamente R $\$ 916$ mil. Esse investimento é, em sua grande maioria, custeado por empréstimos do Finame, ou seja, dinheiro público. De acordo com os painéis, esses equipamentos são superdimensionados para a atividade e, por esse motivo, não são incluídos nas regressões do modelo matemático.

\subsection{Rio Grande do Sul}

Este estado tem relevância na cultura da soja e do milho, mas a estrutura de produção é muito diferente da mato-grossense. As características climáticas diferenciam as estruturas agrícolas deste estado daquelas encontradas no Mato Grosso. O "mix" de produção do estado tem produtos que não são commodities, como as frutas, que estão concentradas em regiões diferentes das ocupadas por milho e soja do estado. 
Tabela 18. Produção e participação do Rio Grande do Sul no total produzido em 98/99.

\begin{tabular}{llll}
\hline Produto & Produção estadual & Participação no Brasil & Posição \\
\hline Carne Bovina & 314,7 mil toneladas & $8,6 \%$ & $5^{\circ}$ \\
(Boi) & $(13,22$ milhões de cabeças $)$ & $(8,3 \%)$ & $\left(5^{\circ}\right)$ \\
Milho safra & $3.723,2$ mil toneladas & $12,2 \%$ & $3^{\circ}$ \\
Soja & $4.764,4$ mil toneladas & $15,5 \%$ & $3^{\circ}$ \\
Arroz & $5.630,77$ mil toneladas & $47,78 \%$ & $1^{\circ}$ \\
\hline
\end{tabular}

Fonte: IBGE.

A região agrícola do estado fica no oeste, onde se concentra a produção de soja e milho. O arroz é produzido na região sul do estado. A estrutura fundiária do Rio Grande do Sul é muito diferente da mato-grossense, sendo que as pequenas áreas respondem por grande parte da produção.

Tabela 19. Produção por estrato de área (ha), noroeste do RS.

\begin{tabular}{lllll}
\hline Região & Grupo de área & Bovinos & Milho & Soja \\
\hline \multirow{4}{*}{ Noroeste } & Menos de 10 & $17 \%$ & $11 \%$ & $4 \%$ \\
& 10 a menos de 100 & $71 \%$ & $63 \%$ & $52 \%$ \\
& 100 a menos de 1000 & $10 \%$ & $26 \%$ & $43 \%$ \\
& 1000 a menos de 10000 & $2 \%$ & 0,04 & 0,01 \\
& 10000 e mais & - & 0,04 & 0,01 \\
\hline
\end{tabular}

Fonte: IBGE, 1996.

Os dados agregados não permitem a análise da unidade típica de produção da região, mas é possível dizer que o estado tem muitas opções de atividades agrícolas que o distinguem do Mato Grosso. As opções de diversificação no RS são favorecidas. 


\subsubsection{Região de Carazinho - RS}

A região de Carazinho, localizada no planalto médio, centro-norte do Rio Grande do Sul, destaca-se como a principal região produtora de grãos do estado. As propriedades têm em média 150-200 hectares e a atividade agrícola está baseada na produção de soja, milho, trigo e pecuária. O sistema de cultivo predominante utilizado na região é o plantio direto.

Beneficiados por estarem localizados em solos férteis, com altos teores de matéria orgânica e também por se manterem atentos e abertos às novas tecnologias, os produtores de Carazinho têm sua média de produtividade da soja $23 \%$ superior à média estadual.

O trabalho de coleta dos dados das propriedades gaúchas deu-se da seguinte maneira: na primeira visita a Carazinho, dois produtores foram selecionados com a colaboração de um técnico, que já trabalha no local há 25 anos e que, portanto, tem grande conhecimento do setor agrícola na região. Com o objetivo de fazer uma amostragem dos demais produtores da região, esses dois foram selecionados por serem representativos, com propriedades entre 150 e 200 ha e com atividades baseadas no cultivo de soja, milho e trigo em plantio direto. Algumas informações primárias sobre a estrutura de funcionamento de suas unidades agrícolas foram fornecidas por esses produtores e, com base nestas informações, foram elaboradas planilhas de custos e fluxo de caixa.

Estas planilhas, num segundo momento, foram apresentadas aos dois produtores que acrescentaram e homogeneizaram os resultados, possibilitando um enriquecimento e tornando as planilhas mais abrangentes.

Numa terceira etapa, outra reunião foi realizada, na qual, além dos pesquisadores e do técnico, participou um grupo de seis produtores da região. A elaboração de custos e fluxo de caixa com base em informações técnicas da região e a discussão em grupo desses dados, de maneira a obter um consenso, são uma forma de aproximar a pesquisa 
do produtor. Este agente participa do processo e sente-se dono e co-responsável pelas informações. A discussão em grupo força os participantes a expressarem os seus pontos de vistas.

Através desta dinâmica, ficou evidente que é consenso entre os produtores o sentimento de carência em relação a uma estrutura de controle de custos de suas propriedades. O produtor rural passa por dificuldades para saber quais as atividades são mais rentáveis dentro de sua unidade de produção. Da mesma forma, os fornecedores de crédito também desconhecem a atividade.

\subsubsection{Propriedades típicas}

O processo de pesquisa supõe a definição de um modelo de propriedade típica (veja tabela abaixo), ou seja, a definição de uma unidade de produção que represente a região como um todo. Neste modelo de propriedade é possível verificar os efeitos da adoção da nova tecnologia (soja transgênica) sobre o caixa da propriedade.

Tabela 20. Modelo de propriedade típica em Carazinho/RS; área em hectares.

\begin{tabular}{ll}
\hline Cultura & Área (ha) \\
\hline Soja (plantio direto) & 95 \\
Milho & 75 \\
Trigo & 56 \\
Pecuária & 20 \\
\hline
\end{tabular}

Fonte: Resultados da pesquisa.

A área de cada cultura permite a definição da alocação dos recursos disponíveis dentro da fazenda. No entanto, o saldo líquido de cada uma das culturas fornece o 
resumo do resultado financeiro da propriedade. Os resultados da safra atual estão apresentados na Figura 5:

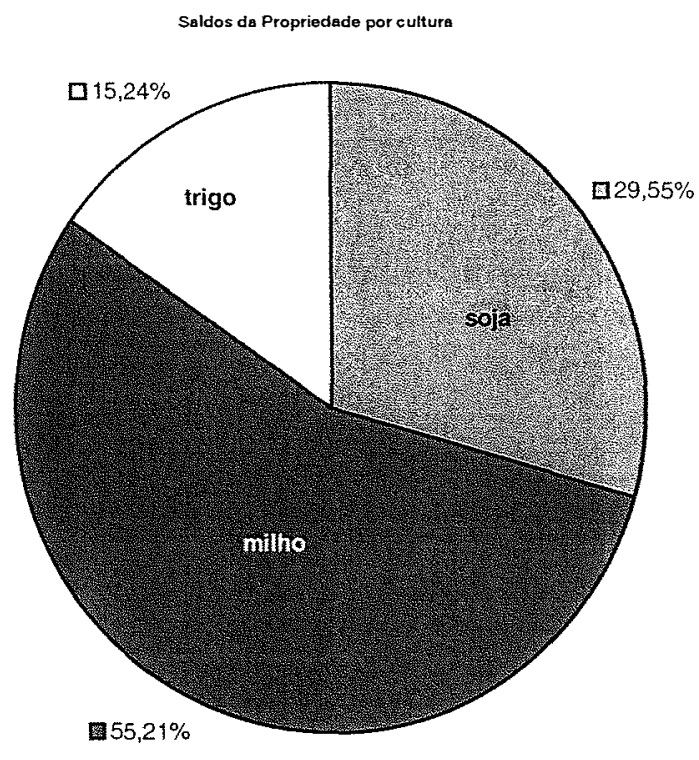

Figura 5 - Saldos da propriedade por cultura.

Fonte: Resultados da pesquisa.

$\mathrm{Na}$ última safra, os preços do milho foram elevados e, por este motivo, a receita financeira dessa cultura superou a da soja, mesmo considerando-se o fato de que a área de soja foi 20 hectares maior que a de milho.

O processo comercial desses produtores foi fácil nesta última safra, pois os preços favoráveis da soja, milho e trigo permitiram uma forte capitalização dos produtores. Nessas condições, os produtores podem escalonar a comercialização de forma mais favorável.

O conhecimento dessa propriedade é fundamental para o estudo dos impactos que a adoção da soja transgênica pode ocasionar na área ocupada e os motivos que levam os produtores a adotar essa tecnologia. 


\subsubsection{Fluxo de caixa da propriedade}

Os produtores têm pouco conhecimento sobre o fluxo monetário de suas atividade dentro de uma propriedade. No entanto, a definição das atividades e, mesmo a adoção de tecnologias depende desse fluxo. O produtor busca alternativas para as atividades possíveis dentró da sua área e a soja transgênica representa mais uma alternativa dentro do portfólio de produtos da fazenda.

A seguir é apresentada uma análise do fluxo financeiro de uma propriedade, com base nos dados levantados durante o painel.

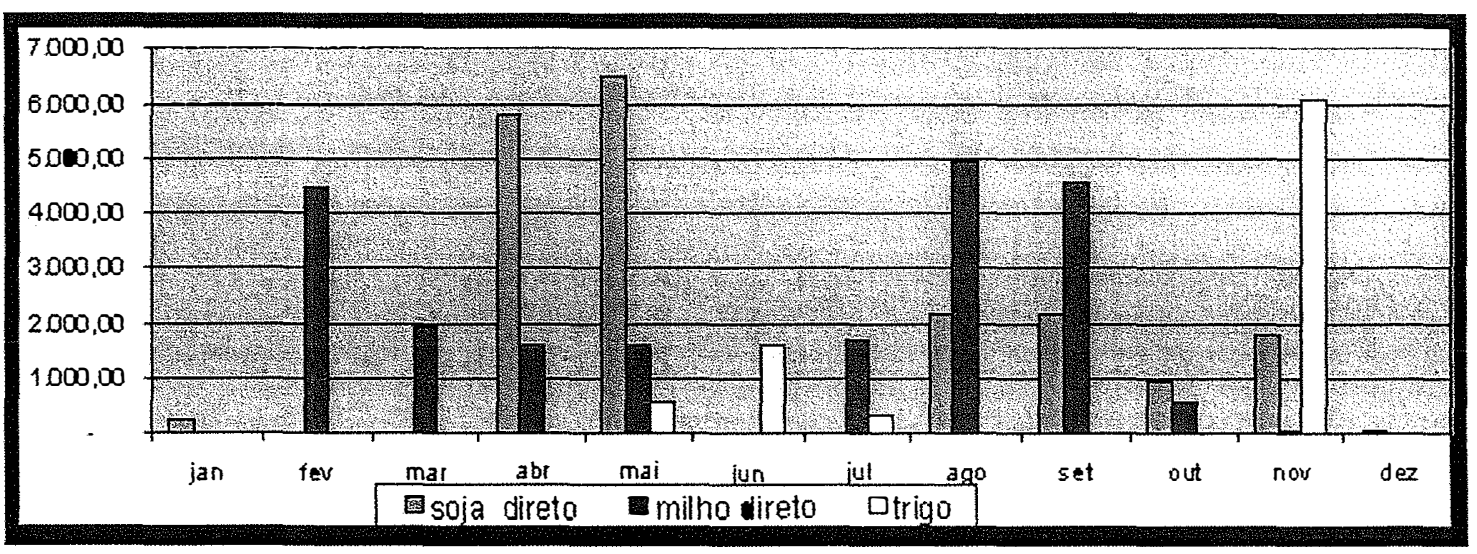

Figura 6 - Fluxo das despesas por cultura - Carazinho/RS.

Fonte: Resultados da pesquisa.

Nota-se que o fluxo de despesas das propriedades gaúchas é mais equilibrado que o das propriedades do Mato Grosso. Os maiores desembolsos se concentram em abril e maio, quando são pagos os insumos da soja, o que evidencia que a soja conta com 
créditos das empresas de insumos. Tal relacionamento não se verifica para a cultura do milho, pois, nesta atividade, o produtor faz os dispêndios no período de plantio (agosto e setembro). Para o trigo também não há financiamento por parte das indústrias de insumos.

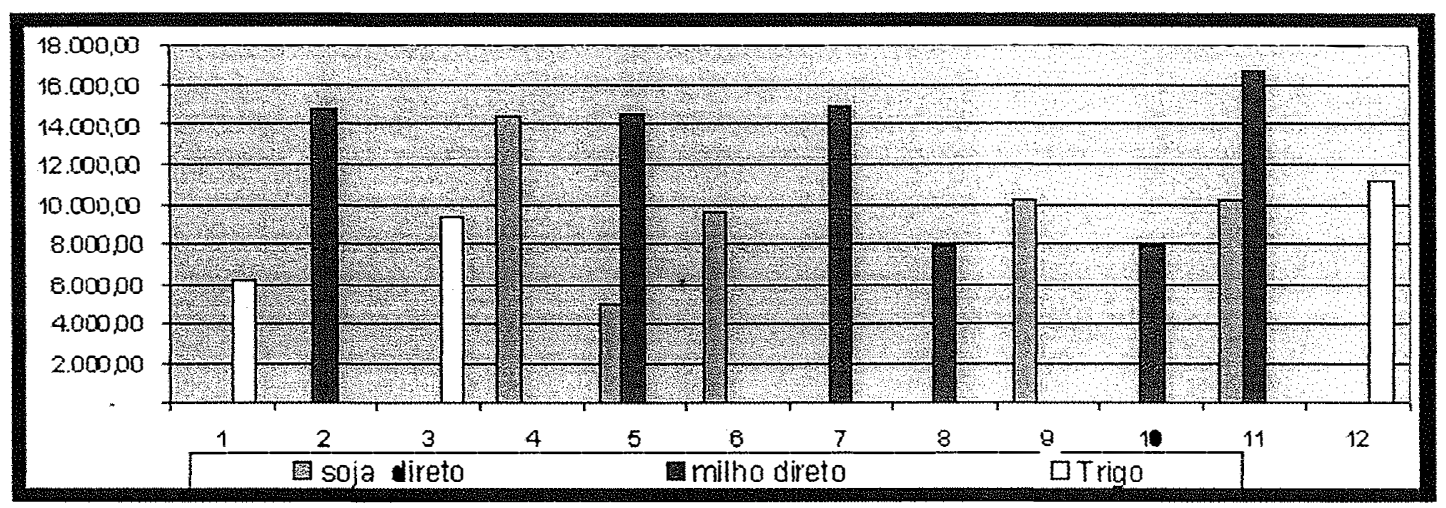

Figura 7 - Fluxos das receitas por cultura - Carazinho/RS.

Fonte: Resultados da pesquisa.

Na Figura 7 estão apresentadas as receitas dos produtores gaúchos. Verificase que o produtor procura parcelar as vendas de seus produtos ao longo do ano. De maneira geral, uma parcela é colocada no mercado na safra e o restante é ofertado ao longo do ano.

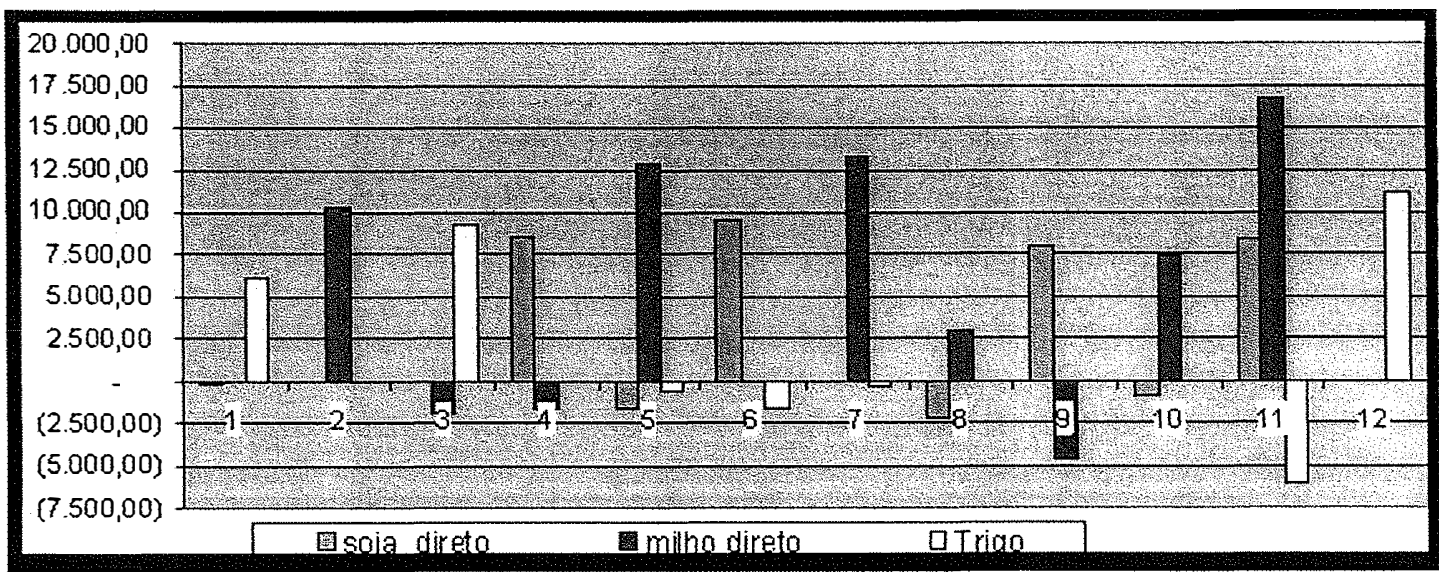

Figura 8 - Fluxo dos saldos por cultura - Carazinho/RS.

Fonte: Resultados da pesquisa. 
O fluxo de caixa das propriedades típicas do Rio Grande do Sul apresentado na Figura 8 mostra que os produtores dessa região não têm grandes pontos de estrangulamento financeiros. Esta condição será muito importante na construção das restrições do modelo matemático.

O cultivo da soja geneticamente modificada, apesar de ser uma prática legalmente proibida, tem se tornado uma alternativa cada vez mais adotada pelos produtores da região. Entrando no quinto ano de cultivo, estima-se que na próxima safra $60 \%$ dos produtores gaúchos usem esta tecnologia. Com base nas informações fornecidas por estes produtores gaúchos, foi possível simular o fluxo de caixa desta opção de cultivo. 


\section{METODOLOGIA}

\subsection{Descrição do modelo}

O modelo parte, na sua primeira fase, da maximização da renda do produtor. Isto equivale a dizer que os produtores são indivíduos que se comportam de maneira insensível ao risco. Desta forma, utilizando um modelo de maximização, obtém-se o ponto de máxima receita líquida de um produtor que opte pelas atividades de maior retorno.

No entanto, esse comportamento não é condizente com a realidade dos produtores rurais. No sentido de aperfeiçoar o modelo, são considerados os riscos da receita bruta das atividades em relação ao esperado. Com isto, o modelo passa a captar os efeitos das frustrações de safra e do comportamento dos preços. Supõe-se que as decisões dos produtores sejam tomadas com base nas experiências passadas, representadas pela série de receita bruta da propriedade.

Dessa forma, num plano formado pela receita e pelo risco, é possível construir uma curva onde o produtor troca receita por menor variabilidade da renda. A medida do risco pode ser feita de duas maneiras distintas: através dos desvios absolutos, que linearizam a solução, ou utilizando a variância.

Através da programação matemática, é possível construir a "fronteira eficiente", ou seja, o conjunto de pontos que representam a obtenção da máxima eficiência dentro as combinações de atividades disponíveis. 


\subsection{Modelos de otimização em condições de risco}

Conforme Gass (1969), o modelo de Programação Linear pode ser simbolizado por:

Maximizar:

$\mathbf{Z}=\mathbf{f}^{\prime} \mathbf{x}$

Sujeito a:

$\mathbf{A x} \leq \mathbf{b}$

$\mathrm{e}$

$\mathbf{x} \geq \mathbf{0}$

onde $\mathbf{Z}$ é um escalar representando a margem bruta total; $\mathbf{f}$ é um vetor de margens brutas; $\mathbf{x}$ é o vetor de atividades; A é a matriz dos coeficientes técnicos e $\mathbf{b}$ um vetor de restrições físicas e financeiras.

A função objetivo, $\mathbf{Z}$, é o produto do vetor $\mathbf{f}$ (coluna) das margens brutas das diversas culturas pelo vetor $\mathbf{x}$ (coluna) das atividades. O vetor $\mathbf{f}$ inclui receitas das atividades da propriedade, tais como venda de algodão, milho, soja, gado de corte, juros de aplicações financeiras etc. Estes valores (receitas) correspondem a elementos com sinais positivos. Todas as despesas, tais como a compra de insumos, os juros de empréstimos contraídos etc., correspondem a elementos com sinais negativos.

Neste modelo, verifica-se a combinação de atividades que maximizam o lucro, admitindo-se implicitamente que o agricultor é indiferente ao risco. O objetivo do 
produtor, neste caso, é otimizar as receitas da propriedade independente das possibilidades de frustrações de produção e preços, ou de ambos.

Um modelo modificado é proposto para o estudo da propriedade sob condições de incerteza. O novo modelo é proposto com a finalidade de determinar a fronteira de esperança e variância, que mostra as alternativas de troca entre lucro e risco. Para a construção deste modelo, utiliza-se o proposto por Hazell (1971) - Minimization of Total Absolute Deviation (MOTAD) derivado do modelo de média-variância desenvolvido por Markowitz (1952). O modelo pressupõe que o tomador de decisão escolha a alternativa que apresente menor variância, para uma dada média, ou a alternativa com maior média, dado um nível de variância.

O modelo original proposto por Markowitz (1952) pode ser escrito da seguinte maneira:

$V=\sum_{j \mathrm{k}=1}^{\mathrm{n}} \mathrm{X}_{\mathrm{j}}^{\prime} \sigma_{j k} X_{\mathrm{k}}$

Sujeito às seguintes restrições

$\sum a_{i j} x_{j}+\sum a_{j k} x_{k} \leq b_{i}$

$\sum c_{j} x_{j}+\sum c_{k} x_{k}=E$

$x_{j} \geq 0$ e $x_{k} \geq 0$ 
Onde:

V - variância total do resultado econômico das atividades;

$\mathrm{x}_{\mathrm{j}}$ e $\mathrm{x}_{\mathrm{k}}$ - níveis das atividades $\mathrm{j}$ e $\mathrm{k}$;

$\sigma_{j k}$ - covariância entre os retornos das atividades j e k., quando são atividades diferentes.

Quando ambas são a mesma atividade, trata-se da variância;

$\mathrm{b}_{\mathrm{i}}$ - disponibilidade do recurso $\mathrm{i}$;

$\mathrm{c}_{\mathrm{j}}$ e $\mathrm{c}_{\mathrm{k}}$ - resultados Econômicos por unidade das atividades j e k; e

E - resultado econômico esperado.

Segundo Peres (1976), o modelo assume que as variáveis não são estocásticas. O modelo determinístico assume que o critério de escolha é apenas o da receita esperada, o que pode ser considerado uma falha do modelo.

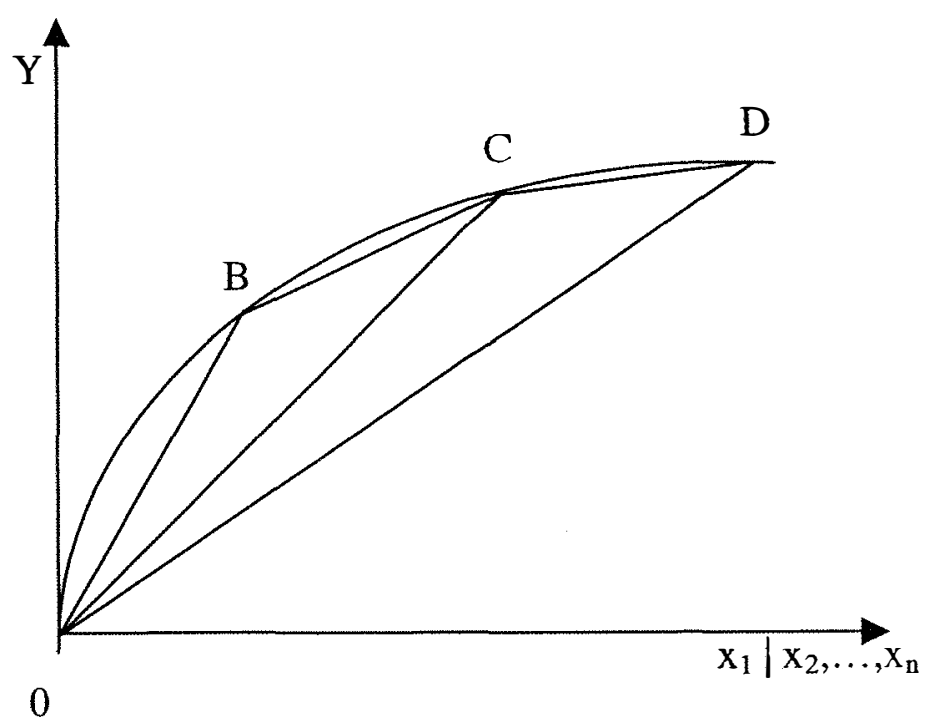

Figura 9 - Segmentação de mercado. 
A limitação deste modelo está no processo de segmentação da função de produção como forma de aproximar do resultado final, conforme ilustrado no gráfico acima.

Segundo Silva (2000), o modelo de Markowitz (1952) foi desenvolvido para os produtos do mercado financeiro, por isto trata os desvios de forma aleatória. Num modelo agrícola, a utilização desse modelo deve ser feita observando as características especiais da atividade, uma vez que o retorno de atividades agrícolas pode apresentar, de alguma forma, tendência devido a características próprias da agropecuária. Assim, ganhos de produtividade, modificações do sistema de produção etc. podem conferir distorções a uma análise, já que esses elementos introduzem tendência à série.

O modelo proposto por Hazell (1971) consiste em:

Minimizar:

$\frac{S}{2}=\sum_{i=1}^{n} Y_{i^{\prime}}$

Sujeito a:

$\sum_{j=1}^{n} x_{j} D_{i j}+Y_{i} \geq 0$

$\mathbf{f}^{\prime} \mathbf{x}=R_{0}$

$\mathbf{A x} \leq \mathbf{b}$

$\mathbf{x} \geq \mathbf{0}$ e $\mathbf{Y}_{\mathbf{i}} \geq 0$

onde $\mathbf{S}$ é soma dos desvios absolutos com relação às médias das receitas brutas; $\mathrm{D}_{\mathrm{ij}}$ é o desvio em relação à receita média da cultura $\mathbf{j}$ na ano i; $\mathbf{n}$ é o número de observações da 
amostra de receitas brutas e $\mathbf{R}_{\mathbf{0}}$ é o coeficiente de parametrização, crescendo a partir de zero até a solução máxima dada pelo primeiro modelo. Quando $\sum \mathrm{x}_{\mathrm{j}} \mathrm{D}_{\mathrm{ij}} \geq 0$, o Y correspondente assume valor zero, por causa das restrições dadas por (9) e (10). Y $\mathrm{i}_{\mathrm{i}}$ é, portanto, uma variável auxiliar que mede a soma dos desvios quando esta soma é negativa.

As receitas médias, $\overline{\mathrm{r}}_{\mathrm{j}}$, foram calculadas de acordo com:

$$
\sum_{i=1}^{n} \mathrm{P}_{\mathrm{ij}} v_{\mathrm{ij}} / \mathrm{n}=\overline{\mathrm{r}}_{\mathrm{j}}
$$

onde $\mathrm{P}_{\mathrm{ij}}$ é a produtividade da cultura $\mathbf{j}$ no ano $\mathbf{i}$. $\mathrm{O}$ valor de $v_{\mathrm{ij}}$ é o preço recebido pelos agricultores para a cultura $\mathbf{j}$ no ano $\mathbf{i}$. O desvio em relação à média foi calculado através de (14):

$\mathrm{D}_{\mathrm{ij}}=\left(\mathrm{P}_{\mathrm{ij}} v_{i j}-\mathrm{r}_{\mathrm{j}}\right)$

Com os resultados dos processos de minimização correspondentes ao parâmetro $\mathrm{R}_{0}$ ' , constrói-se a "fronteira eficiente", que expressa o risco envolvido para atingir determinado nível de receita bruta. Haverá, dessa forma, um conjunto de soluções eficientes, cabendo ao tomador de decisão a escolha daquela que seja compatível com sua preferência (maior ou menor aversão ao risco).

No modelo proposto, os desvios são tomados em relação a uma regressão linear simples, onde a variável dependente é a receita bruta e a variável explicativa é o tempo.

Minimizar:

$$
\frac{S_{r}}{2}=\sum_{i=1}^{n} Y_{i^{\prime}}
$$


Sujeito a:

$\sum_{j=1}^{n} x_{j} D_{r i j}+Y_{i} \geq 0$

$\mathbf{f}^{\prime} \mathbf{x}=R_{0}$

$\mathbf{A x} \leq \mathbf{b}$

$\mathbf{x} \geq \mathbf{0}$ e $\mathbf{Y}_{\mathbf{i}} \geq 0$

onde $S_{\mathrm{r}}$ passa a ser a soma dos desvios absolutos com relação às regressão lineares das receitas brutas; $\mathrm{D}_{\text {rij }}$, o desvio em relação à regressão linear da receita média da cultura $\mathbf{j}$ na ano $\mathbf{i}, \mathbf{n}$ é o número de observações da amostra de receitas brutas e $\mathbf{R}_{\mathbf{0}}$ é o coeficiente de parametrização, crescendo a partir de zero até a solução máxima dada pelo primeiro modelo. Quando $\sum \mathrm{x}_{\mathrm{j}} \mathrm{D}_{\mathrm{rij}} \geq 0$, o $\mathrm{Y}$ correspondente assume valor zero, por causa das restrições dadas por (9) e (10). $Y_{\mathrm{i}}$ é, portanto, uma variável auxiliar que mede a soma dos desvios quando esta soma é negativa.

O desvio absoluto da receita bruta em relação à regressão linear simples das receitas brutas ao longo do tempo foi calculado através de (20):

$D_{r}=P_{i j} v_{i j}-\left(\alpha+\beta X_{i j}\right)$

onde $\mathrm{P}_{\mathrm{ij}}$ é a produtividade da cultura $\mathbf{j}$ no ano $\mathbf{i}$. O valor de $v_{\mathrm{ij}}$ é o preço recebido pelos agricultores para a cultura $\mathbf{j}$ no ano $\mathbf{i}$, portanto, $\mathrm{P}_{\mathrm{ij}} v_{\mathrm{ij}}$ é igual à receita bruta da cultura $\mathbf{j}$ no ano i. O $\alpha$ é o coeficiente angular e $\beta$ é o coeficiente da variável independente. 
O modelo quadrático é construído com base na matriz de variância e covariância dos desvios da receita bruta em relação à regressão linear de cada cultura, conforme descrito em (20). A função objetivo tem o seguinte formato:

$\min : \Omega=X \sigma^{2} X$

onde $\mathrm{X}$ é o vetor das atividades possíveis e $\sigma^{2}$, a matriz de variância e covariância. As restrições são as mesmas do modelo linear. 


\section{RESULTADOS E DISCUSSÃO}

\subsection{Relações entre a receịta bruta das diversas culturas}

$\mathrm{O}$ trabalho de pesquisa procurou traçar perfis dos produtores e de propriedades agrícolas em duas regiões distintas do país. Para tanto, foram construídos dois modelos matemáticos, um linear e outro quadrático. As regiões escolhidas para análise foram Tangará da Serra, no Mato Grosso, e Carazinho, no Rio Grande do Sul. O produtor mato-grossense possui propriedade típica de 3.000 hectares e o do Rio Grande do Sul, propriedade de cerca de 200 hectares.

O perfil dos produtores do Centro-Oeste é marcado pelo espírito empreendedor de um empresário que aceitou a mudança para aquela região com a expectativa de crescimento da empresa. Neste processo, encontrou pela frente grandes áreas de cerrado por abrir e deficiências do sistema transporte, energia e comunicação. O nível cultural tem estreitas ligações com as origens européias de imigrantes italianos e alemães, mas com baixa escolaridade, sendo que a grande maioria não tem nível superior. As cidades são novas e a infra-estrutura está em fase inicial de desenvolvimento.

O gaúcho tem características distintas destas, com maior estabilidade financeira e infra-estrutura mais desenvolvida, mas, por outro lado, tem poucas chances de crescer em área de propriedade. O nível de educação é mais elevado, com a maior parte dos produtores contando com formação superior. Em comum, produtores gaúchos e matogrossenses têm a origem européia. $\mathrm{O}$ aspecto cultural é importante no momento da 
análise dos elementos ligados à taxa de aversão ao risco dos dois tipos de agricultores.

Os dados primários, fundamentais para a construção dos modelos, foram coletados em painéis realizados em ambas regiões. O modelo linear, MOTAD, foi definido por Markowitz (1952) que utilizou as variâncias como medida de risco. Este modelo foi modificado por Hazell (1971), que utilizou os desvios absolutos como medida de risco. O modelo da média-variância (E-V) retorna ao modelo original definido por Markowitz, e usa a matriz de variância e covariância como medida de risco. O MOTAD é um modelo amplamente utilizảdo devido à simplicidade de modelagem e à pouca exigibilidade em termos de recursos computacionais. O modelo E$\mathrm{V}$, por sua vez, tem algumas vantagens em termos de precisão dos resultados, já que não sofre processo de linearização.

$\mathrm{Na}$ fase inicial do trabalho foi necessária a construção de uma base de dados para a modelagem descrita. O painel possibilitou a obtenção de dados que espelham a realidade de uma safra e são vitais para a construção do modelo de maximização da renda. Para a construção dos cenários de risco, são utilizados dados históricos, uma vez que é através do comportamento da renda no longo prazo que são construídos os modelos.

\subsection{Mato Grosso}

Considerando as condições edafoclimáticas e de mercado, os produtores matogrossenses têm as seguintes atividades econômicas como opção: milho, soja, algodão, pecuária de corte e milho segunda safra (safrinha). Quando a referência é o sistema de produção mais comum, no MT encontra-se o solo sempre coberto por uma das atividades econômicas ou por cobertura vegetal - o milheto. 
Considera-se que o produtor rural é racional, indiferente ao risco e busca a combinação de atividades que ofereça maior retorno, levando-se em consideração, contudo, as restrições de área, caixa e crédito estabelecidas no modelo. Os retornos líquidos esperados para as atividades típicas da região estão apresentados na Tabela 21 .

Tabela 21. Retorno líquido das atividades no Mato Grosso, safra 1999/2000.

\begin{tabular}{ll}
\hline Atividade & Reais/ha \\
\hline Arroz & 29,35 \\
Milho safra & 30,04 \\
Milho safrinha & 36,33 \\
Soja & 95,68 \\
Algodão & 898,78 \\
Pecuária de corte & 18,35 \\
Cobertura (milheto) & $-43,20$ \\
\hline
\end{tabular}

Fonte: Resultados da pesquisa.

Esses retornos líquidos foram calculados com base nas informações das planilhas de custo de produção elaboradas a partir de painéis realizados na região de Tangará da Serra/MT, na safra 1999/2000. A receita foi obtida considerando-se os preços médios de acordo com os fluxos comerciais dos produtores e a produtividade. A cultura do algodão é a de maior rentabilidade, enquanto a de menor rentabilidade é a pecuária de corte. Portanto, é previsível que numa situação de indiferença a risco e recursos ilimitados os produtores aloquem toda a área para o algodão.

A ausência de limitação nos fatores de produção é totalmente irreal, por esse motivo são criadas equações que representam as restrições de solo e caixa do produtor. O primeiro conjunto de restrições do modelo reproduz os limites de área disponível, sendo que no MT, a propriedade típica é de 3 mil hectares. O segundo conjunto de restrições refere-se ao fluxo de caixa. O caixa inicial inclui $\mathrm{R} \$ 1$ milhão de capital próprio, mais o crédito oficial, que tem as seguintes limitações de volume para a safra 
1999/2000: $\mathrm{R} \$ 80$ mil para soja, $\mathrm{R} \$ 100$ mil para milho e $\mathrm{R} \$ 300$ mil para algodão. Estes valores são disponíveis aos agricultores a uma taxa de $8,75 \%$ ao ano mais os custos financeiros de $1,25 \%$ sobre o montante total. O capital total remanescente num período é utilizado no período subsequiente. Portanto, o modelo tem por finalidade a maximização da receita líquida, sujeito à restrição de área e de capital.

A construção da base de dados necessária para a modelagem é feita com painéis, conforme a descrição de Deblitz (1998). Os dados relativos ao fluxo de caixa da propriedade são de coleta própria e constituem a base para as restrições do modelo. As equações de caixa têm por finalidade reproduzir os entraves típicos de uma propriedade agrícola. Os momentos de desembolso geralmente não coincidem com os de entrada das receitas e, desta forma, a implementação de algumas atividades econômicas é inviabilizada. Os resultados do fluxo de caixa da propriedade típica do Mato Grosso (região Tangará da Serra) estão na Tabela 22.

Tabela 22. Fluxo de caixa da propriedade típica do Mato Grosso, 1999/00.

\begin{tabular}{|c|c|c|c|c|c|c|c|}
\hline & Arroz & $\begin{array}{l}\text { Milho } \\
\text { Safra }\end{array}$ & $\begin{array}{l}\text { Milho } \\
\text { Safrinha }\end{array}$ & $\begin{array}{l}\text { Soja } \\
\text { Convenc. }\end{array}$ & $\begin{array}{l}\text { Soja } \\
\text { Direto }\end{array}$ & $\begin{array}{l}\text { Algodão } \\
\text { Semidir. }\end{array}$ & $\begin{array}{l}\text { Boi } \\
\text { Brizantha }\end{array}$ \\
\hline $\begin{array}{l}\text { Caixa I } \\
\text { (jul-set) }\end{array}$ & 350,50 & 355,93 & 14,09 & 9,07 & 17,60 & 1505,60 & 84,48 \\
\hline $\begin{array}{l}\text { Caixa II } \\
\text { (out-dez) }\end{array}$ & 158,24 & 258,90 & 0,00 & 95,92 & 95,34 & 96,20 & 98,21 \\
\hline $\begin{array}{l}\text { Caixa III } \\
\text { (jan-mar) }\end{array}$ & 55,36 & $-368,36$ & 135,37 & 403,17 & 43,42 & 281,49 & $-55,65$ \\
\hline $\begin{array}{l}\text { Caixa IV } \\
\text { (abr-jun) }\end{array}$ & 0,00 & 0,00 & 107,76 & $-275,06$ & 118,06 & 115,60 & $-59,05$ \\
\hline $\begin{array}{l}\text { Caixa V } \\
\text { (próximos) }\end{array}$ & $-593,45$ & $-276,50$ & $-293,55$ & $-308,39$ & $-370,10$ & $-2897,68$ & $-86,35$ \\
\hline
\end{tabular}

Fonte: Resultados da pesquisa. 
A atividade que possui o fluxo de caixa mais estável, justamente por ter um ritmo comercial mais intenso, é a pecuária de corte. Para as demais, o fluxo está relacionados aos períodos de plantio e colheita. Neste caso, o custeio das atividades exige desembolsos mais pesados no segundo semestre, enquanto que as receitas maiores estão no inicio do ano.

Os resultados do modelo linear de maximização da receita para o estado do Mato Grosso são apresentados na Tabela 23.

Tabela 23. Resultados do modelo de maximização da renda no Mato Grosso.

\begin{tabular}{lll}
\hline Atividade & Área (ha) & Participação \\
\hline Milho safrinha & 0 & $0,00 \%$ \\
Arroz & 0 & $0,00 \%$ \\
Milho safra & 0 & $0,00 \%$ \\
Soja & 0 & $0,00 \%$ \\
Algodão & 400,85 & $13,36 \%$ \\
Boi & 2599,15 & $86,64 \%$ \\
\hline
\end{tabular}

Fonte: Resultados da pesquisa.

O produtor rural, neste caso, estaria agindo de maneira indiferente aos riscos das atividades. Os resultados apontam que o capital próprio é completado com recursos proveniente de uma operação de crédito rural em valor suficiente para o plantio de 64,41 hectares de algodão. A pecuária, alternativa de baixo custo e rentabilidade, utiliza a área remanescente da propriedade, isto ocorre pelo fato do modelo estar definido de modo a impor que a terra nunca fique descoberta. Dessa forma, se o produtor não tivesse atividade pecuária, além de não ter a rentabilidade dessa atividade, precisaria investir $R$ \$ 43,20 por hectare no plantio de milheto para cobertura. 
Os resultados do modelo de maximização não refletem a realidade, pois os produtores rurais dificilmente estão totalmente indiferentes ao risco. Isto é comprovado pelos resultados dos painéis, descritos no capítulo que trata das fontes de dados.

O produtor procura alternativas que ofereçam resultados favoráveis, mas, ao mesmo tempo, está preocupado com os fatos inesperados que possam afetar a renda, podendo estes serem de ordem climática e/ou fitossanitária que influenciam na produtividade e nas oscilações de preços.

\subsubsection{Desvios absolutos da receita bruta: medida linear de risco}

A renda bruta dos produtores depende dos preços de venda dos produtos e das produtividades das atividades agrícolas. As variações inesperadas da receita bruta são utilizadas como medida de risco dos produtores. O comportamento dos preços está atrelado a fatores de mercado e a produtividade está condicionada a fatores climáticos e biológicos, todos eles imprevisíveis em algum grau. Na Tabela 24 estão os dados de produtividade das principais culturas ao longo das últimas 10 safras. 
Tabela 24. Produtividade média por hectare - Mato Grosso.

\begin{tabular}{|c|c|c|c|c|c|c|}
\hline Safra & $\begin{array}{l}\text { Arroz } \\
\text { sc/ha }\end{array}$ & $\begin{array}{l}\text { Soja } \\
\text { sc/ha }\end{array}$ & $\begin{array}{l}\text { Milho } \\
\text { sc/ha }\end{array}$ & $\begin{array}{l}\text { Milho safrinha } \\
\text { sc/há }\end{array}$ & $\begin{array}{l}\text { Algodão } \\
@ / h a\end{array}$ & $\begin{array}{l}\text { Boi Gordo } \\
\text { cabeças }\end{array}$ \\
\hline $89 / 90$ & 20 & 33,43 & 38,83 & 31,54 & 1091,47 & 9,86 \\
\hline 90/91 & 26 & 42,18 & 40,17 & 28,33 & 898,12 & 9,86 \\
\hline $91 / 92$ & 25 & 41,77 & 46,50 & 25,00 & 1055,47 & 9,86 \\
\hline $92 / 93$ & 20 & 40,90 & 50,00 & 22,34 & 1030,36 & 9,86 \\
\hline $93 / 94$ & 28 & 43,83 & 51,67 & 30,00 & 1163,45 & 9,86 \\
\hline $94 / 95$ & 30 & 39,40 & 55,00 & 35,67 & 1054,64 & 9,86 \\
\hline $95 / 96$ & 28 & 41,00 & 55,83 & 30,84 & 1118,25 & 9,86 \\
\hline $96 / 97$ & 33 & 45,50 & 61,67 & 35,00 & 1506,62 & 9,86 \\
\hline $97 / 98$ & 35 & 45,03 & 57,67 & 35,83 & 2424,83 & 9,86 \\
\hline $98 / 99$ & 39 & 46,67 & 61,67 & 25,00 & 2460,819 & 9,86 \\
\hline
\end{tabular}

Fonte: Conab.

A produtividade das culturas agrícolas cresceu expressivamente no período compreendido entre as safras 89/90 - 98/99, com exceção da pecuária de corte, cuja produtividade foi considerada constante, uma vez que o sistema de produção utilizado é de baixa intensificação e pouco sensível a fatores climáticos. Já o algodão e a soja apresentam grandes ganhos de produtividade ao longo dos anos-safra considerados. Isto pode ser atribuído à adoção de novas tecnologias.

O valor médio de produção foi estimado considerando o preço efetivo de comercialização da safra. Esse valor constitui-se na média ponderada dos preços obtidos na venda dos produtos, cujos pesos de ponderação são os volumes comercializados durante o ano-safra, aos diferentes preços, conforme indicava o fluxo comercial levantado no painel. Isto permite incorporar os efeitos da sazonalidade dos preços sobre a receita bruta dos produtores. O fluxo comercial está apresentado na Tabela 25. 
Tabela 25. Fluxo comercial da produção de uma propriedade típica do Mato Grosso.

\begin{tabular}{lllll} 
& Algodão & Soja & Milho & Boi \\
\hline Jan & $0 \%$ & $0 \%$ & $0 \%$ & $10,34 \%$ \\
Fev & $0 \%$ & $13 \%$ & $0 \%$ & $10,34 \%$ \\
Mar & $0 \%$ & $29 \%$ & $0 \%$ & $10,34 \%$ \\
Abr & $0 \%$ & $6 \%$ & $0 \%$ & $10,34 \%$ \\
Mai & $0 \%$ & $5 \%$ & $0 \%$ & $10,34 \%$ \\
Jun & $20 \%$ & $9 \%$ & $0 \%$ & $3,45 \%$ \\
Jul & $30 \%$ & $10 \%$ & $60 \%$ & $3,45 \%$ \\
Ago & $10 \%$ & $8 \%$ & $20 \%$ & $0,00 \%$ \\
Set & $20 \%$ & $20 \%$ & $20 \%$ & $3,45 \%$ \\
Out & $20 \%$ & $2 \%$ & $0 \%$ & $10,34 \%$ \\
Nov & $0 \%$ & $0 \%$ & $0 \%$ & $13,79 \%$ \\
Dez & $0 \%$ & $0 \%$ & $0 \%$ & $13,79 \%$ \\
\hline
\end{tabular}

Fonte: Resultado da pesquisa.

Nos painéis foram apurados os dados do fluxo da comercialização dos seguintes produtos: algodão, soja, milho e boi. O arroz foi desconsiderado, pois a intervenção do governo é grande e o produto pode ser entregue ao governo em qualquer época do ano, a preços fixos.

Os dados levantados mostram que os produtores concentram as vendas dos produtos de culturas anuais nos meses de safra. A soja, colhida entre fevereiro e maio, tem aproximadamente $50 \%$ do seu volume comercializado nos primeiros meses da colheita. No início do segundo semestre, o produtor tem receita proveniente do algodão, colhido entre maio e agosto, mas grande parte da comercialização desse produto ocorre nos primeiros meses da safra.

De posse dos dados de produtividade e preços médios dos produtos, é possível calcular a receita bruta das últimas 10 safras. Esses dados estão apresentados na Tabela 
26 e mostram que a receita bruta do algodão é a que mais cresceu no período, mas é também a que apresenta as maiores variações.

Tabela 26. Receita bruta, por safra e por produto, no Mato Grosso ( $\mathrm{R} \$ / \mathrm{ha})$.

\begin{tabular}{cllllll}
\hline Safra & Arroz & Algodão & Soja & Milho & \multicolumn{2}{c}{ Milho safrinha Boi } \\
\hline $89 / 90$ & 450 & $1.064,32$ & 497,89 & 569,85 & 462,81 & 474,29 \\
$90 / 91$ & 739 & 825,54 & 814,71 & 528,24 & 372,62 & 458,91 \\
$91 / 92$ & 517 & 873,78 & 916,87 & 562,26 & 302,29 & 458,27 \\
$92 / 93$ & 359 & 906,16 & 659,62 & 635,14 & 283,79 & 452,26 \\
$93 / 94$ & 526 & $1.084,07$ & 731,04 & 550,11 & 319,41 & 455,64 \\
$94 / 95$ & 409 & 755,50 & 446,32 & 433,70 & 281,25 & 341,10 \\
$95 / 96$ & 397 & $1.049,92$ & 577,47 & 507,69 & 280,38 & 302,02 \\
$96 / 97$ & 476 & $1.766,88$ & 791,30 & 482,69 & 273,94 & 311,58 \\
$97 / 98$ & 673 & $2.395,58$ & 596,05 & 477,80 & 296,87 & 350,60 \\
$98 / 99$ & 640 & $2.579,21$ & 722,70 & 481,97 & 195,40 & 354,14 \\
\hline
\end{tabular}

Fonte: Resultados da pesquisa.

Com base nos dados de receita bruta é feita uma regressão linear simples dessa variável (tida como dependente) contra uma variável tendência (explicativa). A reta de regressão originada expressa a expectativa de receita bruta dos agricultores para 0 período seguinte, ou seja, considera-se que o produtor, no processo de tomada de decisão, não observa apenas o nível de preço mas também a tendência desse preço. Os desvios, obtidos da subtração dos valores estimados dos observados, expressam a diferença entre a expectativa do produtor e a receita bruta verificada. Essas diferenças constituem-se nos riscos das atividades, sendo que quanto maior o desvio maior o risco associado a elas. Os desvios calculados para as atividades do Mato Grosso estão apresentados na Tabela 27. 
Tabela 27. Desvios absolutos da receita bruta - Mato Grosso.

\begin{tabular}{lllllll}
\hline Safra & Arroz & Milho & Milho safrinha & Soja & Algodão & Boi \\
\hline $89 / 90$ & $-131,34$ & $-21,81$ & 70,65 & $-200,11$ & $1.021,70$ & $-7,38$ \\
$90 / 91$ & 791,44 & $-94,75$ & $-0,59$ & 157,06 & 220,89 & $-9,91$ \\
$91 / 92$ & 46,21 & 20,93 & 16,98 & 272,23 & $-26,98$ & 15,79 \\
$92 / 93$ & $-490,11$ & 233,46 & $-0,50$ & $-17,79$ & $-305,42$ & 28,06 \\
$93 / 94$ & 34,44 & 52,29 & 90,30 & 62,73 & $-303,52$ & 48,66 \\
$94 / 95$ & $-368,05$ & $-207,12$ & 33,48 & $-258,26$ & $-1.277,28$ & $-30,84$ \\
$95 / 96$ & $-427,79$ & 8,19 & 51,29 & $-110,40$ & $-1.050,94$ & $-63,95$ \\
$96 / 97$ & $-190,49$ & $-23,29$ & 57,93 & 130,67 & $-10,64$ & $-29,68$ \\
$97 / 98$ & 431,99 & $-4,65$ & 123,35 & $-89,45$ & 859,63 & $-1,98$ \\
$98 / 99$ & 303,69 & 36,58 & $-60,16$ & 53,33 & 872,55 & 51,22 \\
\hline
\end{tabular}

Fonte: Resultados da pesquisa.

Os desvios negativos representam as frustrações em relação ao esperado. Dentre as atividades mais comuns na região, o algodão é o produto que apresenta os maiores desvios, ou seja, é o produto que tem o maior risco e a pecuária de corte é a atividade econômica de menor risco.

A próxima etapa do estudo consiste na inclusão do risco ao modelo, considerando os desvios absolutos da receita bruta como medida de risco.

\subsubsection{Modelos com a inclusão de riscos}

Para a implementação dos modelos de risco, foram calculados os desvios absolutos das receita brutas das atividades econômicas da propriedade ao longo dos últimos 10 anos. Em alguns casos, especialmente do algodão, a receita bruta foi positiva, pois os ganhos de produtividade compensaram os menores preços das commodities 
agrícolas na região (MT). No entanto, para outros produtos, o sentido é inverso, caso específico do milho. Na pecuária de corte, foram considerados apenas os riscos de preços, uma vez que o sistema de produção analisado é de baixa produtividade e pouco afetado por fatores climáticos.

O novo modelo linear passa a ter como objetivo a minimização dos riscos para um dado retorno. Este modelo foi descrito por Hazell (1971), que utiliza os desvios em relação à receita média - MOTAD como medida de risco. No presente trabalho, diferentemente do de Hazell, os desvios utilizados são calculados em relação a uma regressão linear da receita bruta contra o tempo, conforme já discutido.

Os resultados modificam-se de forma significativa, aproximando-se da realidade verificada no trabalho de campo. Os resultados incorporam mais atividades, mostrando que a minimização dos riscos envolve um processo de diversificação. A soja e o milho safrinha são incluídos entre as atividades econômicas da propriedade agrícola para todos os níveis de receita líquida definidos.

No ponto de mínimo risco associado ao de máximo rendimento ( $\mathrm{R} \$ 380$ mil - um dado exógeno fornecido com base no modelo de maximização da receita líquida), incluem-se as seguintes atividades: milho safrinha $(2,24 \%$ da área total), algodão $(12,88 \%)$, soja $(2,24 \%)$ e pecuária $(84,87 \%)$. Esse novo conjunto engloba, então, duas atividades não consideradas anteriormente no modelo de maximização da receita líquida sem riscos. Os resultados estão apresentados na Tabela 28 e mostram as combinações de atividades possíveis do modelo à media que a receita líquida esperada é reduzida. 
Tabela 28. Resultados do MOTAD aplicado no Mato Grosso.

\begin{tabular}{|c|c|c|c|c|}
\hline $\begin{array}{l}\text { Retornos esperados } \\
\text { (R\$/ano) } \\
\end{array}$ & $\begin{array}{l}\text { Desvios } \\
\text { absolutos }\end{array}$ & Atividade & $\begin{array}{l}\text { Âreas } \\
\text { (ha) }\end{array}$ & $\begin{array}{l}\text { Proporção de } \\
\text { cada atividade }\end{array}$ \\
\hline \multirow[t]{6}{*}{50000} & \multirow[t]{6}{*}{376282,1} & Milho safrinha & 620,62 & $20,69 \%$ \\
\hline & & Arroz & 0 & $0,00 \%$ \\
\hline & & Milho & 0 & $0,00 \%$ \\
\hline & & Soja & 128,23 & $4,27 \%$ \\
\hline & & Algodão & 48,82 & $1,63 \%$ \\
\hline & & Boi & 2330,55 & $77,69 \%$ \\
\hline \multirow[t]{6}{*}{100000} & \multirow[t]{6}{*}{437208} & Milho safrinha & 399,63 & $13,32 \%$ \\
\hline & & Arroz & 0 & $0,00 \%$ \\
\hline & & Milho & 0 & $0,00 \%$ \\
\hline & & Soja & 112,99 & $3,77 \%$ \\
\hline & & Algodão & 82,39 & $2,75 \%$ \\
\hline & & Boi & 2517,97 & $83,93 \%$ \\
\hline \multirow[t]{6}{*}{150000} & \multirow[t]{6}{*}{498133,9} & Milho safrinha & 178,63 & $5,95 \%$ \\
\hline & & Arroz & 0 & $0,00 \%$ \\
\hline & & Milho & 0 & $0,00 \%$ \\
\hline & & Soja & 97,75 & $3,26 \%$ \\
\hline & & Algodão & 115,96 & $3,87 \%$ \\
\hline & & Boi & 2705,39 & $90,18 \%$ \\
\hline \multirow[t]{6}{*}{200000} & \multirow[t]{6}{*}{559459} & Milho safrinha & 490,88 & $16,36 \%$ \\
\hline & & Arroz & 0 & $0,00 \%$ \\
\hline & & Milho & 0 & $0,00 \%$ \\
\hline & & Soja & 490 & $16,33 \%$ \\
\hline & & Algodão & 131,8 & $4,39 \%$ \\
\hline & & Boi & 2377,84 & $79,26 \%$ \\
\hline \multirow[t]{2}{*}{250000} & \multirow[t]{2}{*}{624423,4} & Milho safrinha & 511,37 & $17,05 \%$ \\
\hline & & Arroz & 0 & $0,00 \%$ \\
\hline
\end{tabular}


Tabela 28. Resultados do MOTAD aplicado no Mato Grosso.

\begin{tabular}{|c|c|c|c|c|}
\hline $\begin{array}{l}\text { Retornos esperados } \\
\text { (R\$/ano) }\end{array}$ & $\begin{array}{l}\begin{array}{l}\text { Desvios } \\
\text { absolutos }\end{array} \\
\end{array}$ & Atividade & $\begin{array}{l}\text { Áreas } \\
\text { (ha) }\end{array}$ & $\begin{array}{l}\text { Proporção de } \\
\text { cada atividade }\end{array}$ \\
\hline \multirow{10}{*}{300000} & \multirow{10}{*}{690244,1} & Milho & 0 & $0,00 \%$ \\
\hline & & Soja & 511,37 & $17,05 \%$ \\
\hline & & Algodão & 189,8 & $6,33 \%$ \\
\hline & & Boi & 2298,81 & $76,63 \%$ \\
\hline & & Milho safrinha & 371,44 & $12,38 \%$ \\
\hline & & Arroz & 0 & $0,00 \%$ \\
\hline & & Milho & 0 & $0,00 \%$ \\
\hline & & Soja & 511,37 & $17,05 \%$ \\
\hline & & Algodão & 189,8 & $6,33 \%$ \\
\hline & & Boi & 2298,81 & $76,63 \%$ \\
\hline \multirow[t]{6}{*}{330000} & \multirow[t]{6}{*}{729736,6} & Milho safrinha & 227,48 & $7,58 \%$ \\
\hline & & Arroz & 0 & $0,00 \%$ \\
\hline & & Milho & 0 & $0,00 \%$ \\
\hline & & Soja & 287,48 & $9,58 \%$ \\
\hline & & Algodão & 304 & $10,13 \%$ \\
\hline & & Boi & 2408,3 & $80,28 \%$ \\
\hline \multirow[t]{6}{*}{380000} & \multirow[t]{6}{*}{800411,5} & Milho safrinha & 67,07 & $2,24 \%$ \\
\hline & & Arroz & 0 & $0,00 \%$ \\
\hline & & Milho & 0 & $0,00 \%$ \\
\hline & & Soja & 67,07 & $2,24 \%$ \\
\hline & & Algodão & 386,54 & $12,88 \%$ \\
\hline & & Boi & 2546 & $84,87 \%$ \\
\hline
\end{tabular}

Fonte: Resultados da pesquisa.

Os resultados do modelo que incorpora o risco mostram que os produtores do Mato Grosso devem diversificar a produção para qualquer nível de retorno esperado. Os 
produtos que compõem o grupo de atividades econômicas são os mesmos para qualquer nível de retorno. O algodão é a atividade que sede espaço para outras, particularmente para a soja, nos níveis intermediários de retorno. Quando a receita líquida esperada é menor, as atividades agrícolas em conjunto perdem espaço para a atividade pecuária.

A diversificação de atividades em todas as faixas de retorno comprova a tese de que os produtores estão corretos na diversificação das atividades quando buscam a minimização dos riscos. Os resultados do MOTAD ainda estão distantes da composição de atividades verificada no campo. Isto pode representar duas indicações: os produtores não estão num ponto de máxima eficiência que os seus recursos possibilitam, ou o modelo apresenta deficiências de aproximação.

\subsection{Rio Grande do Sul}

Os produtores típicos da região de Carazinho/RS produzem milho, soja, trigo e pecuária de corte. A técnica de plantio direto é utilizada na região, propiciando a cobertura do solo. Esta cobertura pode ser natural (azevém) ou cultivada com milheto.

Na primeira etapa dessa análise regional feita para o Rio Grande do Sul utilizouse, assim como no caso do Mato Grosso, o modelo de maximização da receita líquida do produtor, considerando que ele seja racional e indiferente ao risco. Esses produtores dispõem dos seguintes retomos líquidos para as diversas atividades potenciais: 
Tabela 29. Retorno por atividade.

\begin{tabular}{ll}
\hline Atividades & Reais/ha \\
\hline Milho & 735,75 \\
Soja & 219,40 \\
Trigo & 150,76 \\
Pecuária de corte & 49,92 \\
Cobertura & $-42,30$ \\
\hline
\end{tabular}

Fonte: Resultados da pesquisa.

Os retornos líquidos referem-se à safra 2000/2001, sendo que os do milho foram muito superiores aos da cultura da soja. Estas duas atividades disputam a área agricultável no verão, enquanto que o trigo e a pecuária de corte disputam a área no inverno.

No modelo de maximização da receita líquida, existem fatores limitantes relacionados à disponibilidade de solo e de capital. A área agricultável disponível na propriedade típica da região é de aproximadamente 200 hectares. O fluxo de caixa das atividades está apresentado na Tabela 30, elaborada a partir dos dados coletados no painel feito na região de Carazinho/RS.

Tabela 30. Fluxo de caixa de um hectare numa propriedade em Carazinho/RS.

\begin{tabular}{lllll}
\hline & Milho & Soja & Trigo & Pecuária de corte \\
\hline Caixa I (jul-set) & $-149,65$ & $-39,47$ & $-6,14$ & $-12,73$ \\
Caixa II (out-dez) & $-8,00$ & $-128,33$ & $-279,51$ & $-7,67$ \\
Caixa III (jan-mar) & $-85,34$ & $-2,55$ & 0,00 & 0,00 \\
Caixa IV (abr-jun) & 154,20 & $-129,61$ & 237,55 & $-262,48$ \\
Caixa V (próximos) & 826,54 & 519,36 & 198,85 & 332,80 \\
\hline
\end{tabular}

Fonte: Resultados da pesquisa. 
Os fluxos de caixa das atividades mostram que a demanda por capital inicial para a produção do milho é maior que a da soja. Isto se explica pelo ciclo mais curto do milho e pelo fato dos tratos culturais da soja concentrarem-se principalmente nas etapas finais da produção. Na pecuária, os desembolsos ocorrem principalmente entre abril e junho, quando os animais para engorda são adquiridos. A manutenção do rebanho tem baixo custo comparativamente às outras atividades. Na modelagem matemática, o fluxo de caixa é uma restrição importante, pois a combinação de atividades deve ser definida considerando a capacidade de desembolso da propriedade.

O modelo de maximização da receita líquida de uma propriedade gaúcha, com as restrições de solo e caixa, tem os resultados apresentados na Tabela 31.

Tabela 31. Resultados do modelo de maximização.

\begin{tabular}{ll}
\hline Atividades & Área (hectares) \\
\hline Milho & 188,89 \\
Trigo & 190,00 \\
\hline
\end{tabular}

Fonte: Resultados da pesquisa.

No processo de maximização da receita líquida da propriedade, todos os recursos são alocados para o milho e trigo. O produtor toma crédito oficial para plantar milho na sua totalidade e utiliza o capital próprio de $\mathrm{R} \$ 80$ mil na cultura do trigo. Neste modelo, fica evidente que, se os produtores fossem indiferentes ao risco, teriam apenas duas atividades na propriedade. 


\subsubsection{Desvios absolutos da receita bruta: medida linear de riscos}

A receita bruta liquida dos produtores gaúchos é calculada da mesma forma que a dos mato-grossenses. A produtividade média é multiplicada pelo valor de venda dos produtos, calculado como uma média ponderada dos preços obtidos ao longo do anosafra, tendo como pesos de ponderação os volumes comercializados definidos no painel. Na Tabela 32 são apresentados esses dados.

Tabela 32. Fluxo comercial de uma propriedade em Carazinho/RS.

\begin{tabular}{lllll}
\hline Mês & Milho & Soja & Trigo & Pecuária de corte \\
\hline Jan & $0 \%$ & $0 \%$ & $30 \%$ & $0 \%$ \\
Fev & $20 \%$ & $0 \%$ & $0 \%$ & $0 \%$ \\
Mar & $0 \%$ & $0 \%$ & $30 \%$ & $0 \%$ \\
Abr & $0 \%$ & $30 \%$ & $0 \%$ & $0 \%$ \\
Mai & $20 \%$ & $10 \%$ & $0 \%$ & $0 \%$ \\
Jun & $0 \%$ & $20 \%$ & $0 \%$ & $0 \%$ \\
Jul & $20 \%$ & $0 \%$ & $0 \%$ & $0 \%$ \\
Ago & $10 \%$ & $0 \%$ & $0 \%$ & $0 \%$ \\
Set & $0 \%$ & $20 \%$ & $0 \%$ & $25 \%$ \\
Out & $10 \%$ & $0 \%$ & $0 \%$ & $65 \%$ \\
Nov & $20 \%$ & $20 \%$ & $0 \%$ & $10 \%$ \\
Dez & $0 \%$ & $0 \%$ & $40 \%$ & $0 \%$ \\
\hline
\end{tabular}

Fonte: Resultados da pesquisa.

O processo de comercialização da safra no Rio Grande do Sul é semelhante ao do Mato Grosso. Na safra, uma parcela considerável da produção é vendida, exceto no caso do milho, que tem a comercialização distribuída ao longo do ano. Os produtores têm condições de financiamento oficiais para o milho que não encontram para a soja. $\mathrm{O}$ milho tem linhas de EGF, contratos de opções de venda e Prêmios de Escoamento do Produto que modificam a dinâmica comercial. Já a soja não tem recebido suporte 
governamental por meio de políticas comerciais e a alternativa para o produtor levantar recursos para esta cultura é a venda antecipada do produto. As políticas e as formas diferenciadas de comercialização entram indiretamente no modelo, através das restrições de fluxo de caixa e dos preços médios recebidos.

A produtividade considerada na análise refere-se à média obtida em duas propriedades da região de Carazinho/RS. Os preços médios anuais foram calculados com base nas séries de preços da Emater/RS.

Seguindo os procedimentos adotados para o Mato Grosso, os desvios absolutos das receitas brutas utilizados no processo de minimização foram calculados em relação à tendência e não em relação à média como fez Hazell (1971) .

Tabela 33. Desvios de receita bruta no Rio Grande do Sul.

\begin{tabular}{cllll}
\hline Safra & Milho & Soja & Trigo & Pecuária de corte \\
\hline $90 / 91$ & $-380,28$ & 143,33 & $-262,52$ & $-32,26$ \\
$91 / 92$ & 260,67 & 96,63 & $-57,12$ & 142,20 \\
$92 / 93$ & 354,10 & 37,04 & $-302,88$ & 80,22 \\
$93 / 94$ & 196,60 & $-143,28$ & $-76,99$ & $-6,83$ \\
$94 / 95$ & $-282,72$ & $-74,91$ & $-0,56$ & $-499,20$ \\
$95 / 96$ & $-445,59$ & 146,00 & 22,36 & 129,77 \\
$96 / 97$ & 102,88 & $-122,81$ & $-154,15$ & 61,91 \\
$97 / 98$ & 229,52 & $-102,61$ & $-59,73$ & 226,20 \\
$98 / 99$ & 108,22 & 70,18 & 290,83 & $-29,97$ \\
$99 / 00$ & $-143,15$ & 181,65 & 224,30 & $-72,33$ \\
\hline
\end{tabular}

Fonte: Resultados da pesquisa.

A série dos desvios da receita bruta das diferentes atividades econômicas potenciais para do Rio Grande do Sul é apresentada na Tabela 33, onde verifica-se que os maiores desvios negativos são encontrados no caso do milho e na pecuária de corte. É interessante recordar que a pecuária gaúcha tem padrão tecnológico diferente da mato- 
grossense. A pecuária na região Sul é feita com base em culturas de inverno, que estão mais sujeitas aos efeitos das variações climáticas. Isso foi incorporado ao modelo no momento em que foram consideradas as variações de produtividade ao longo do tempo.

No modelo construído com o objetivo de minimizar os desvios da receita bruta para determinados níveis de retorno, obtiveram-se os resultados apresentados na tabela abaixo.

Tabela 34. Resultados do MOTAD aplicado no Rio Grande do Sul.

\begin{tabular}{|c|c|c|c|c|}
\hline $\begin{array}{l}\text { Retornos esperados } \\
\mathrm{R} \$ \text { /ano }\end{array}$ & $\begin{array}{l}\text { Desvios } \\
\text { absolutos } \\
\end{array}$ & Atividades & $\begin{array}{l}\text { Área } \\
\text { (ha) }\end{array}$ & $\begin{array}{l}\text { Proporção de } \\
\text { cada atividade }\end{array}$ \\
\hline \multirow[t]{7}{*}{$25.000,00$} & \multirow[t]{7}{*}{32918} & Soja & 79,4 & $41,79 \%$ \\
\hline & & Milho & 29,95 & $15,76 \%$ \\
\hline & & Trigo & 0 & $0,00 \%$ \\
\hline & & Boi & 29,94 & $15,76 \%$ \\
\hline & & Cob12 & 160,05 & - \\
\hline & & Cob56 & 50,69 & - \\
\hline & & Cob6 & 160,05 & - \\
\hline \multirow[t]{7}{*}{$30.000,00$} & \multirow[t]{7}{*}{36234,83} & Soja & 87,4 & $46,00 \%$ \\
\hline & & Milho & 32,97 & $17,35 \%$ \\
\hline & & Trigo & 0 & $0,00 \%$ \\
\hline & & Boi & 32,97 & $17,35 \%$ \\
\hline & & Cob12 & 157,03 & - \\
\hline & & Cob56 & 36,65 & - \\
\hline & & Cob6 & 157,03 & - \\
\hline \multirow[t]{6}{*}{$50.000,00$} & \multirow[t]{6}{*}{49894,33} & Soja & 130,89 & $68,89 \%$ \\
\hline & & Milho & 49,28 & $25,94 \%$ \\
\hline & & Trigo & 0 & $0,00 \%$ \\
\hline & & Boi & 9,82 & $5,17 \%$ \\
\hline & & Cob12 & 188,177 & - \\
\hline & & Cob6 & 188,177 & - \\
\hline
\end{tabular}


Tabela 34. Resultados do MOTAD aplicado no Rio Grande do Sul.

\begin{tabular}{|c|c|c|c|c|}
\hline $\begin{array}{l}\text { Retornos esperados } \\
\mathrm{R} \$ \text { /ano }\end{array}$ & $\begin{array}{l}\text { Desvios } \\
\text { absolutos }\end{array}$ & Atividades & $\begin{array}{l}\text { Área } \\
\text { (ha) }\end{array}$ & $\begin{array}{l}\text { Proporção de } \\
\text { cada atividade }\end{array}$ \\
\hline \multirow[t]{6}{*}{$80.000,00$} & \multirow[t]{6}{*}{95440,34} & Soja & 97,79 & $51,47 \%$ \\
\hline & & Milho & 92,2 & $48,53 \%$ \\
\hline & & Trigo & 29,23 & $15,38 \%$ \\
\hline & & Boi & 0 & $0,00 \%$ \\
\hline & & Cob12 & 160,76 & - \\
\hline & & Cob6 & 160,76 & - \\
\hline \multirow[t]{6}{*}{$100.000,00$} & \multirow[t]{6}{*}{133113,4} & Soja & 79,31 & $41,74 \%$ \\
\hline & & Milho & 110,68 & $58,25 \%$ \\
\hline & & Trigo & 73,17 & $38,51 \%$ \\
\hline & & Boi & 0 & $0,00 \%$ \\
\hline & & Cob12 & 116,82 & - \\
\hline & & Cob6 & 116,82 & - \\
\hline \multirow[t]{6}{*}{$120.000,00$} & \multirow[t]{6}{*}{170786,4} & Soja & 60,83 & $32,02 \%$ \\
\hline & & Milho & 129,12 & $67,96 \%$ \\
\hline & & Trigo & 117,11 & $61,64 \%$ \\
\hline & & Boi & 0 & $0,00 \%$ \\
\hline & & Cob12 & 72,88 & - \\
\hline & & Cob6 & 72,88 & - \\
\hline \multirow[t]{6}{*}{$150.000,00$} & \multirow[t]{6}{*}{228301,7} & Soja & 32,62 & $17,17 \%$ \\
\hline & & Milho & 157,38 & $82,83 \%$ \\
\hline & & Trigo & 184,19 & $96,94 \%$ \\
\hline & & Boi & 0 & $0,00 \%$ \\
\hline & & Cob12 & 5,8 & - \\
\hline & & Cob6 & 5,8 & - \\
\hline \multirow[t]{2}{*}{$166.000,00$} & \multirow[t]{2}{*}{264656,3} & Soja & 0,773 & $0,41 \%$ \\
\hline & & Milho & 188,36 & $99,14 \%$ \\
\hline
\end{tabular}


Tabela 34. Resultados do MOTAD aplicado no Rio Grande do Sul.

\begin{tabular}{lllll}
\hline $\begin{array}{l}\text { Retornos esperados } \\
\mathrm{R} \$ \text { /ano }\end{array}$ & $\begin{array}{l}\text { Desvios } \\
\text { absolutos }\end{array}$ & Atividades & $\begin{array}{l}\text { Área } \\
\text { (ha) }\end{array}$ & $\begin{array}{l}\text { Proporção de } \\
\text { cada atividade }\end{array}$ \\
\hline & & Trigo & 190 & $100,00 \%$ \\
& Boi & 0 & $0,00 \%$ \\
& & Cob56 & 0,8697 & - \\
\hline
\end{tabular}

Fonte: Resultados da pesquisa.

O ponto de receita líquida máxima foi obtido no modelo de maximização da renda, que apontava para a alocação de toda a área para o milho no verão e trigo no inverno. Os resultados do modelo de risco incluem a soja no conjunto de atividades da propriedade. Nos pontos de maior receita líquida esperada, a participação da soja é pequena, menos de $1 \%$ para uma receita bruta de $\mathrm{R} \$ 166$ mil; já para a receita liquida esperada menor que $\mathrm{R} \$ 100$ mil, a participação da soja supera a do milho.

Os produtores da região têm adotado uma divisão entre as áreas de soja e milho, sendo que a alocação de área entre esses dois produtos é condicionada aos retornos obtidos na safra anterior. No modelo, os pontos mais próximos da combinação verificada na região estão entre a receita líquida de $R \$ 80$ mil e $R \$ 100$ mil. Neste intervalo, os produtores possuem cerca de $50 \%$ da área com cada um dos produtos.

\subsubsection{Limitações do modelo}

O MOTAD, segundo Peres (1976), oferece um conjunto de resultados que é uma aproximação (linear) da realidade, o que pode levar a resultados distorcidos. As funções de produção têm um formato que normalmente distancia-se do linear. A "proxy" oferecida por esses modelos é relevante para a construção dos modelos quadráticos, nos quais os pontos iniciais são fornecidos pelo modelo linear. 
As aproximações feitas no processo de linearização do modelo distorcem os resultados à medida que se distanciam dos pontos esperados. Por este motivo, o modelo quadrático é uma alternativa interessante e sua utilização pode resultar em valores mais próximos dos reais.

\subsubsection{Modelo Quadrático}

Peres (1976), Nydene (1999) e Silva \& Stulp (2000) trabalham com as variâncias e covariâncias dos desvios em relação à média. O trabalho de Stulp (2000) busca alternativas para incorporar ao modelo as tendências das séries. No presente estudo, estão sendo utilizadas as variâncias e covariâncias dos desvios das séries em relação às respectivas retas de regressão estimadas com base em modelo no qual a variável dependente é a receita bruta e a explicativa é a tendência.

Os efeitos compensatórios em termos de desvios são desejáveis para a formação de um portfólio. O trabalho de Nydene et al. (1999) sugere que os modelos de médiavariância oferecem melhor ajuste para a análise de produtos agrícolas.

\subsection{Resultados do Mato Grosso}

Os resultados do modelo quadrático para o Mato Grosso são, em linhas gerais, semelhantes aos resultados do modelo linear (Tabela 35). No entanto, fica evidente que o ajustamento é mais próximo daquele verificado na realidade.

A propriedade tem receita líquida máxima - $\mathrm{R} \$ 385$ mil - quando aloca todos os recursos disponíveis para o algodão e pecuária. No modelo de média-variância, no ponto 
de máxima receita líquida, o produtor toma recursos do crédito rural no montante suficiente para o plantio de 65 hectares de algodão, sendo que a área total alocada para essa cultura é de 399 hectares. Para a soja, são alocados apenas 7,92 hectares, sendo essa área totalmente financiada com crédito oficial. A área remanescente da propriedade é ocupada pela pecuária de corte. Apresentando um comportamento semelhante ao verificado no modelo linear de risco, o número de atividades na propriedade identificado pelo modelo quadrático é maior do que o adotado em condições de indiferença ao risco.

À medida que a receita líquida esperada é reduzida, a composição de produtos sofre alteração com o crescimento progressivo da área de soja. Com uma receita bruta esperada de $\mathrm{R} \$ 300$ mil, a área de soja é duas vezes maior que a área de algodão. Este crescimento se dá em detrimento da área alocada para pecuária de corte e algodão. A pecuária tem sua área reduzida em $14,25 \%$ considerando o ponto associado à receita de $\mathrm{R} \$ 300$ mil relativamente ao ponto de $\mathrm{R} \$ 380$ mil, e o algodão em $15,97 \%$. Os dados indicam que a inclusão da soja, que apresenta menor variabilidade da receita bruta, ocorre no sentido de reduzir a exposição ao risco. Nas faixas de menor receita líquida esperada, o crescimento da área ocupada com pecuária de corte é nítido, bem como a redução da área de algodão. Isso é perfeitamente explicável pela variabilidade associada ao algodão e à pecuária.

A área alocada com cada uma das atividades é influenciada pelas variabilidades da receita bruta e pela receita líquida da atividade. Esses dois fatores são alterados pelos sistemas de crédito e de comercialização, privado ou estatal, e por incentivos fiscais.

O crédito rural é utilizado somente quando os retornos líquidos estão em patamares mais elevados. Em níveis de retornos menores, o modelo sugere que apenas os recursos próprios devam ser utilizados.

As intervenções do governo nos mercados dos produtos agropecuários são incorporadas ao modelo através dos preços. $\mathrm{O}$ algodão conta com um incentivo fiscal do Imposto sobre Circulação de Mercadorias e Serviços (ICMS) oferecido pelo governo do estado do Mato Grosso, sendo que essa medida possibilita a devolução de até $75 \%$ do 
total de imposto pago. Isto é incorporado no preço, acarretando uma elevação da rentabilidade líquida do produto por hectare. $\mathrm{O}$ milho e o algodão são favorecidos pela política de "Opção de Venda" do governo federal, na qual o produtor tem a possibilidade de adquirir o direito de entregar o produto ao governo.

A pecuária de corte não é beneficiada por política pública. Esta atividade conta apenas com um mercado futuro desenvolvido, o que possibilita aos produtores fixarem posições de médio prazo. Essa possibilidade, contudo, não está incorporada ao modelo, pois nos painéis realizados não se verificaram transações dessa natureza.

A soja tem como opção a venda antecipada do produto, ou seja, conta com a possibilidade de ser comercializada num sistema que se aproxima do mercado a termo, fato que não foi incorporado de forma direta no modelo. Essas transações têm ocorrido principalmente nos últimos anos e constituem-se numa alternativa de financiamento para os produtores. A rentabilidade líquida da soja incorpora, em alguma medida, essa opção de financiamento, já que nas planilhas de custo o preço dos insumos é formado considerando o processo de venda antecipada do produto.

Tabela 35. Modelo quadrático aplicado no Mato Grosso.

\begin{tabular}{lllll}
\hline Receita & Variância & Atividades & Área (ha) & Crédito (ha) \\
\hline 385000 & $9,31 \mathrm{E}+10$ & Soja direto & 7,92 & 7,923 \\
& & Algodão & 399,71 & 65,072 \\
& Pecuária de corte & 2592,36 & - \\
& Cob1 & 7,92 & - \\
& Cob12 & 399,71 & - \\
380000 & Cob56 & 7,92 & - \\
& & & \\
& \multirow{4}{*}{$9,01 \mathrm{E}+10$} & Soja direto & 50,44 & 50,44 \\
& & Algodão & 393,64 & 47,15 \\
& & Pecuária de corte & 2555,91 & - \\
& Cob1 & 50,44 & -
\end{tabular}


Tabela 35. Modelo quadrático aplicado no Mato Grosso.

\begin{tabular}{|c|c|c|c|c|}
\hline Receita & Variância & Atividades & Área (ha) & Crédito (ha) \\
\hline & & Cob12 & 393,65 & - \\
\hline & & Cob56 & 50,44 & - \\
\hline \multirow[t]{6}{*}{350000} & $7,45 \mathrm{E}+10$ & Soja direto & 305,55 & 75,217 \\
\hline & & Algodão & 357,224 & - \\
\hline & & Pecuária de corte & 2337,223 & - \\
\hline & & Cob1 & 305,553 & - \\
\hline & & Cob12 & 357,224 & - \\
\hline & & Cob56 & 305,553 & - \\
\hline \multirow[t]{6}{*}{300000} & $5,88 \mathrm{E}+10$ & Soja direto & 695,31 & - \\
\hline & & Algodão & 300,096 & - \\
\hline & & Pecuária de corte & 2004,58 & - \\
\hline & & Cob1 & 695,31 & - \\
\hline & & Cob12 & 300,96 & - \\
\hline & & Cob56 & 695,31 & - \\
\hline \multirow[t]{8}{*}{50000} & $4,95 \mathrm{E}+10$ & Soja direto & 668,852 & - \\
\hline & & Algodão & 291,96 & - \\
\hline & & Pecuária de corte & 1811,996 & - \\
\hline & & Cob1 & 668,852 & - \\
\hline & & Cob12 & 519,152 & - \\
\hline & & Cob3 & 227,192 & - \\
\hline & & Cob34 & 227,192 & - \\
\hline & & Cob56 & 896,044 & - \\
\hline \multirow[t]{5}{*}{200000} & $4,11 \mathrm{E}+10$ & Soja direto & 603,79 & - \\
\hline & & Algodão & 288,39 & - \\
\hline & & Pecuária de corte & 1631,607 & - \\
\hline & & Cob1 & 603,79 & - \\
\hline & & Cob12 & 764,603 & - \\
\hline
\end{tabular}


Tabela 35. Modelo quadrático aplicado no Mato Grosso.

\begin{tabular}{|c|c|c|c|c|}
\hline Receita & Variância & Atividades & Área (ha) & Crédito (ha) \\
\hline & & Cob3 & 476,214 & - \\
\hline & & Cob34 & 476,214 & - \\
\hline & & Cob56 & 1080,004 & - \\
\hline \multirow[t]{8}{*}{150000} & $3,35 \mathrm{E}+10$ & Soja direto & 538,72 & - \\
\hline & & Algodão & 284,42 & - \\
\hline & & Pecuária de corte & 1451,21 & - \\
\hline & & Cob1 & 581,728 & - \\
\hline & & Cob12 & 1010,054 & - \\
\hline & & Cob3 & 725,235 & - \\
\hline & & Cob34 & 725,235 & - \\
\hline & & Cob56 & 1263,963 & - \\
\hline \multirow[t]{8}{*}{100000} & $2,67 \mathrm{E}+10$ & Soja direto & 473,666 & - \\
\hline & & Algodão & 281,249 & - \\
\hline & & Pecuária de corte & 1270,828 & - \\
\hline & & Cob1 & 473,666 & - \\
\hline & & Cob12 & 1255,506 & - \\
\hline & & Cob3 & 974,256 & - \\
\hline & & Cob34 & 974,256 & - \\
\hline & & Cob56 & 1447,922 & - \\
\hline \multirow[t]{8}{*}{50000} & $2,07 E+10$ & Soja direto & 408,604 & - \\
\hline & & Algodão & 277,679 & - \\
\hline & & Pecuária de corte & 1090,439 & - \\
\hline & & Cob1 & 408,6084 & - \\
\hline & & Cob12 & 1500,957 & - \\
\hline & & Cob3 & 1223,278 & - \\
\hline & & Cob34 & 1223,278 & - \\
\hline & & Cob56 & 1631,882 & - \\
\hline
\end{tabular}

Fonte: Resultados da pesquisa. 
A pecuária de corte e o algodão aparecem em praticamente todos os pontos estabelecidos para retorno líquido. A participação dessas duas atividades na composição de todos esses portfólios de produção é explicada pelo elevado retorno que a cultura do algodão ofereceu no ano-safra de referência e pela pequena variabilidade da receita bruta da pecuária ao longo da série histórica considerada na análise. O algodão, na safra de referência, apresentou retorno líquido de $\mathrm{R} \$ 898,00$ por hectare, sendo quase oito vezes mais rentável que a soja. A pecuária, por sua vez, apresentou retorno líquido de $\mathrm{R} \$$ 18,00 por hectare, o menor retorno entre as atividades.

O algodão, conforme já discutido, é uma atividade que depende de grandes investimentos em máquinas e também para o controle de pragas, fatores que tornam a atividade seletiva e, conseqüentemente, com receita líquida elevada comparativamente a outras. No caso da pecuária, o cenário é inverso: demanda pouco investimento e possibilita a entrada de novos produtores quando as condições de mercado mostram-se favoráveis, o que propicia menor rentabilidade. A pecuária é uma atividade associada à reserva de valor e liquidez na propriedade agrícola.

\subsection{Resultados do Rio Grande do Sul}

As propriedades do Rio Grande do Sul têm menor número de atividades potenciais que possam ser utilizadas no processo de diversificação. A receita líquida máxima dos produtores é de $\mathrm{R} \$ 170 \mathrm{mil}$, considerando as limitações de recursos definidas nos painéis. A cultura do milho tem variabilidade maior que a da soja, mas na safra analisada, 2000/01, apresentou maior retorno líquido por hectare. O trigo também apresentou um rendimento maior nesta safra. 
No caso destes dois produtos, é interessante destacar que ambos têm históricos de intervenção do Estado no processo de formação dos preços. O milho sempre esteve envolto em políticas do tipo AGF e EGF do governo federal, conforme já discutido no caso do Mato Grosso, e o trigo também contou com políticas de manutenção de preços. A soja e a pecuária de corte, ao contrário, nunca tiveram apoio dessa natureza. Nas últimas safras, o governo não tem participado do processo de comercialização do trigo, mas os preços deste produto foram favorecidos pela desvalorização cambial.

O produtor de soja nos últimos anos tem tido a possibilidade de fazer vendas antecipadas, com a fixação de preços, como no caso do Mato Grosso. Isto lhe permite eliminar os riscos das oscilações indesejáveis dos preços. No caso da pecuária de corte, existe o mercado futuro ativo, que permite o gerenciamento dos riscos de preços. No modelo, assim como foi feito para o caso do Mato Grosso, não foram incorporados de forma direta esses mecanismos de gerenciamento de riscos.

Os resultados do modelo E-V para a propriedade típica do Rio Grande do Sul estão apresentados na Tabela 36. Esses resultados são semelhantes aos encontrados no caso do modelo linear de risco, sendo que, em ambas regiões, o produtor, mesmo nos níveis mais elevados da renda líquida esperada, adota mais atividades do que no modelo sem a inclusão do risco. Portanto, o processo de diversificação é fundamental para a redução dos riscos. 
Tabela 36. Modelo quadrático aplicado no Rio Grande do Sul.

\begin{tabular}{|c|c|c|c|c|}
\hline Receita & Variância & Atividades & Área (ha) & Crédito (ha) \\
\hline \multirow[t]{9}{*}{20000} & $1,35 E+09$ & Milho & 35,97 & - \\
\hline & & Soja direto & 69,76 & - \\
\hline & & Trigo & 15,09 & - \\
\hline & & Pecuária de corte & 0 & - \\
\hline & & Cob12 & 184,9 & - \\
\hline & & Cob3 & 94,26 & - \\
\hline & & Cob34 & 94,26 & - \\
\hline & & Cob56 & 94,26 & - \\
\hline & & Cob6 & 90,64 & - \\
\hline \multirow[t]{9}{*}{30000} & $1,88 \mathrm{E}+09$ & Milho & 42,56 & - \\
\hline & & Soja direto & 82,55 & 50,44 \\
\hline & & Trigo & 17,86 & - \\
\hline & & Pecuária de corte & 0 & - \\
\hline & & Cob12 & 182,13 & - \\
\hline & & Cob3 & 74,88 & - \\
\hline & & Cob34 & 74,88 & - \\
\hline & & Cob56 & 74,88 & - \\
\hline & & Cob6 & 107,255 & - \\
\hline \multirow[t]{9}{*}{50000} & $3,23 \mathrm{E}+09$ & Milho & 55,75 & - \\
\hline & & Soja direto & 108,125 & 75,217 \\
\hline & & Trigo & 23,394 & - \\
\hline & & Pecuária de corte & 0 & - \\
\hline & & Cob12 & 176,606 & - \\
\hline & & Cob3 & 36,124 & - \\
\hline & & Cob34 & 36,124 & - \\
\hline & & Cob56 & 36,124 & - \\
\hline & & $\mathrm{Cb} 6$ & 140,481 & - \\
\hline 80000 & $6,11 E+09$ & Milho & 80,657 & - \\
\hline
\end{tabular}


Tabela 36. Modelo quadrático aplicado no Rio Grande do Sul.

\begin{tabular}{|c|c|c|c|c|}
\hline Receita & Variância & Atividades & Área (ha) & Crédito (ha) \\
\hline & & Soja direto & 119,343 & - \\
\hline & & Trigo & 48,877 & - \\
\hline & & Pecuária de corte & 0 & - \\
\hline & & Cob12 & 151,123 & - \\
\hline & & Cob6 & 151,123 & - \\
\hline \multirow[t]{6}{*}{100000} & $9,49 E+09$ & Milho & 102,868 & - \\
\hline & & Soja direto & 97,132 & - \\
\hline & & Trigo & 84,662 & - \\
\hline & & Pecuária de corte & 0 & - \\
\hline & & Cob12 & 115,338 & - \\
\hline & & Cob6 & 115,338 & - \\
\hline \multirow[t]{6}{*}{120000} & $1,43 \mathrm{E}+09$ & Milho & 125,079 & - \\
\hline & & Soja direto & 74,921 & - \\
\hline & & Trigo & 120,447 & - \\
\hline & & Pecuária de corte & 0 & - \\
\hline & & Cob12 & 79,553 & - \\
\hline & & Cob6 & 79,553 & - \\
\hline \multirow[t]{6}{*}{150000} & $2,44 \mathrm{E}+10$ & Milho & 160,045 & - \\
\hline & & Soja direto & 39,955 & - \\
\hline & & Trigo & 172,561 & - \\
\hline & & Pecuária de corte & 0 & - \\
\hline & & Cob12 & 27,439 & - \\
\hline & & Cob6 & 27,439 & - \\
\hline \multirow[t]{4}{*}{160000} & $2,85 \mathrm{E}+10$ & Milho & 171,469 & - \\
\hline & & Soja direto & 28,531 & - \\
\hline & & Trigo & 190,569 & - \\
\hline & & Pecuária de corte & 0 & - \\
\hline
\end{tabular}


Tabela 36. Modelo quadrático aplicado no Rio Grande do Sul.

\begin{tabular}{lllll}
\hline Receita & Variância & Atividades & Área (ha) & Crédito (ha) \\
\hline & & Cob12 & 9,431 & - \\
& Cob6 & 9,431 & - \\
\multirow{4}{*}{170000} & \multirow{2}{*}{$3,30 \mathrm{E}+10$} & Milho & 186,683 & - \\
& & Soja direto & 13,317 & - \\
& & Trigo & 200 & - \\
& & Pecuária de corte & 0 & - \\
\hline
\end{tabular}

Fonte: Resultados da pesquisa

A receita máxima atingida pelos produtores gaúchos, considerando os recursos disponíveis, é de $R \$ 170$ mil. Da área total, cerca de 186 hectares são alocados para milho, 13 para soja e 200 para trigo. Com a redução da receita líquida esperada, a área alocada para soja cresce em detrimento da área de milho. No intervalo de receita líquida esperada entre $R \$ 100$ mil e $R \$ 80$ mil, a área de milho e soja praticamente se igualam, aproximando-se da situação real.

No nível de renda mais baixo, $\mathrm{R} \$ 20$ mil, a soja se torna a principal cultura de verão, com 69 hectares, contra 35 hectares do milho, confirmando que a soja tem menor variabilidade de receita que o milho. O trigo aparece em apenas 15 hectares. Esse resultado comprova que a diversificação de atividade reduz os riscos, mas ao custo de uma diminuição da renda do produtor.

A propriedade típica da região tem 75 hectares de milho, 95 hectares de soja, 56 hectares de trigo e 20 hectares de pecuária, conforme levantado no painel. No modelo quadrático, o conjunto de atividades econômicas que mais se aproxima da composição observada na propriedade típica propicia $\mathrm{R} \$ 80$ mil de retorno líquido. Nos resultados obtidos da modelagem quadrática, a área alocada para soja é de 119 hectares, o milho ocupa 80 hectares e o trigo 48 hectares. A pecuária de corte não aparece entre as atividades identificadas no modelo como viáveis. 


\subsection{Fronteiras eficientes}

A fronteira de eficiência econômica é definida como um conjunto de pontos dentro do espaço de retorno e risco no qual a empresa atinge o melhor retorno, dentro das limitações dos fatores de produção. A construção da fronteira eficiente pode ser feita utilizando-se o MOTAD e o modelo quadrático. O formato da curva depende das restrições de insumos e recursos da propriedade.

Nas Figuras 10 e 11 estão apresentadas as fronteiras eficientes dos modelos lineares dos estados do Mato Grosso e do Rio Grande do Sul.

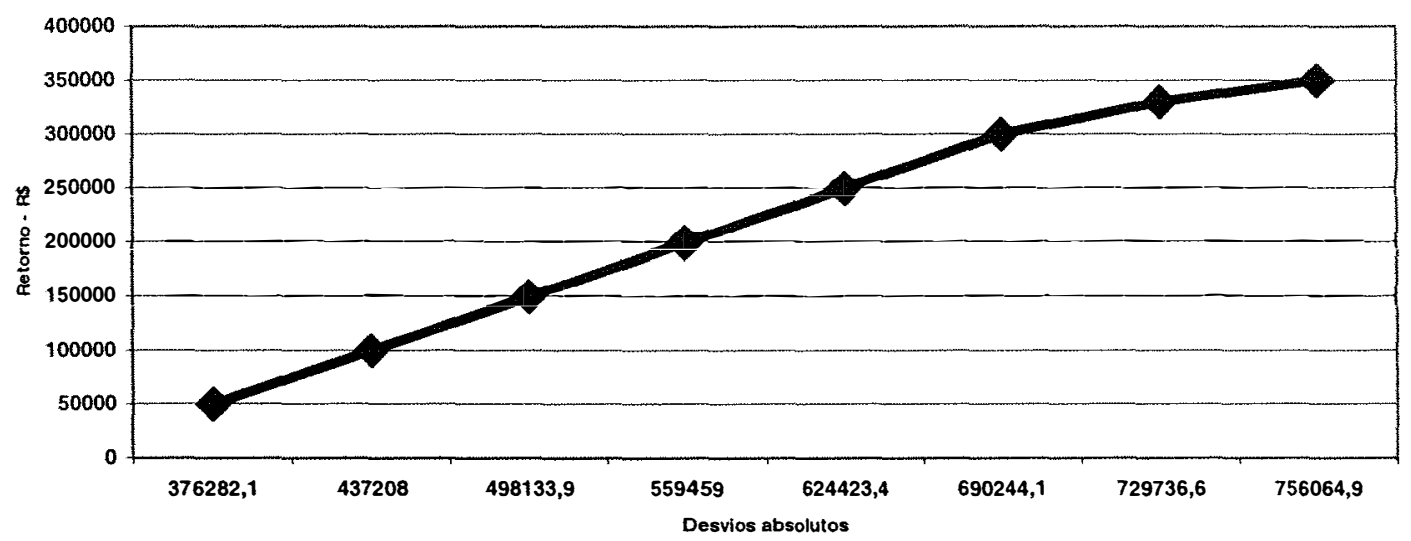

Figura 10 - Retorno e desvio absoluto no Mato Grosso - MOTAD.

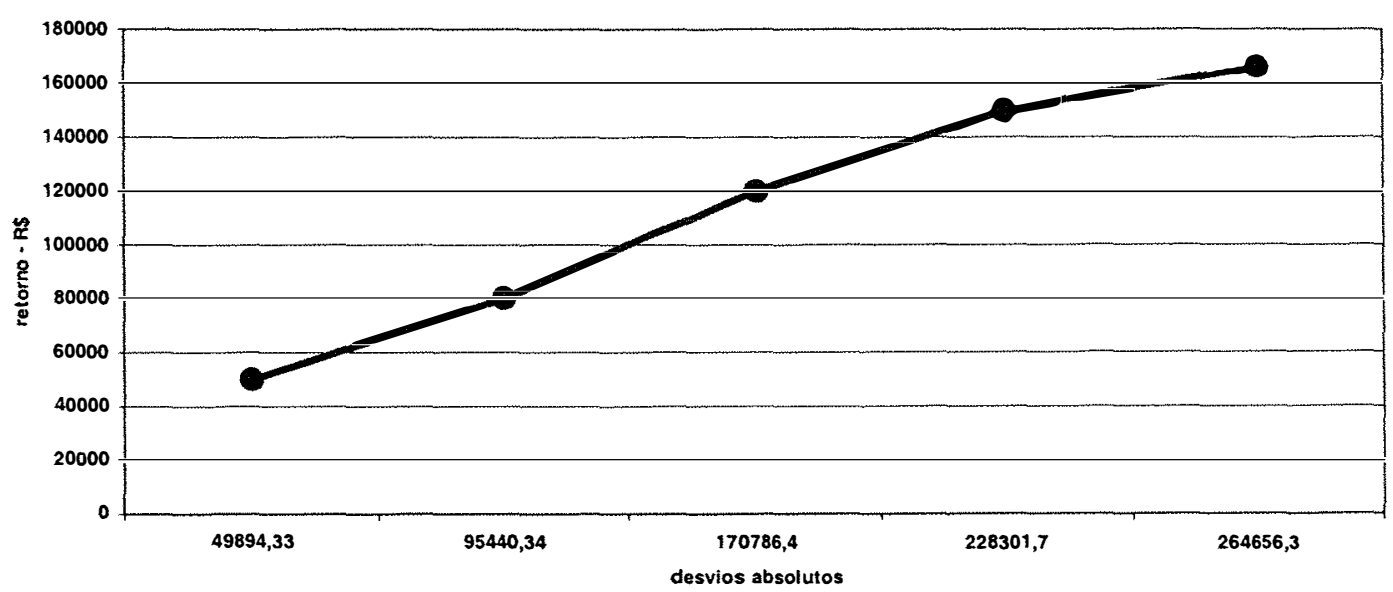

Figura 11 - Retorno e desvio absoluto no Rio Grande do Sul - MOTAD. 
A curva do Mato Grosso tem o formato típico de uma propriedade de grande porte, cerca de 3.000 hectares, com várias opções de culturas anuais mais uma de ciclo curto (segunda safra). Teoricamente, as propriedades com as mesmas características consideradas no modelo devem estar posicionadas sobre essa curva para atingirem o ponto ótimo de eficiência econômica.

O mesmo é válido para o gráfico do Rio Grande do Sul, mas a curva representa uma propriedade de menor tamanho, cerca de 200 hectares, situada numa região onde as condições climáticas oferecem apenas duas opções para culturas de inverno e verão. Os gráficos da fronteira eficiente dos modelos quadráticos, para as propriedades do Rio Grande do Sul e Mato Grosso, estão apresentados nas Figuras 12 e 13.

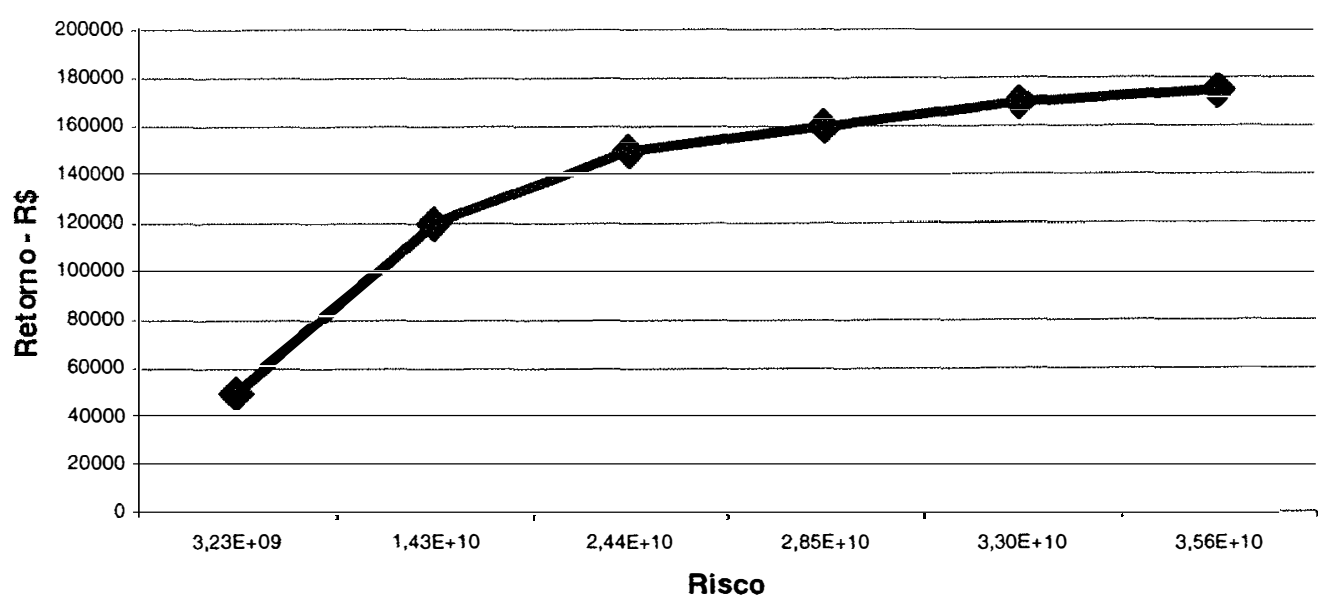

Figura 12 - Fronteira eficiente no Rio Grande do Sul - modelo E-V.

A curva do modelo E-V para o Rio Grande do Sul apresenta uma inclinação mais acentuada para os menores níveis de renda, o que significa que pequenos aumentos da renda estão associados a grandes aumentos nos riscos. 


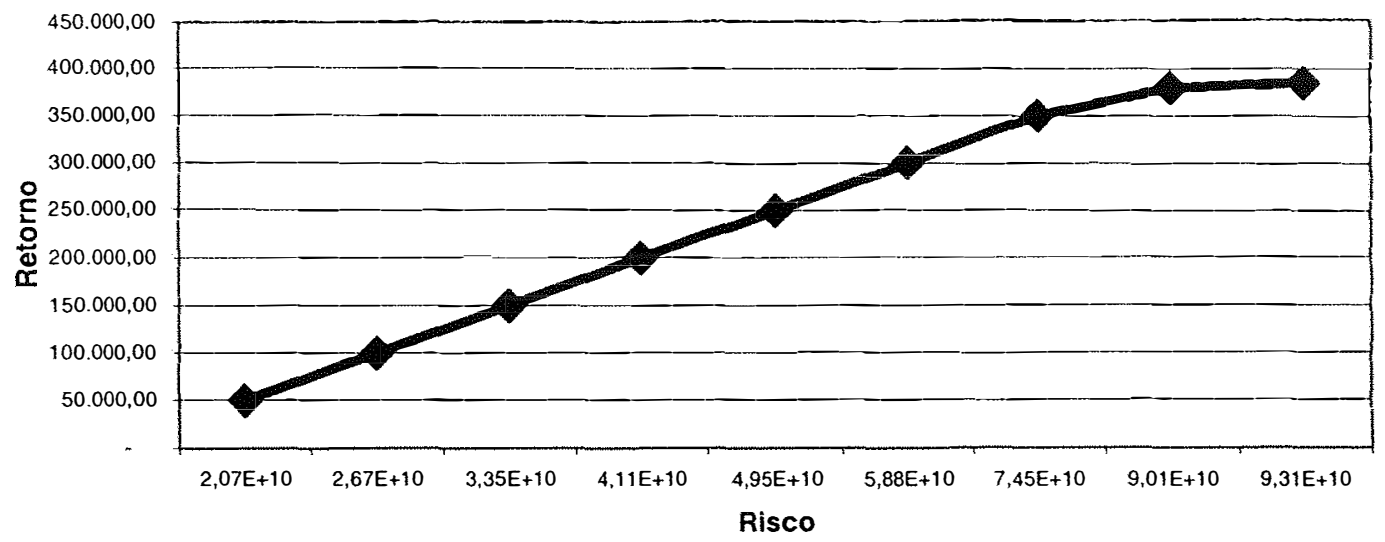

Figura 13 - Fronteira eficiente no Mato Grosso - modelo E-V.

A curva do Mato Grosso apresenta comportamento distinto. Nas menores faixas de retorno líquido esperado, a relação entre risco e retorno cresce mais lentamente que nos níveis mais elevados. Isso pode ser atribuído ao maior número de atividades econômicas potenciais da região. Nas camadas de baixa rentabilidade, os produtores trocam menores quantidades de renda por maiores retornos.

Na curva dos resultados do Rio Grande do Sul, nota-se uma maior inclinação nas primeiras faixas de renda esperada. Essas diferenças entre o formato das curvas desses dois estados podem estar relacionadas a características estruturais das propriedades, climáticas, comerciais e, ainda, a fatores culturais.

A inclinação da reta no ponto em que os produtores têm um "mix" de produção que se aproxima do identificado no modelo teórico fornece a taxa de aversão ao risco que caracteriza esses produtores. Na seqüência, discutem-se as taxas de aversão ao risco dos produtores de cada uma das regiões de estudo. 


\subsection{Taxa de aversão ao risco}

A fronteira eficiente representa, como já foi definido, as diferentes combinações de atividades nas quais os produtores obtêm a receita máxima com os fatores de produção que dispõem, dentro contexto de risco e retorno. Portanto, qualquer ponto ao longo dessa curva é considerado de máxima eficiência. Com os dados dos painéis, é possível identificar o local onde a curva de utilidade do produtor tangencia a fronteira e, neste ponto, deve estar situada a propriedade típica. A inclinação da fronteira eficiente neste ponto fornece a taxa de aversão ao risco do produtor. Na Figura 14, tem-se a demonstração gráfica do processo de definição da taxa de aversão ao risco. Cada um dos pontos da fronteira eficiente tem uma inclinação própria, portanto uma taxa de aversão ao risco diferente.

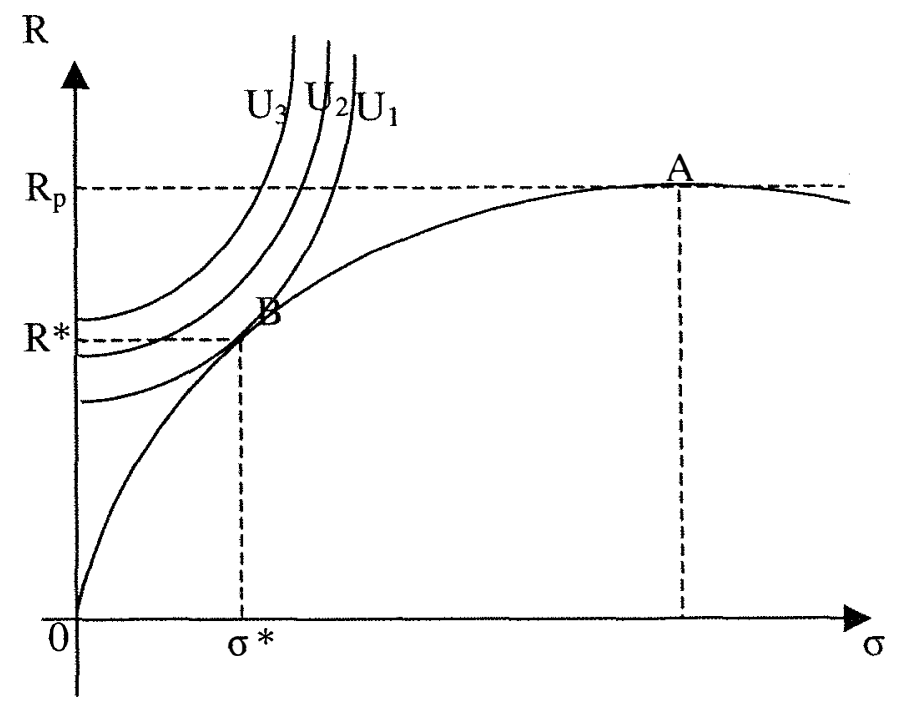

Figura 14 - Maximização da Utilidade. 
O ponto B, na Figura 14, é o local em que a curva de utilidade do produtor tangencia a fronteira eficiente. Neste ponto, está um conjunto de atividades que o produtor adota para atingir a renda desejada, aceitando um determinado nível de risco.

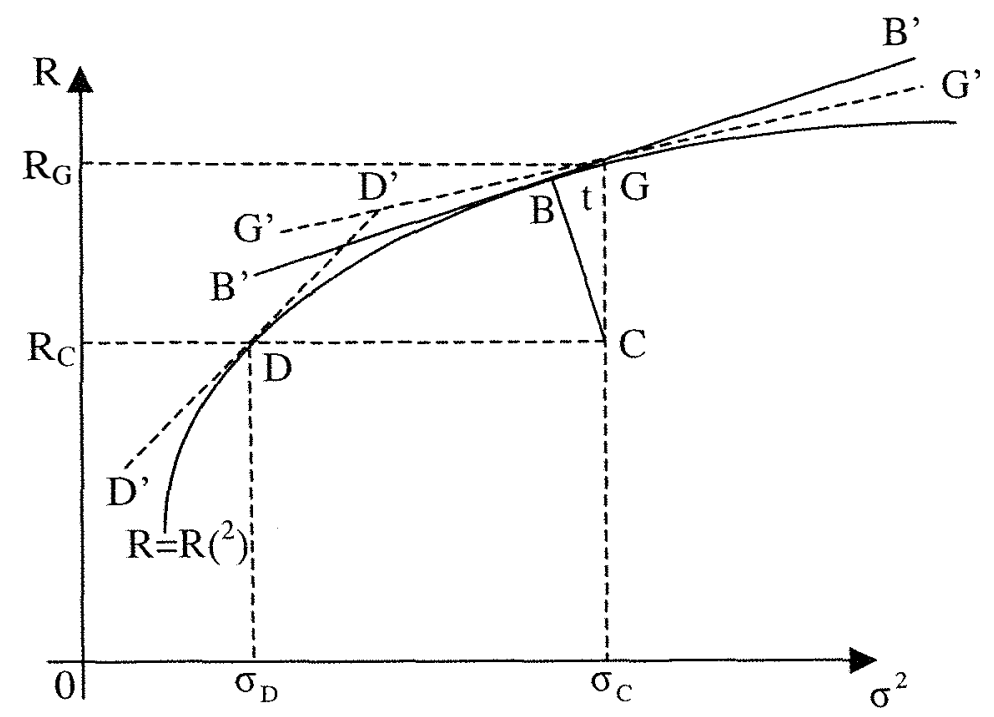

Figura 15 - Inclinação das tangentes dos pontos dos portfólios de produção.

Nas Figuras 16 e 17, estão colocados os pontos onde as curvas de utilidade dos produtores mato-grossense e gaúchos tangenciam as respectivas fronteiras eficientes.

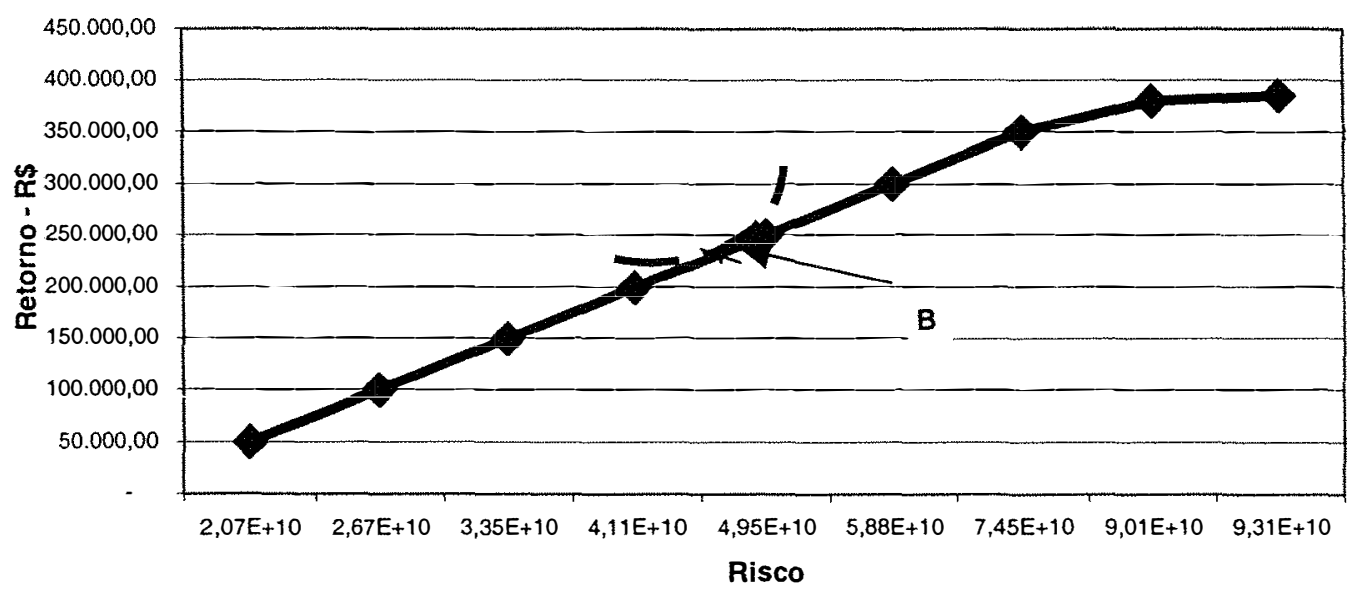

Figura 16 - Fronteira eficiente - Mato Grosso - Modelo E-V. 


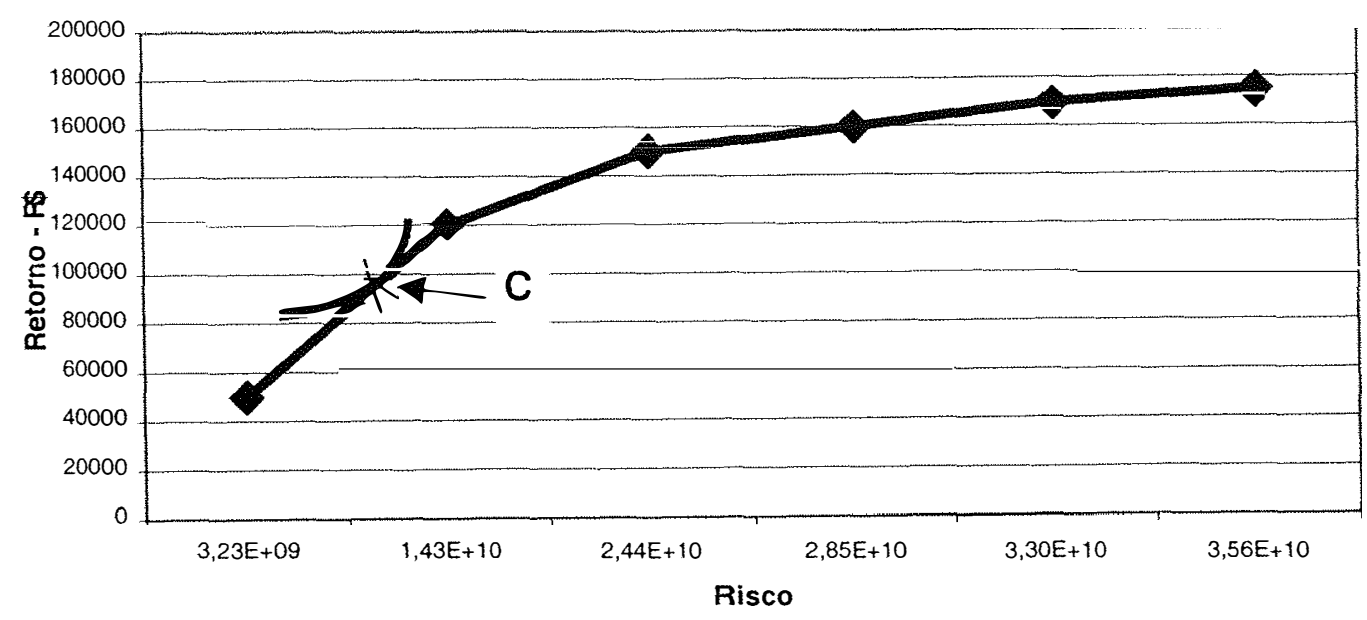

Figura 17 - Fronteira eficiente - Rio Grande do Sul - Modelo E-V.

$\mathrm{O}$ ponto $\mathrm{C}$ corresponde a uma renda líquida de $\mathrm{R} \$ 90$ mil para um produtor gaúcho e, o ponto $\mathrm{B}$ corresponde a $\mathrm{R} \$ 220$ mil para um produtor mato-grossense. A inclinação da fronteira eficiente nestes pontos fornece a taxa de aversão ao risco dos dois produtores. Quanto maior a inclinação maior a taxa de aversão ao risco do produtor.

No ponto B da Figura 16, onde a curva de utilidade dos produtores do Mato Grosso tangencia a fronteira eficiente, a inclinação da reta que tangencia o ponto indica a taxa de aversão ao risco do produtor. No caso, a taxa de aversão ao risco é de 5,42 x $10^{-6}$.

A curva de utilidade do produtor do Rio Grande do Sul tangencia a fronteira eficiente no ponto $C$ da Figura 17, indicando que a sua taxa de aversão ao risco é de 6,32 $\times 10^{-6}$.

A taxa de aversão ao risco é maior para o produtor gaúcho que para o produtor mato-grossense. Isso era esperado, uma vez que a estrutura de produção do Sul é mais estável que a do Mato Grosso. O Rio Grande do Sul não tem novas áreas a serem abertas, como existem no Mato Grosso. Além disso, o produtor gaúcho tem, 
proporcionalmente ao volume de recursos total necessário, mais capital próprio e maior disponibilidade de crédito rural oficial. 


\section{CONCLUSÕES}

Alguns setores da agricultura brasileira atingiram, nos últimos anos, um patamar de competitividade bastante elevado. Tal evolução ocorreu em um período em que o Estado passou a ter uma postura mais passiva e os, produtores, por sua vez, procuraram por conta própria modificar as estruturas de produção, adaptando-se às forças do mercado e às demandas por competitividade interna e externa.

Neste trabalho, estudaram-se duas regiões - Mato Grosso e Rio Grande do Sul distintas tanto em termos de estruturas de produção quanto de infra-estrutura disponível, mas ambas caracterizadas pela prática da atividade agrícola em moldes empresariais. O fator comum entre as duas regiões é a identificação de um otimismo dos produtores em relação à atividade agrícola como um todo. Os produtores que participaram dos painéis demonstraram desprendimento da tradicional postura passiva e dependente das ações do Estado e assumiram um comportamento ativo de busca de soluções para seus próprios problemas.

$\mathrm{Na}$ grande maioria dos casos, a atitude verificada da parte dos produtores é a de enfrentar decididamente os desafios: "o problema é este e nós faremos isto para resolvêlo". Por se tratar de uma observação de corte seccional, não se pode dizer, no entanto, que esta seja uma nova e permanente postura ou que se resuma a uma alteração circunstancial do forma de decisão dos produtores. 
O empresário agrícola estudado, principalmente do Mato Grosso, é um agente econômico rico em experiências de vida e com grande capacidade de superar dificuldades. As novas tecnologias estão sendo sempre experimentadas e testadas, sendo adotadas quando por ele aprovadas. A informação tecnológica e de mercado é uma questão vital. A preocupação com a competitividade é constante, ou seja, é fundamental reduzir custos de produção para ter o produto colocado no Sudeste ou exportado, incorporando pesados impostos e fretes.

Aliás, a atenção dada aos custos de produção no Mato Grosso aparenta ser muito maior do que no Sul. As dimensões financeiras das propriedades mato-grossenses também exigem um controle mais avançado de custo. A dependência de capital próprio ou do dinheiro a custo de mercado faz do agricultor do Centro-Oeste um empresário mais atento aos fluxos financeiros. Empiricamente, isto transparece na observação de que as maiores limitações na propriedade mato-grossense são de capital, enquanto na propriedade gaúcha é de área disponível. O crédito oficial atende às demandas do produtor do Rio Grande do Sul, mas é insuficiente para as necessidades do produtor do Mato Grosso.

Deve-se, também, mencionar a limitação quanto à natureza dos dados utilizados: séries históricas relevantes - capazes de captar as mudanças recentes - para a região do Mato Grosso são escassas. Esse é um fator determinante para o tipo de procedimento de obtenção de dados de boa qualidade: a coleta diretamente junto aos produtores, com intensa participação e muito questionamento para verificação da validade das informações.

Os modelos, tanto os lineares quanto os quadráticos, mostram que o produtor brasileiro, independente de suas dimensões, não está indiferente ao risco de suas atividades. Os resultados do modelo de maximização da receita líquida - fase inicial do processo de ajuste dos modelos, em que se considera que o produtor está indiferente ao risco das atividades - ficam distantes da composição de atividades observadas nas propriedades estudadas. 
A maximização da receita líquida das propriedades preconiza investimentos nas atividades mais rentáveis; mas, freqüentemente, as atividades mais rentáveis estão associadas a grandes variabilidades da receita e, por conseguinte, a grandes riscos. Por esse motivo, a composição do conjunto de atividades que maximiza a receita líquida está distante do conjunto observado no campo.

Os produtores têm consciência de tal relação e procuram atividades em função do grau de remuneração, mas sem perder de vista os riscos. O produtor do Mato Grosso está ciente do retorno médio alto que a cultura do algodão oferece, mas também sabe que, nesta cultura, o investimento está cercado de muitos fatores de risco.

O fato em si da experiência com a cultura do algodão ser curta no Mato Grosso já é um fator que desperta insegurança no produtor. Por esse motivo, ele reconhece que se trata de um produto atraente, mas entra na atividade com muita cautela. Neste caso, é importante ressaltar que o governo do estado do Mato Grosso deu um passo importante para o desenvolvimento da cultura quando definiu que $1 \%$ do ICMS do algodão deveria ser entregue a uma instituição de pesquisa administrada pelos produtores. Desta forma, criou-se a Fundação Mato Grosso, cuja principal atribuição é o desenvolvimento e adaptação de novas variedades.

Este tipo de ação tem efeitos de longo prazo, mas a história recente do algodão já mostra que a crise causada por problemas fitossanitários, que atingiu a lavoura goiana na safra 1997/1998, não afetou a cultura no Mato Grosso, pois os produtores desse estado já estavam preparados e alertados pelas instituições de pesquisa. Isso implica em menor variabilidade da produtividade no Mato Grosso do que em Goiás, por exemplo.

A soja tem menor variabilidade da receita bruta e, logo, representa menores riscos. O produtor sabe que esta cultura, além da grande liquidez, oferece ainda a possibilidade de antecipação de recursos. Os resultados dos modelos da propriedade mato-grossense mostram que essa possibilidade é compatível com a otimização da renda líquida, uma vez que a área de soja preconizada nos modelos aproxima-se da verificada 
nos trabalhos de campo. Frente a essa alternativa, o produtor, entretanto, não abandona totalmente a cultura do algodão, mas busca um processo de integração de atividades.

No conjunto de atividades, aparece ainda a pecuária de corte, presente em todos os modelos do Mato Grosso. Os produtores, em geral, têm muita terra e pouco capital. Por isso, é comum a adoção de alternativa que busca uma atividade extensiva de baixo risco e baixo custo, que proporcione o uso da terra abundante, garantindo a propriedade da área. Este conjunto de atividades tem riscos menores com redução na rentabilidade. Portanto, o produtor mato-grossense não é indiferente aos riscos e utiliza a diversificação como uma forma de redução de riscos. Além disso, visa a ocupação de toda a área e o equilíbrio do fluxo de caixa.

No Rio Grande do Sul, os produtores também adotam a diversificação com os mesmos objetivos. O modelo que maximiza a renda líquida do agricultor tem a solução ótima com a alocação de toda área para milho, no verão, e para trigo, no inverno. Porém, isto não é efetivamente observado no campo. O produtor gaúcho opta por mais produtos na composição de seu portfólio. Também fica claro que o produtor não é indiferente ao risco, preferindo dividir a terra entre soja e milho no verão e entre trigo e pecuária no inverno.

O modelo que leva em conta o risco das atividades não inclui a pecuária de corte em nenhum ponto da fronteira de eficiência econômica. Isso pode ser creditado ao fato de que esse produtor pode estar abaixo da fronteira eficiente e, portanto, aquém da combinação que teoricamente seria mais recomendada. Essa é uma primeira conclusão que desperta para a idéia que o trabalho deve ser continuado, uma vez que os produtores não são irracionais ao ponto de adotarem uma atividade que lhes proporcione uma situação econômica inferior à melhor possível .

O modelo deve ser aprofundado para que essa afirmativa possa ser sustentada. Isto poderia ser feito mediante a incorporação, no modelo, de informações relativas à variabilidade dos custos, ou seja, proceder à mensuração dos riscos através dos desvios da receita líquida e não somente da receita bruta. 
Além disto, é importante ressaltar que diferentemente do caso do Mato Grosso, no modelo para o Rio Grande do Sul, a produtividade da pecuária foi incorporada no cálculo da receita bruta. No caso do Mato Grosso, apenas os preços são variáveis ao longo da série histórica da receita bruta, posto que a variação da produtividade da pecuária de corte dificilmente é percebida pelos produtores desse estado, uma vez que é de difícil mensuração e depende muito do sistema produtivo adotado. Já no Rio Grande do Sul, a produtividade da pecuária de corte pode ser mensurada porque o sistema de produção adota as culturas de inverno como principal fonte de alimento e estas estão sujeitas a variações climáticas. Além disso, o período de produção é curto, não possibilitando a recuperação em outras etapas. No Mato Grosso, o sistema de produção é mais extensivo, as pastagens sofrem menos com os fatores climáticos, pois o período de produção é mais longo e pode ser corrigido à medida que as condições climáticas se alteram.

O produtor gaúcho, em geral, usa áreas de alta declividade para pecuária e considera apenas os valores de entrada e saída dos animais. Neste caso, os animais são considerados como uma reserva de valor e não entram na contabilidade geral da propriedade. No entanto, através das áreas ocupadas com outras atividades agrícolas, é possível verificar que existe um ponto da fronteira eficiente onde a composição das atividades verificadas no campo se aproxima dos resultados do modelo.

Os resultados mostram que o produtor gaúcho tem uma taxa de aversão ao risco maior que o produtor mato-grossense. Isto é bastante consistente com o verificado de maneira empírica, pois o produtor do Sul está numa região onde as estruturas de produção estão consolidadas e a taxa de crescimento dentro da atividade é pouco provável, já que o custo a terra impede a incorporação de novas áreas. No Mato Grosso, as condições são praticamente inversas, sendo que os produtores estão numa fase de grande expansão de área.

Dentre os produtores do Centro-Oeste, é comum encontrar um grande número de pessoas cujas origens estão no Sul do país. Esses produtores trocaram pequenas propriedades no Rio Grande, Santa Catarina e Paraná por grandes áreas no Mato Grosso. 
O abandono da segurança das regiões de origem em busca do novo demonstra grande ousadia e disposição para enfrentar circunstâncias de maior risco.

Os painéis realizados no Mato Grosso foram feitos em regiões onde existe produção significativa de soja, algodão e boi. Os produtores já construíram um considerável patrimônio em máquinas e algumas benfeitorias e, logo, aceitam correr mais riscos que os gaúchos, mas adotam a diversificação como uma forma de amenizálos, uma vez que têm grande capital e não estão dispostos a arriscar-se a perder tudo.

O último ponto a ser destacado é que nos resultados dos modelos, no geral, os produtores não fazem operações de crédito rural. Isto mostra que as taxas de $10 \%$ ao ano, consideradas na modelagem, estão acima do ponto aceito para a atividade. O produtor toma recursos externos quando os níveis de riscos são maiores; em patamares mais baixos e próximos do real, o produtor tende a fazer uso de dinheiro próprio.

No Rio Grande do Sul, os produtores mostram-se preocupados com o fato de que o dinheiro externo representa um grau maior de risco. No Mato Grosso, o dinheiro dos créditos oficiais é insuficiente e burocratizado, sendo mais viável operações de crédito vinculadas à venda antecipada do produto, eliminando, dessa forma, os riscos de oscilações de preços.

Observando os objetivos propostos para este trabalho, é possível verificar que os produtores estão utilizando o processo de diversificação das atividades com duas finalidades: reduzir as oscilações da receita e compor um fluxo de caixa mais estável. Para tanto, estão utilizando as culturas mais tradicionais de suas regiões, mesmo que estas não sejam as mais rentáveis. Nesse processo, a diversificação mostra-se eficiente, principalmente na redução das oscilações da renda, ou seja, dos riscos.

Poder-se-ia ser tentado a concluir que o produtor mato-grossense está sendo mais eficiente que o produtor gaúcho, já que o conjunto de atividades adotado pelos agricultores do Rio Grande do Sul está em um ponto inferior ao ponto teórico ideal. Os produtores do Mato Grosso, por sua vez, estão situados em um ponto sobre a fronteira 
eficiente, logo, estariam no melhor ponto que os recursos disponíveis lhes proporcionam.

Entretanto, adota-se cautela ao esboçar esse tipo de conclusão, posto que os resultados são extremamente dependentes dos dados específicos utilizados na pesquisa e das pressuposições envolvidas no processo de otimização empregados. Somente a repetição deste tipo de estudo, aprimorando a qualidade dos dados e utilizando alternativas outras de modelagem, é que poderá incrementar a robustez dos resultados da pesquisa aqui relatados. 


\section{REFERÊNCIAS BIBLIOGRÁFICAS}

AZEVEDO FILHO, A.B.J.; PERES, C.F. Competitividade da cultura da soja em uma empresa da região de Campinas, SP. Pesquisa Agropecuária Brasileira, v.17, n.4, p.599-605, abr. 1982.

BAKEN, T.G.; GLOY, B.A. A comparison of criteria for evaluating risk management strategies. In: AGRICULTURAL ECONOMICS ANNUAL MEETINGS AT TAMPA, Tampa, 2000. Anais. Tampa : AGRICULTURAL ECONOMICS, 2000, p.1-21.

BARRETT, C.B. On price risk and the inverse farm size-productivity relationship. Madinson: University of Wisconsin-Madison, Department of Agricultural Economics, Dec.1993. p.1-37 (Series Staff Papers)

BARROS, G.S.C. Gastos públicos na agricultura: tendências e prioridades. Brasília: IPEA, 1993. p.1-43. (Estudos de Política Agrícola, 2, Sumários Executivos)

BARROS, G.S.C. Políticas agrícolas: mercados futuros e de opções. Preços Agrícolas, v.113, n.138, p.12-15, 1997. 
BARROS, G.S.C. A transição na política agrícola brasileira. (compact disc) In: CONGRESSO BRASILEIRO DE ECONOMIA E SOCIOLOGIA RURAL, 36., Poços de Caldas, 1998. Anais. Brasília: SOBER, 1998.

BARRY, P.J.; ESCALANTE, C.L.; BAND, S.K. Economic risk and structural characteristics of farm businesses. In: AGRICULTURAL ECONOMICS ANNUAL MEETINGS AT TAMPA, Florida, Aug.2000. Anais. Tampa: AGRICULTURAL ECONOMICS, 2000. p.1-28.

BLACK, D.L.; DORFMAN, J. H. Identifying farmer characteristics related to crop insurance purchase decisions. In: AGRICULTURAL ECONOMICS ANNUAL MEETINGS AT TAMPA, Tampa, Aug. 2000. Anais. Tampa: AGRICULTURAL ECONOMICS, 2000. p.1-51.

BRANDÃO, A.S.P. Efeitos de políticas setoriais e macroeconômicas sobre os incentivos agrícolas. In: CONGRESSO BRASILEIRO DE ECONOMIA E SOCIOLOGIA RURAL, Piracicaba, 1989. Anais. Brasília: SOBER, 1989. p.110142.

CARTES, S. Multiple business ownership in the farm sector: assessing the enterprise and employment contributions of farmers in Cambridgeshire. Journal of Rural Studies, v.15, n.12, p.417-429, 1999.

COBLE, H.K.; BARNETT, B.J. The role of research in producer risk management. Memphis: Mississippi State University, Department of Agricultural Economics, Feb.1999. p.10-27. (Professional Paper Series, 99-001) 
COBLE, H.K.; KNIGHT, T.O.; POPE, R.D.; WILLIANS, J.R. Modeling farm-level crop insurance demand with panel data. American Journal of Agricultural Economics, v.78, n.3, p.439-447, May 1996.

GASQUES, J.G.; VILLA VERDE, C.M. Recursos para a agricultura e a orientação dos gastos públicos. Brasília: IPEA, 1991.p.1-38 (Texto para discussão, n 101 )

GASS, S.I. Linear programming: methods and applications. 3.ed. New York: McGraw-Hill Book Company, 1969. p.358.

HARWOOD, J., HEIFNER, R.; COBLE, K.; PERRY, J.; SOMWARV, A. Managing risk in farming: concepts, research, and analysis. Washington: USDA, Resource Economics Division, 1999. p.1-110 (Agricultural Economic Report, 774)

HAZELL, P.B.R. A linear alternative to quadratic and semi variance programming for farm planning under uncertainty. American Journal of Agricultural Economics, v.53, n.2, p.53-62, Feb. 1971.

MARANGON, L.; DE ZEN, S. Análise do uso de mercados futuros de algodão em substituição ao prêmio de escoamento de produto. (compact disc) In: CONGRESSO BRASILEIRO DE ECONOMIA E SOCIOLOGIA RURAL, 36., Foz do Iguaçu, 1999. Anais. Brasília: SOBER, 1999.

NYDENE C.; PATRICK, G.F.; BAKEN, T.B. The effects of risk management strategies with diversified hog/crop production. In: AMERICAN AGRICULTURAL ECONOMICS ANNUAL MEETINGS AT NASHVILLE, Nashville, Aug.1999. 
Anais.: AMERICAN AGRICULTURAL ECONOMICS, 1999. p.1-31

PERES, F.C. Derived demand for credit under conditions of risk. Ohio, 1976. 141p. Thesis (Ph.D.) - The Ohio State University.

SILVA NETO, B; STUP. V.J. A consideração de tendências na otimização de sistemas de produção. Revista de Economia e Sociologia Rural, v.38, n.3, p.61-80, jul./set. 2000.

TIRUPATTUR, V.; HAUSTER, R.J.; CHAHEELI, N.M. Crop yield and price distributional effects on revenue hedging. Urbana Champain: OFOR, Dec.1996. p.126. (OFOR Paper, 96-05)

VILLA VERDE, C.M. Gastos governamentais voltados para a melhoria da produtividade e competitividade da agricultura. Brasília: IPEA, 1997. p.1-40 (Texto para discussão, 531)

WARNKEN, P. Política e programas para o setor de soja no Brasil. Revista de Política Agrícola, v.7, n.2, p.18-31, 1999. 